\title{
Константин Вагинов
}

\section{Собрание стихотворений}

Verlag Otto Sagner München · Berlin - Washington D.C.

Digitalisiert im Rahmen der Kooperation mit dem DFG-Projekt „Digi20“

der Bayerischen Staatsbibliothek, München. OCR-Bearbeitung und Erstellung des eBooks durch den Verlag Otto Sagner:

http://verlag.kubon-sagner.de

() bei Verlag Otto Sagner. Eine Verwertung oder Weitergabe der Texte und Abbildungen, insbesondere durch Vervielfältigung, ist ohne vorherige schriftliche Genehmigung des Verlages unzulässig.

«Verlag Otto Sagner» ist ein Imprint der Kubon \& Sagner Emmbht 


\title{
ARBEITEN UND TEXTE ZUR SLAVISTIK · 26 HERAUSGEGEBEN VON WOLFGANG KASACK
}

\author{
Константин Bатинов
}

C O

Составление, послесловие и примечания Леонида Черткова

Предисловие В. Казака

1982

München Verlag Otto Sagner in Kommission 
$z 76.1431(26$

Der Leningrader, heute in Paris lebende Philologe Leonid čertkov gibt mit dieser Edition die erste Sammlung aller bis jetzt erreichbaren Gedichte vion Konstantin Vaginov (1899 - 1934) - zeitweise Mitglied der Gruppen "Cech proetov", "Ostrovitjane", "Oberiu" - textkritisch heraus. In der Sowjetunion: ist nach seinem Tode kein Band aufgelegt worden. - Ich danke Leonid Črtkov fiür diesen Beitrag zur slavistischen Forschung, Frau Dr. Irmgard Lorenz für redaktionelle Mitarbeit und dem Verein der Freunde und Forderer der Univers:ităt zu köln für finanzielle Unterstutzung.

W..:K.

CIP-Kurztitelaufnahme der Deutschen Bibliothek

Vaginov, Konstantin:

Sobranie stichotvorenij / Konstantin Vaginov. Sostavlenie, poslesl. i primeč. Leonida Čertkova. Predisl. V. Kazaka. - München: Sagner, 1982. (Arbeiten und Texte zur Slavistik; 26) ISBN 3-87690-157-X

NE: GT

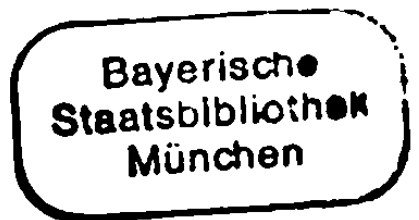

Als Manuskript vervielfaltigt

Alle Rechte vorbehalten

ISSN 0173-2307

ISBN $3-87690-157-x$

Gesamtherstellung Walter Kleikamp • Köln 


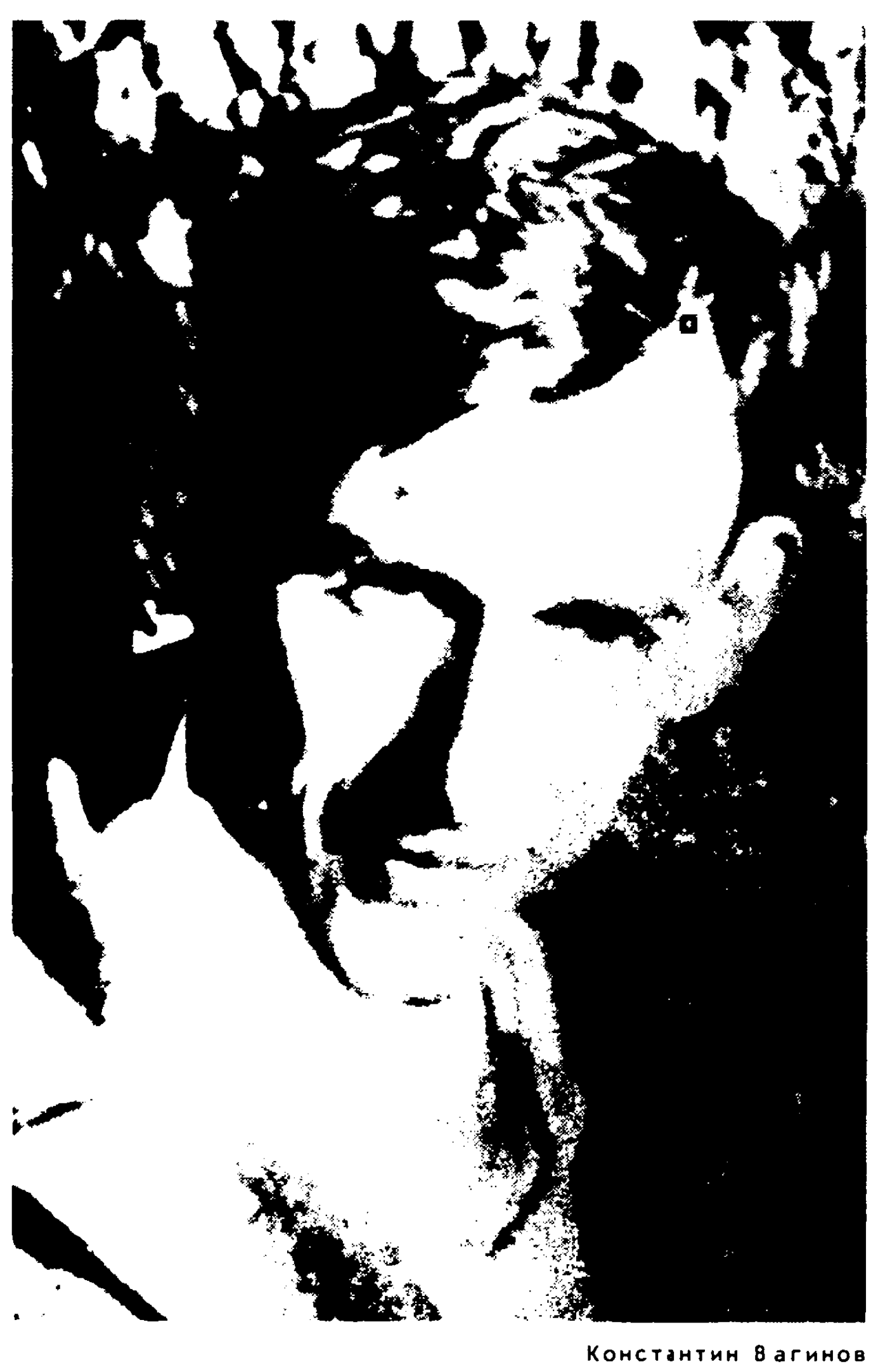


К заслугам Леонида Черткова принадлежит то, что он вместе с Т. Никольской в 1967 . в альманахе "День поззии"l впервые после более чем трех десятилетий обратил внимание в самостоятельной статье на творчество Константина Константиновича Baгинова (1899-1934). Имя Вагинова не приводится ни в первом томе "Краткой литературной энииклопедии" (1962) ни в историях литературы Академии наук СССР², ни в пособиях по литературе, допущенных Министерством высшего и среднего специального образования СССР". В 1960 г. Лияия Чуковская в своей книге "В лаборатории редактора" хотя и коснулась обходимой молчанием группы обзриу (Хармс, Введенский) 4 , однако имя забытого вагинова, несмотря на то, что оно упоминается в манифесте 0бзриу, она оставила без внимания. Оаин из последних очевидчев группы 0бзриу Исай Аркаяьевич Рахтанов включил в $1962 r$. в сBою стать⿰ о детских журналах "Eж" и "чиж" одну Фразу - 8arинове 5 , ленинградский литературовед Анатолий Александров, один из первых советских исследователей творчества обзриутов упомянул в 1966 r. ero Фамилиш в статье оH. A. Заболоцком ${ }^{6}$ в 1968 . B журнале "Československá rusistika"7 более подробно писал о нем, доказывая, что вагинов был близок к обзриутам скореекак прозаик, чем как позт. Одновременно с выходом альманаха "День поззии" (1967) T. Никольская выступила на XXII научной студенческой конференции в Tарту с докладом о Baгинове 8 , однако в наиболее доступной Форме она осветила его жизнь и творчество в дополнительном томе (1978) к "Краткой литературной знциклопедии"9.

После ранней смерти Вагинова в $1934 \mathrm{r}$. в Советском Cокзе не переиздавался ни один из его трех сборников стихов, напечатанных в 1921-31 rг., ни один из его романов. После того как Л. Чертков и Т. Никольская обратили внимание на произведения вагинова, некоторые из них были переизданы в 1967 . на Западе. Карл Проффер выпустил стереотипное переиздание первого сборника лирической поззии ватинова ${ }^{10}$, Ррий Иваск и X. В. Тьялсма вкличили восемь стихотворений Вагинова в "Антологию Петербургской поззии акмеизма" (1973) 11 , 0. Малмстеа и Т. Шмаков поместили большую часть неопубликованного иикла "Звукоподобие" в пространном парижском альманахе "Aполпон 77 "12, и в 1978 r. появилось еще одно стереотипное издание в Сша 13 . B справочниках имя вагинова засвидетельствовано впервые в 1976 . 14. 
Леония Чертков, составивший предлагаемое первое комментированное издание всех доступных стихотворений Вагинова, имел возможность сверить большинство из них с рукописным подлинником. Сборник "ППутешествие в хаос" (1921, переиздание 1972) он пополнил пятьк до сих пор неопубликованными, однако предусмотренными аля него стихотворениями. Сборник "Петербургские ночи", который должен был выйти в $1924 \mathrm{r}$. , Черткову не удалось восстановить полностьо. в челом в него должно было войти 50 стихотворений, 12 из них печатаются здесь впер вые, 20 собраны из разных изданний (два из сборника без названия, Ленинграя 1926, переиздание 1978), а 18 приходится пока сиитать про павшими. Чертков впервые собрал все стихотворения, возникшие в 192030 rr., которые Вагинов не включил ни в один из своих ииклов. 16 из зтих 31 стихотворения, и позма "1925" в 11 странии, печатартСя здесь впервые. Спустя 50 лет Иертков в зтом сборнике вновь открывает читателям доступ к последнему, опубликованному в $1931 \mathrm{r}$. сборнику стихотворений вагинова "Опыты соединения слов посредством ритма". В него входит приблизительно половина стихотворений из сборника без названия (1926), отчасти в несколько иных редакииях. Готовя к изданию цикл "Звукоподобие", Чертков токе пользовался рукописным оригиналом, благодаря чему ему удалось избежать ошибок, имеющихся в альманахе "Aполлон $77^{\prime \prime}$ и увеличить на два число напечатанных в ней стихотворений. В примечаниях дана подробная справка о первом издании стихотворений и различных их версиях.

Что касается литературы о вагинове, то пои его жизни о нем положительно высказались такие известные писатели, как Адамович, Брксов, Ходасевич, Гоуздев, Гумилев, Луни, Оиуп и В. Рождественский. в своем послесловии Чертков приводит много иенных иитат из почти недоступной литературы о Barинове. В 1930 r. Barинов вместе с такими авторами, как B. Катаев, Л. Борисов и D. Берзин подвергся нападкам за "бесиветную литературно-идеологическуо позииир"15 с своем романе "Труды и дни Свистонова". Уже в 1933 . eго стихотворения сиитались всего лишь "искусным "слепком" с образиов буржуазного позтического мастерства"16. Одновременно с попнткой Т. Никольской и Л. Черткова в 1967 r. вклюиить зтого обходимого молчанием автора в русскуо литературу леония Борисов иитирует в автобиографических воспоминаниях о нем (прежде всего как книтолюба) стихотворение "За ночьо ночь"l. Вслед за ними А. македонов в $1968 \mathrm{r}$. 
в своей кните о Николае заболоцком в связи с Н. Тихоновым положительно оценил вагинова (как члена группы "Островитяне" в начале нэпа) и как обэриута, которому "игра введенского и хармса в бессмыслинку была несвойственна"18.

Исходя в своей лирике из символизма и акмеизма и пройдя путь от "цеха позтов" Гумилева до преемников Футуризма в группе обзриу, Константин 8агинов представляет собой своеобразное явление в русской поззии.Надерсь, что зтот сборник, Содержащий всю доступнуо лирику поэта, внесет вклад в то, чтобы вагинов вновь занял место в истории русской литературш.

Благодарю господина Леонида Черткова (Париж) за издание сборника и послесловие к нему, Фрау А-р Ирмгара Лоренц (Кельн) за содействие при редакиионн й работе и общество друзей Кельнского университета за Финансову⿰ подаержку.

Кельн, иоль 1982 года Wolfgang Kasack

'Т. Никольская, Л. Чертков, "Константин Вагинов". В с6.: "День поззии". Ленинград 1967, с. 77-79.

2"История русской советской литературы" I-IIL РеА.: А.Г. Дементьев, Л.И. Тимофеев. Москва: иза-во АНСССР 1958-1961; 2-е изд., испр. и Aоп. I-IV. PeA.: A. Г. Аементьев, Л.М. Поляк, Л.И. Тимофеев. Москва: изд-во Наука 1967-1971.

З"История русской советской литературы" I-II. РеА.: А.И. Метченко, Л.М. Поляк, Л.И. Тимофеев. Москва: изд-во Московского университета 1958-1963; "История русской советской литературы". Ред.: П.С. Выходцев. Москва: изд-во Высшая школа 1970; 2-е иза. 1974.

4л. Чуковская, "В лаборатории редактора". Москва: изд-во Искусство 1960. 0 A.И. Хармсе: сс. $211,223,257,258,259,294,300$; О А.И. Введенском: сС. 211, $223,257,258,260-263,264,294,310 ; 2-$ е изд. 1963. 0 Хармсе: сс. 221, 232, $268,269-270,311,316$; о введенском: сс. 221, 232, 268, 269, 271-274, 275,311 , 330 .

5И.А. Рахтанов, "Еж' и 'Чиж'". В кн.: "На широтах времени". Москва: Советский писатель 1973, сс.389-423 (399).

6А. Александров, "Заметки о книге стихотворений Николая Заболоцкого". В журн.: "Звезда" 1966.10. сс. 211-217 (212).

7 он же, "Обэриу. Предварительные заметки". В журн.: "Ceskoslovenská rusistika" XIII (1968) 5, cc. 296-303 (300-301).

${ }^{8}$ т. Никольская, "О творчестве К. Вагинова". В сб.: "Материалы XXII научной студенческой конферениии'". Ч. 1. Тарту 1967.

9 Краткая литературная знциклопедия 9. Москва: изд-во Советская Энциклопедия 1978 , c. 169. 
10К. Вагинов, "Путешествие в хаос". Петербург 1921. Fadsimile Edition by Ardis, Ann Arbor 1972.

"1"Антология Петербургской поззии зпохи акмеизма. Acmeists and others: An Anthology". Edited with an Introduction and Notes by George Ivask and H.W. Tjalsma. München: Wilhelm Fink-Verlag 1973, cc.164168 (Centrifuga 16).

12 А. Малмстед, Г. ШМмаков, "Константин 8агинов". В сб.: "Аполлон-77". Ред. М. Шемякин. Париж 1977, сС. 34-41.

13К. Вагинов, [Стихи, посвященные А. Федоровой]. Ленинград 1926. Reprint by Ardis, Ann Arbor 1978 .

14 wolfgang Kasack, "Lexikon der russischen Literatur ab 1917", Stuttgart: Kröner-Verlag 1976, S. 415-416.

15р. Mесcер, "Попутиики второго призыва". В журн.: "Звезда" 1930.4. сс. 203-211 (207).

16и. Оксенов, "Борьба за лирику". В журн.: "Новый мир" 1933.7/8. сс. 399407 (401).

17 Л. борисов, "Родители, наставники, позты". Москва: иза-во Книга 1967. cc. 87-89.

18 А. Македонов, "Николай Заболоикий". Ленинград: Советский писатель 1968. c. 45 . 


\section{COAEPXAHИE}

По поводу первого собрания стихотворений Константина Вагинова

Предисловие В. Казака

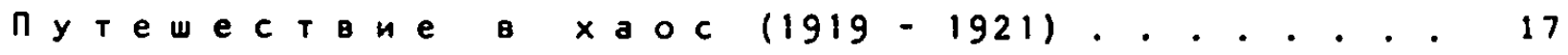

Седой mабун из вихревах сmепей . . . . . . . . . . . . . . . . 18

Euе зари оракхевое рханое . . . • . . • . . . . • . . . . . 19

Под пегим городом заря играла в труба . . . . . . . . • . . . . 20

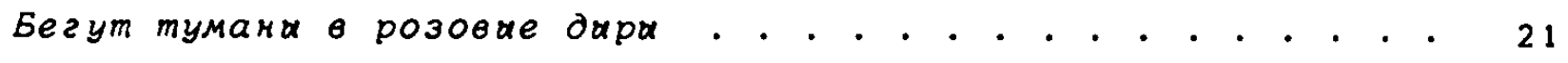

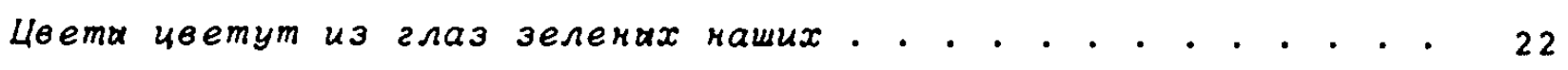

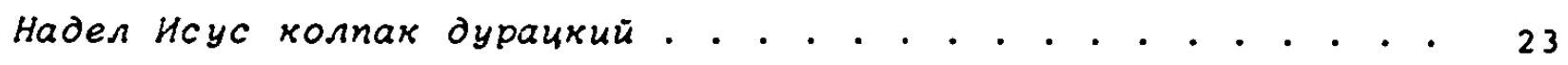

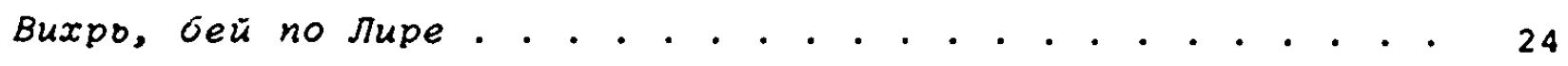

Набухнут бубка звезд кад нами . . . . • . . . . . . . . . . 25

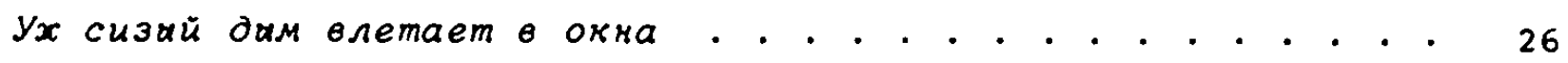

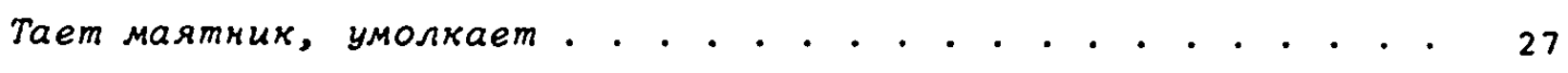

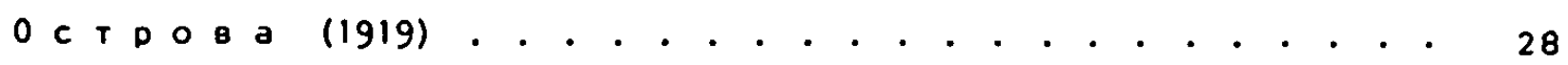

O, уоалиюся на острова Еарохдений . . . . . . . . . . . . . 28

Как нехек запах твоих ладокей . . . . . . . . . . . . . . . 29

Сегодкя - дара, ке зрачки у глаз . . . . . . . . . . . . . . 30

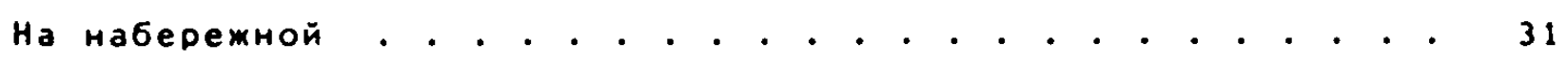

В стариянах запахах, где золото и Gархат . . . . . . . . . . 32

Луна, как глаз, калиласо кровох . . . . . . . . . . . . . . 33

Eсто страякае ковра, где лияии неяска . . . . . . . . . . . 34

КаФз в переулке • • • • • • • • • • • • • • • • • • • • • • 35

Ma здесо вдали от сугробов. . . . . . . . . . . . . . . . . . . 37

Ha nалубах Летучего Голландиа . . . . . . . . . . . . . . . 38

умолккет ли проклятая шармакка? . . . . . . . . . . . . . . 39

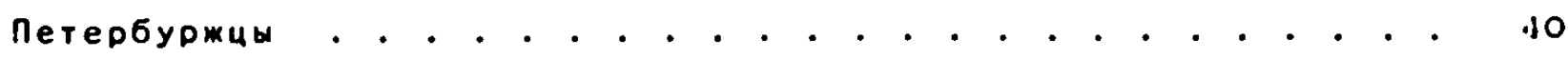

за осоку, за лед, за скега. . . . . . . . . . . . . . . . . 41

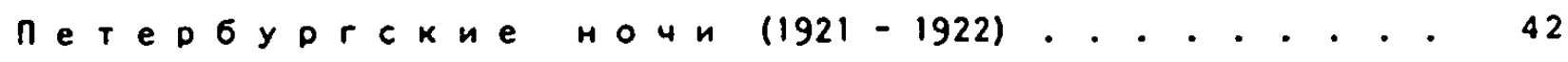

Перевернул глаза и осмотрелся . . . . . . . . . . . . . . . . 43

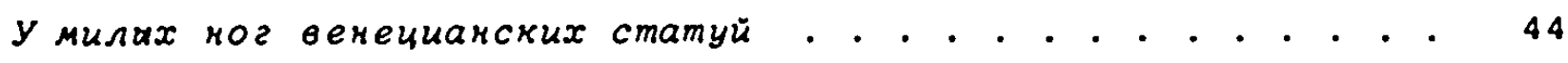

C Aнтиохией в палоие шел по уличе . . . . . . . . . . . . . . 45

намалия сердие - пусто не болоко будет . . . . . . . . . . . 46

Кахдай палеи мой - исчезнуеший город . . . . . . . . . . . . 47 
Cпит в реснииах твоих золоченах . . . . . . . . . . . . . . 48

упала ночо в төои реснииа . . . . . . . . . . . . . . . . . 49

Покрал, прикрал и вново покрал собо: . . . . . . . . . . . 50

Oпято у окон зов мадагаскара . . . . . . . . . . . . . . . 51

Камин горит на площади огромной. . . . . . . . . . . . . . 52

один бреду среди рогов урала . . . . . . . . . . . . . . . 53

В нагорних горнах гул и гул, и гром . . . . . . . . . . . . 54

Любово опято томит, весеняий запах нехен . . . . . . . . . 55

И умер он не при луне иервонной . . . . . . . . . . . . . . 56

Двенадиато долгих дней в груди махало сердие . . . . . . . 57

$Я$ ecman, nоuативаясо, u nошел nо стенке . . . . . . . . . . 58

Палеи мой сияет зөездой вифлеема . . . . . . . . . . . . . 59

Чернеет ночо в моей руке подзятой . . . . . . . . . . . . . 60

темнеет море и пливет корабло . . . . . . . . . . . . . . . 61

Buшел ча Kарповку зөезди сиитать . . . . . . . . . . . . . 62

B пернатах облаках все те хе струна слава . . . . . . . . . 63

Петербургский звездочет . . . . . . . . . . . . . . . . . . . 64

Стали улииа узкими после грохота солниа . . . . . . . . . . 66

Все хе я люблю холодние халкие звезди. . . . . . . . . . . 67

Помно последнюо ночо ө доме покойного детства . . . . . . . 68

Санам Неви не сөергкуто ига өласти . . . . . . . . . . . . . 69

Нет, не любль закат. Пойдемте далоще, Лида . . . . . . . . 70

Жив отшелоником Екатерининский канал 105. . . . . . . . . 71

усталосто в теле бродит плоскоспями . . . . . . . . . . . . 72

мой бог гнилой, но оносто сохранил . . . . . . . . . . . . 73

Н все $x$ я не хивой под кущей Аполлона. . . . . . . . . . . . 74

И голай я стол среди скегов. . . . . . . . . . . . . . . . 75

С тихотворения $1920-1930^{\circ}$. . . . . . . . . . . . . 76

Под рохою спит спокойно лампа Аладина . . . . . . . . . . . 77

Пливут ө тарелке оттоманские фелюги . . . . . . . . . . . . 78

О, заверни в конфетную бумахку . . . . . . . . . . . . . . 79

Сидит она, торгуя на дороге . . . . . . . . . . . . . . . . 8

Бегу в ночи над финскою дорогой . . . . . . . . . . . . . . 81

искусство . . . . . . . . . . . . . . . . . . . . . . . 82

А снял сапог и променял на звезда. . . . . . . . . . . . . 83

Я променял весо дивний гул природа . . . . . . . . . . . . 84 
Немного меда, перца и вервена. . . . . . . . . . . . . . 85

Лишо иумят в непогоду ставни . . . . . . . . . . . . . . . 86

Ночо отгорела оплавшей свечой восковой . . . . . . . . . . 87

Ви римскор дерхавной колесничей . . . . . . . . . . . . . . 88

Осапліт липа поедестал чугунний . . . . . . . . . . . . . . . 89

Не лунному, ко зөонкому поэту . . . . . . . . . . . . . . . 89

Ma запада последние осколки . . . . . . . . . . . . . . . . 90

Ма рохдена для пишности для слава. . . . . . . . . . . . . 91

He пестрою, но радостной природой . . . . . . . . . . . . . 92

До белих барханов твоих . . . . . . . . . . . . . . . . . . 93

Но знал 8 , корабло спокоен . . . . . . . . . . . . . . . . 94

час от часу редеет мрак медвянай . . . . . . . . . . . . . 95

Пред разночветнох толпох . . . . . . . . . . . . . . . . . 96

Он думал: вот следа . . . . . . . . . . . . . . . . . . . . 97

Я стал просвечивающей формой . . . . . . . . . . . . . . . 98

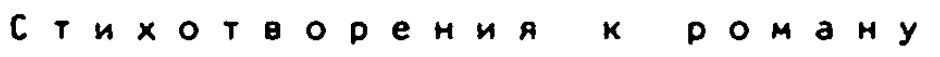

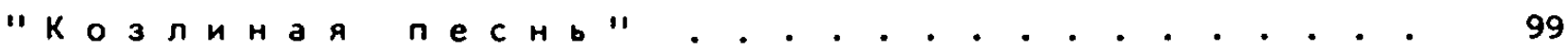

Весо мир пошел дрохащими кругами . . . . . . . . . . . . . 99

Ленинтрадская ночь . . . . . . . . . . . . . . . . . . . 100

Война и голод тоино сон . . . . . . . . . . . . . . . . . 102

Нам о коости өлоренция сияла . . . . . . . . . . . . . . . 103

C T И Х О T В D

" $r$ a na $r$ они а а а". . . . . . . . . . . . . . . . . . 104

Tают дома. Любово идет, хохочет... . . . . . . . . . . . 104

В тиии ночной. . . . . . . . . . . . . . . . . . . . . . 105

Украшение берегов. . . . . . . . . . . . . . . . . . . . 106

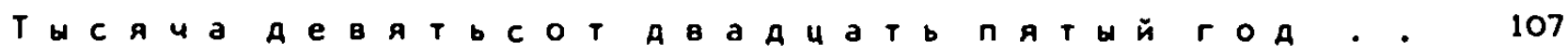

0 ก

ก $○$ C $P$ e A $C$ T

Поэма квадратов. . . . . . . . . . . . . . . . . . . . . 120

Любово страина не смертол почелуя . . . . . . . . . . . . . 122

Среди ночнах о́листателонах блухданий . . . . . . . . . . . 123

Шумит Родос, не спит Александрия . . . . . . . . . . . . . 124

Я полобил широкие каменоя . . . . . . . . . . . . . . . . . 125

В селеноях городских, где протекала оносто . . . . . . . . 126

Крутам баком пересекая стена . . . . . . . . . . . . . . . 127 
У труи́нах горл, под сенол гулкой ночи . . . . . . . . . . 128

4 пестрой хизно моя бала. . . . . . . . . . . . . . . . . 129

Не человек: все отошло и ясно . . . . . . . . . . . . . . 130

Я воплотил унавнай голос ночи . . . . . . . . . . . . . . 131

один средо мгла, среди домов ветвистах . . . . . . . . . . 132

Под гром война тот гробнай тато . . . . . . . . . . . . . . 133

во́лизи от войн, в своих сквознах хоромах . . . . . . . . . 134

H лирник спит в проснувшемся приморое . . . . . . . . . . 135

Как хорошо под кипарисами люојови . . . . . . . . . . . . . 136

Психея (Спить брачный пир) . . . . . . . . . . . . . . . . 137

О, сделай статуей звенящей . . . . . . . . . . . . . . . . 138

Нз хеновиднх слов змеей струятся строки . . . . . . . . . 139

Под лихолетоем одичалам . . . . . . . . . . . . . . . . . 140

В одехде из стариняах слов . . . . . . . . . . . . . . . . 141

Поззия есто дар в темниие ночи струнной . . . . . . . . . 142

отшельники . . . . . . . . . . . . . . . . . . . . . . . 143

одно неровное мгновеное . . . . . . . . . . . . . . . 146

Анахарзис . . . . . . . . . . . . . . . . . . . . . 147

Не тщисо, худохник, $к$ совершенству. . . . . . . . . . . . 148

О, сколоко лет в превращался в эхо................. . . 149

Да, иелий год я взвешивал . . . . . . . . . . . . . . . . 150

Ворон . . . . . . . . . . . . . . . . . . . . . . . 152

На кришке гроба Прокна . . . . . . . . . . . . . . . . . . 153

И снова мне мерещиласо любово . . . . . . . . . . . . .

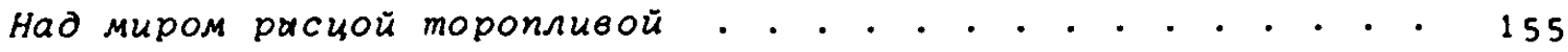

в стремящейся стране, ө определеняий час . . . . . . . . . 156

Эврияика . . . . . . . . . . . . . . . . . . . . . . . 157

Психея (Любовь, это вечная оность) . . . . . . . . . . . . 158

Тесе примерещился город . . . . . . . . . . . . . . . . . 159

Я восполненоя ке искал . . . . . . . . . . . . . . . . . . 160

Ночь. . . . . . . . . . . . . . . . . . . . . . . . . 161

Музыка . . . . . . . . . . . . . . . . . . . . . . . . . . 162

3а ночох ночо nycmo onadaem . . . . . . . . . . . . . . . 163

Деа пестрах одеяла. . . . . . . . . . . . . . . . . . . .

Эллинисты . . . . . . . . . . . . . . . . . . . . . . 166

мрак побелел, оледнели лииа . . . . . . . . . . . . . . . 167

Om берегов на берег . . . . . . . . . . . . . . . . . . . 168 
Не лазоревай дохдо . . . . . . . . . . . . . . . . . . . . . 169

Дрохал проспект, стреляя светом. . . . . . . . . . . . . 170

П есня с пов . . . . . . . . . . . . . . . . . . . . . 171

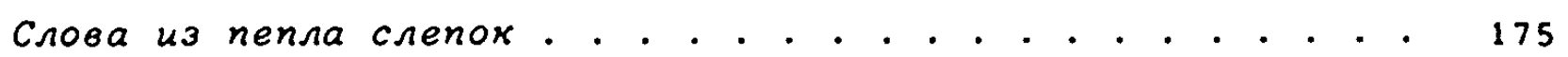

3 в ук०пОАОбие . . . . . . . . . . . . . . . . . 176

Черно бесконечное утро . . . . . . . . . . . . . . . . . . 177

Hem, не расстался \& с moбор . . . . . . . . . . . . . . . . 178

Ночное пьянство . . . . . . . . . . . . . . . . . . . 179

ronoc. . . . . . . . . . . . . . . . . . . . . . . . . . 181

Психея дивная. . . . . . . . . . . . . . . . . . . 182

нариисс . . . . . . . . . . . . . . . . . . . . . 183

золотие глаза. . . . . . . . . . . . . . . . . . . . . . 184

Всю кочо дома дишали светом . . . . . . . . . . . . . . . . 185

На наберехной рассвет. . . . . . . . . . . . . . . . . . 186

Русалка пела, дичо хдала . . . . . . . . . . . . . . . . . 187

он с оностол сөоей, как долхно, распрочался . . . . . . . . 188

Пред Революиией громадной . . . . . . . . . . . . . . . . . 189

Когда ускули все опято . . . . . . . . . . . . . . . . . . 190

Кентаврами восходят поколекоя . . . . . . . . . . . . . . . 191

Он разлюбил себя, он вишел в непогоду . . . . . . . . . . . 192

Прехрасен мир ке в прозе полудикой . . . . . . . . . . . . 193

в повашеняом горе . . . . . . . . . . . . . . . . . . . . . 194

Кахою прихотоп глупейщей . . . . . . . . . . . . . . . . . 195

Хотел он, превращаясо в өолка. . . . . . . . . . . . . . 196

ух деко краскеет, точно нос . . . . . . . . . . . . . . . . 197

Он с кахдам годом уменошался . . . . . . . . . . . . . . . 198

"Как хало", - подумалосо ему . . . . . . . . . . . . . . . 199

За годом год, как листоя под ногор . . . . . . . . . . . . 200

Баллада . . . . . . . . . . . . . . . . . . . . . . 201

Почуествовал он Боль, в поток людей глядя. . . . . . . . . 202

Ожная ночь. . . . . . . . . . . . . . . . . . . . . . . . 203

Подделки окую любово напоминают . . . . . . . . . . . . . . 204

Норд-ост гяул паломх, муимулу, маслика . . . . . . . . . . . 205

вступил в Краму в зеркалокуо прохладу . . . . . . . . . . . 206

Ленинтрая . . . . . . . . . . . . . . . . . . . . . 207

В аду прекраскае селеноя. . . . . . . . . . . . . . . . 208 
Поззия Константина Вагинова

(Послесловие Л. Черткова)

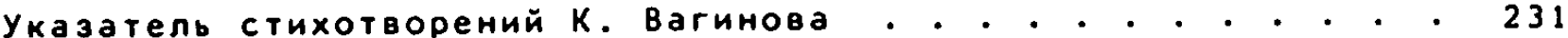


ПУTEUECTBИE $B$ XAOC

$(1919-1921)$

Достохвалокому Aббатству Гаэров посеяuaem cooe nymeшествие Нокстактия Вагиков 
Сеяой табун из вихревых степей

Промчался все круша и руша.

И серый mox покрыл стада камней.

Травой зеленой всходят наши Ауши.

Муот траву стада камней.

В ночи я слшшу шорох жуткий,

И при большой оранжевой Луне

Уходят в камни наши Ауши. 
Eще зари оранжевое ржанье

Eрусалимских стен не потрясло, Лицо Иоконоанна - бельй камень

Цветами зелени и глины поросло.

И голова моя качается как череп 5

У Окон СИзнх, У пустнх домов

И в пустшри открытн двери,

ГАе щебень, вихрь, круженье облаков. 


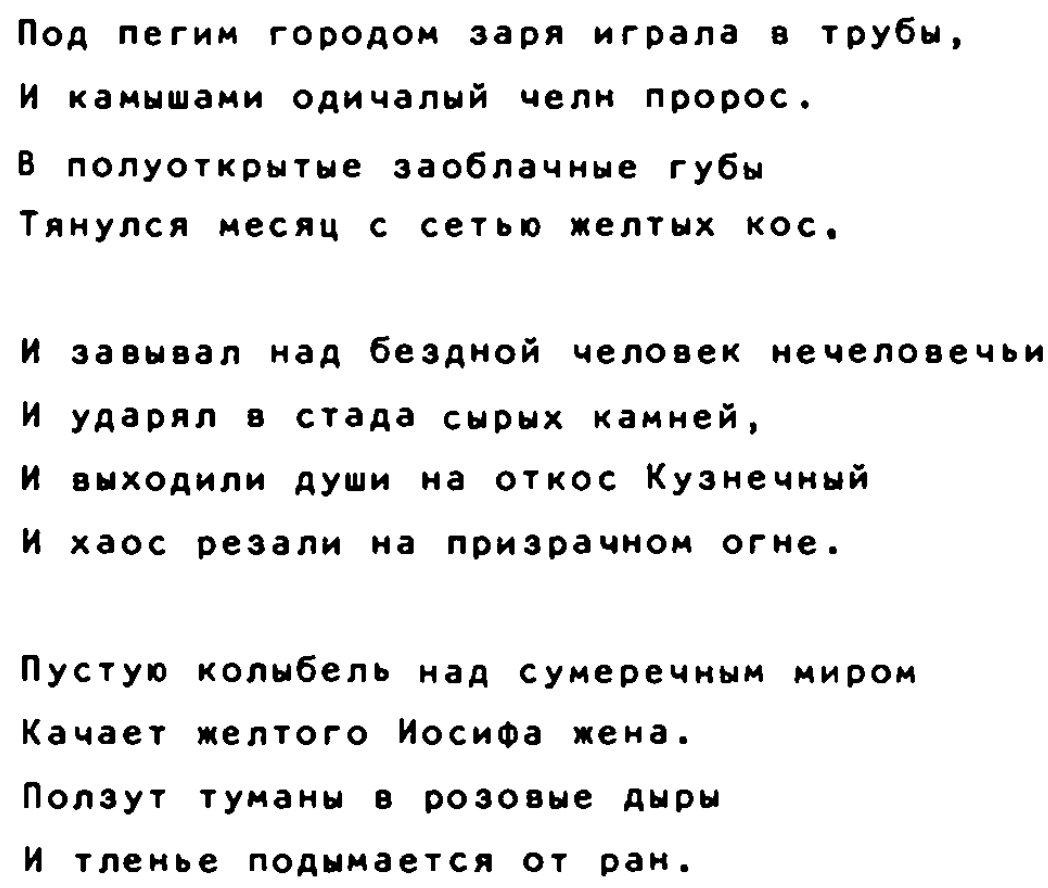


Бегут туманы в розовне Анры

И золоченых статуй в них мелькает блик,

Маяк давно ослеп над нашер квартирой

3 а бахромой ресниц - истлевшие угли.

Apan! Сарвай скореe карты!

Нам Каждому Приходится ночной Кусок,

Заря уже Аавно в окно покашливает

И внставляет солнечний сосок.

Сосите, мол, и уходите в камни

Вы что-то засиделись за столом,

и в norpemyшках вся,мария в ресторане

o cymacueawem cuнe aymaet cвoеm. 
Цветы иветут из глаз зеленых наших

И наши мысли лепестки твердят,

Безумный Иисус с виновног ромашкой

Бредет куда глаза глядят.

0, только бы уйти от Бога,

Солгавего и лraвwero вcerá,

И месяц ржет на голубой дороге

И там вдали смеется Иораан. 
Надел Исус колпак Аурацкий,

Oзера сохли rлas Ero,

И С пиком, вшвшим из акаций,

Совокупился лик Ero.

Кусает солнче холм покатнй,

в крови листва, в крови песок...

И броаят овин межау статуй,

Hосами тынут в пальцы hor. 
Вихрь, бей по Лире,

Лира, волком вой,

Xаос все шире, шире...

Госпояи! Упокой. 
Набухнут бубны звезд ная нами,

Бубновой Аамой вийдет ночь,

И над великим рестораном

Прольет багряное вино.

И ты себя как rорсть червонцев,

Как тонкий меХ инАийских КОз,

0тдашы в eе rnyxoe лоно

И в нем задремлешь глубоко.

Прильни овалом губ холодных

Последний раз к перстам чужим

И в человеческих ладонях

Почувствуй трепетанье ржи.

Т вой АОМ ОКном ГЛядит в Пространство,

Cuporo лона sanax в нем,

Как Финикия в вечность канет

Ero Арийское веретено. 
Уж сизый дым влетает в окна,

Простертий на диване труп

8 се ищет взорами волокно

Хрустальных дней развятуо игру.

И тихий свет над колшбельо,

Koraа рождался отошеАший мир,

Тогда еще Авроры трубы пели

И у бубновой дамы не было восьми. 
Тает маятник, умолкает

И останавливартся часы.

Xaoc - apan c rлyхих окраин

Картн Аержит, КаК человеческий Снн.

Сало бубновуо ааму и доволен,

Даже нет желанья играть,

И ХрУСтальн世й Звон КОЛОкоЛЬн世й

Бежит К КОЛОКОЛЬням Вспять. 
OCTPOBA

(1919)

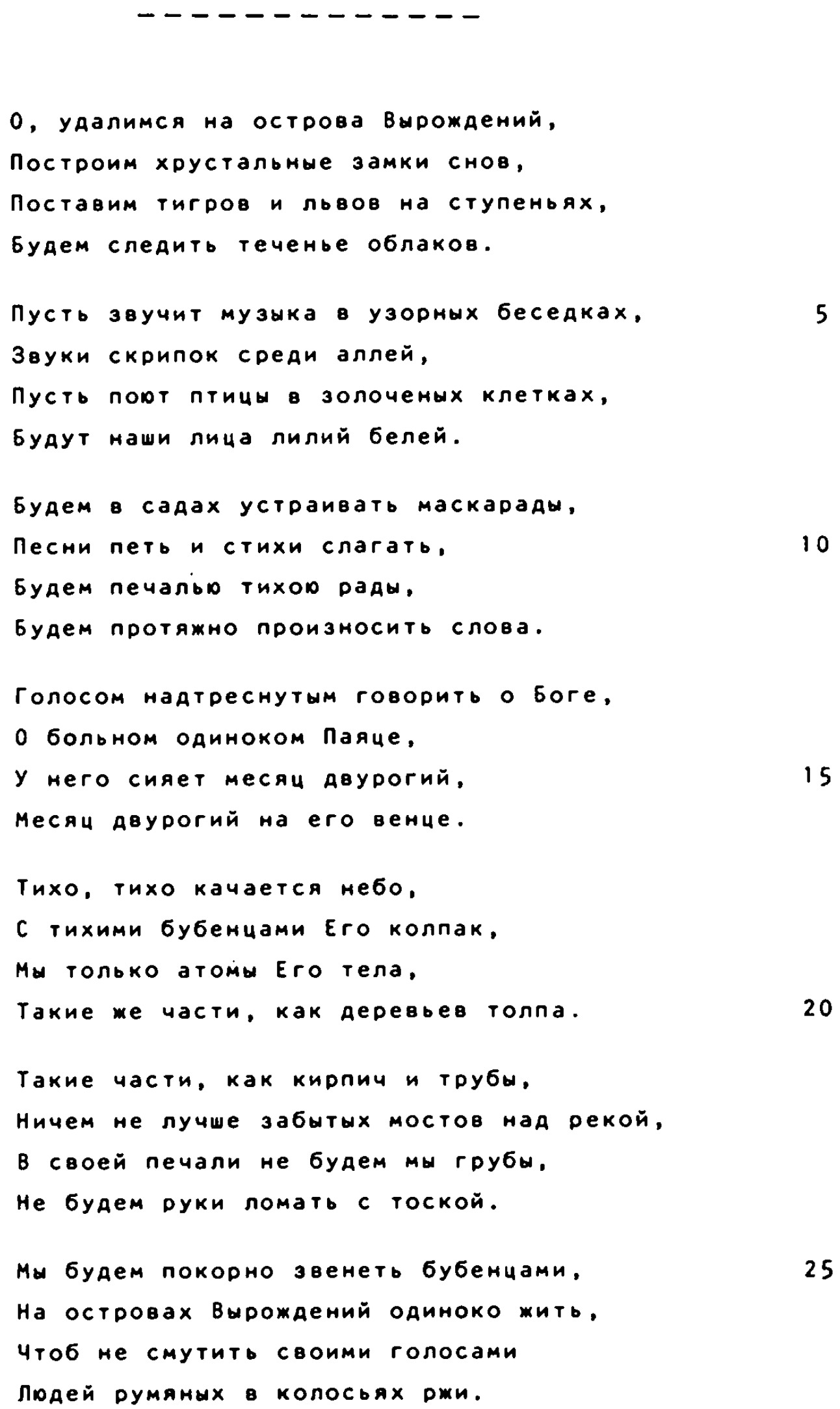


Как немен запах твоих ладоней, Mорем и солнцем пахнут они,

КолокоЛЬным тиХим Звоном ПоЛный

Лаяоней корабль бортами звенит.

Твои предки возили пряности с Явы,

C голубых островов горячих морей,

Помнишь кусочек якоря ржавый

Хранится в узорной шкатулке твоей.

Там же лемат венецианские бусы

И золотые монеты с Марком святым,

умер корабль, исчезли матросы,

волна не быртся в его борты.

Oн стал призраком твокх лаяоней,

Бросил якорь в тоей крови,

И погребальным звоном полны

маленькие нежные руки твои. 
Сегодня - Анры, не зрачки у глаз,

Как холоден твой лик, проплаканы ресницы,

Валли опять адмиралтейская игла

Заблещет,блещет в утренней зарнице.

И может бЫть, ночной ОГРОМный крик

Был только маревом на обулыжненном болоте,

и стая не слетится черных птиц,

И будем слышать мы орлиный клекот... 
Как беАр твоих волнует острие.

Еще распущены девические косы,

Koraа зубов белерщих копье

Пронзает губы алые матросов.

На набережной, где снуот они,

С застывшей сольр на открытых блузах,

Ты часто смотришь на пурпурные огни

На черных стран чветные грузы.

В твоей руке колода старых карт,

Закат горит послеяними углями,

Инаийских гор зеленая река

Уснет в тебе под нашими снетами.

И может бUть сетодня в эту ночь

Услышу я ее больные зовы,

КогАа от кораблей пойдем мы прочь

B ворота ПоА ФОнарь багровнй. 


\begin{abstract}
В старинных запахах, где золото и бархат
в бассейнах томности ласкарт ноздри вам, растут левкои белые у золоченых арок,

h mope nypnypom сжимает 6epera.
\end{abstract}

Среди жеманных, еле слышных звуков,

Там жизнь течет подобно сладким снам.

Какой-то паж целует нежно руки

$h$ розы тянутся к эмалевым губам.

в квадрат очерчены цветочные аллеи,

в овалы налиты прохлаяные пруды,

И очертание луны серпом белеет

Hа зеркалах мериаюиих воды.

в старинных запахах, гяе золото и бархат,

в бассейнах томности ласкает ноздри вам,

вы встретите себя. у золоченых арок

держащей белого козленка за pora. 
Луна, как глаз, налилась кровьо,

Повисла шаром в темноте небес,

И возаух испешрен мычанием коровьим,

и воливим завываньем полон лес.

И старый шут горбатый и зеленый

Из иарских комнат прибежал к реке

И телом обезьянки обнаженным

грозил кому-то в небесах в тоске.

h наверху, тае плачут серафимы,

Звенели колокольиш колпака,

И старый 亏ог, огромный и незримый,

спектакль смотрел больного червяка.

И шут упал и ангелы молились,

Заплаканные ангелы у трона Паяца,

А Он В сияньи золотистой пыли

Смеялся резким звонам бубениа.

И век за веком плшл своей орбитой,

рояились юноши с печальо вместо глаз,

С Аушов обезьянки, У реки убитой,

И с той поры ияет о Паяче рассказ. 
Есть странные ковры, где линии неясны,

Гае краски прихотливы и нежны,

Персияский кот, челуя вашу грудь прекраснуо,

Hапоминает мне под омным небом сны.

Цветн свой аромат Аарят прохладе ночи,

Дарите ласки Вы персидскому коту,

Зеленый изумруд - его живые очи,

Зеленый изумруд баркает мечту.

Быть момет, это прини из сказки грезы лунной,

Быть монет, он в Кафтан волшебный облачен,

Звучат аля Вас любви восточной струны,

и принц персияский Вами увлечен.

Луна звучит, луна поет Вам серенаду,

Вам солнца ненавистен яркий свет,

Средь винных чар, средь гроздй виноградных

Ваш принц в волшебный мех одет.

Ковры персияские всегда всегда неясны,

Ковры персияские всегда всегда нежны.

Персияский принц иль кот? - Лобовь всегаa прекрасна.

Мш подчиняемся влиянир луны. 
Есть странные каФз, гАе лица слишком бледны,

Гае взоры странны, губы же ярки,

ГАе посетители походкоD неверной

0бхояят столики, смотря на потолки.

Они оборваны, Авиженья их нелепн,

Зрачки расширены их бегарщих глаз,

И Потолки их давят точно стены склепа,

Светильня Грустная аля них ФОнарний газ.

ОАИн в углу сияит и шевелит губами:

"Я новнй Бог, пришел, чтоб этот мир спасти,

Сказать, ито солнце в нас,ито солние не над нами,

पто каждый - Бог, что в каждом - все пути,

Что в каждом - Города, и рощи, и долины,

Что в каждом существе - $и$ реки, и моря,

Высокие хребты, И горнше низины,

Прозрачнще ручьи, Что золотит заря.

0 , мир весь в нас, мы сами - боги,

В себе построили из камня Города

И насаяили травы, провели дороги,

И путешествуем в себе мы целше года ...

Ho вот умолкла скрипка на эстраде

И новнй Бо лепечет - это только Сон,

И муха плавает в шипучем лимонаде,

И неуверенно К Аверям ПОАХОАИт ОН.

Hа уличе стоит позт чугунный,

B саду итрает в мячик детвора,

И В небосклон далекий и лазурный

Пускает мальчик Ава шара. 
Есть странные каФэ, гАе лица слишком бледны,

Гае взоры странны, губы же ярки;

Там посетители походкою неверной

обходят столики, смотря на потолки.

1921 
Мы здесь вдали от сугробов,

От снежных метелей твоих,

Takoro веселья nonpoбуйте!

Hо нет нам путей других.

Оторванный ком не вернется,

Хотя бы ветер попутный был,

Oн только отчаянHо бъется,

растает, как дыма клубы.

Ничего, Нван, приготовьте

Мне сетодня новнй Фрак.

Почисти хорошенвко локоть,

- A как здоровье coбak?

А там Аалеко в cyrpo6ax,

Голодная, в корчах родов,

Россия колотится в гробе

СреAИ Аеревень, ГОродов. 
Hа палубах Летучего Голландца

Так много появилось крыс...

И старый капитан, обрызганный багрянцем,

напрасно вспоминал ветры...

И в капище у белой Аьяволицы

C рогами и младенцем на руках,

Hапрасно костяки молились,

Hanpacho светилась во впадинах тоска...

Ha пальцах высохших сверкали изумрудш,

И грызли призрачные ноги стаи крыс,

И кости издавапи запах трупный,

И были кости от прожорлившх мокры...

А там...на розовых архипелагах...

Среаи нетров с первобытным запахом зверей

Потомков развевались Флаги.

Вставало солнце на усеченной горе... 
Умолкнет ли проклятая шарманка?

И скоро ль в розах, белых и пречистых,

Наш милый брат среаи дорог лучистых

Пройдет с сестроп нашей обезьянкой?

Не знар я... Пути Господни - святы,

8 телах ме наших бубенин, не Ауши.

Стенать я буау с кажаым годом глуше:

Я так лобло Спасителя стигматы!

И нерез тод не оскорбло ни ветра,

Ни в поле ромь, ни в доме водоема,

Hи сераца девушки знакомой,

Ни светлого, классического метра... 


\section{ПЕTEРБУРXЦЫ}

Мы хмурые гости на чужаом Урале,

Мы вновь повернули тяжелые лиры свои:

Эх, Цезарь безносый всея Азиатской России

в Кремле Белокаменной с сытой сермагой, внемли.

Ородивых дом ты построил в стране белопушной

Под взвизги, Под взлеты, ПоА хохот кумачных знамен,

Земля необильна, земля неугодна,

Земла не нужна никому.

Мы помним наш город, Неву голубуя,

Медвяное солние, залив облаков,

Мы помним Петрополь и синие волны,

Балтийские волны и звон площадей.

Пов нами храпят широкие кони,

А рядом морава, черемисы и снет.

И мертвые степи, гае лихо летарт знамена,

Где пращуры встали, блестя, монгольской страны. 
3a ocoky, за лея, за chera,

В тихий дом позвала, где звенели стаканы.

и опять голубая в гранитах река

И сквозные дома и реянье ночи.

Эй, горбатый, тебя не исправит могила.

Голубуо Неву и сквозные дома

И ступени, где крысы грохочут хвостами,

в тихий дом ты привел за собой. 
ПETEPGYPTCKUE HOYH

$(1921-1922)$ 
Перевернул глаза и осмотрелся:

Внутри меня такой же черный снег,

Сутулая спина бескрылой птичей бьется,

В груди моей арожит и липнет свет.

И, освещенный весь, ияу я в дом знакомый

И, груаью плоскор облокотясь о стол,

Я ритмы меряю, выслушиваю звоны,

и муза голая мне руку подает. 
у милых ног венецианских статуй

Проплакать ночь, проплакать до утра

И выйти на Неву в туман, туман косматый,

rде ветер ржет и боет и скачет у костра.

Tабун, табун ветров копытами затопчет

Мой малый дом, мой тихий Петербург,

И Летний сад, и липовые почки

и залетевшую со Стрелки стрекозу. 
С Антиохией в пальче шел по уличе, Не видел Летний Сад,но видел водоем,

ПОА СИКОМОРОЙ КОНЬ И ВСаАНИК МНЛЯТСЯ

и пот скользит в луче густом.

Припал к ногам, целуя взгляа Гекаты,

Аостал немного благовоний и тоски,

Арап ЖАет рядом чернषй и Покатый

И вынимает Город из моей руки. 
Намылил сераце - пусть не больно будет

Поцеловал окно и трупом лег.

B руках моих песнь песней бродит,

o виноградной смуглости поет.

Eще есть жемчуга у черного Цейлона,

в Таити девушки желтее января,

Hо ветер за окном рекламу бвет и стонет,

Зовет тонуть в ночныX моряХ.

B соседнем доме свет зажгли вечерний,

Еще не верят в гибель синих аней,

Hо Apyr мой лижет руки нервно

И слушает, как умолкает сан во мгле. 
КажАЫй палец мой - ИСчезнувший ГОрОА,

А ладонь - океан тоски,

Может позтому так мне дороги

Pуки твои. 
Cпит в ресницах твоих золоченых

Мой старинншй умерший сая,

За ОКном МоИм ХОЯят Волн世,

Бури свист и звеза голоса,

Hо в ресницах твоих прохлада,

тихий вечер и шелест звезд.

Ничего, ито побит rрадом

3а окном огород из роз. 
упала ночь т тои ресницы,

Который Аень мы стережем любовь.

Антиохия спит, и синий Аым клубится

Среди иветных умерших берегов.

Орфей был человеком, я же сизым дымом.

Курчавой ночью тяжела любовь, -

Hе устеречь ее.0гонь неугасимый

Горит от этих мертвых берегов. 
Покрыл, Прикрыл И вновь покрыл собор

Небесный океан наш темный синий сая,

Но так же нежны у тебя ларони,

Hо так wе шелестят земные небеса.

Лобовь ТОМит меня огромной знойной птичей.

Ваыхать смогу ль я запах милых рук?

Haпрасно машут вновь твои ресницн,

Оаин останусь с птицей на ветру. 
Опять у окон зов Мадагаскара,

огромной птицей солнце вдаль летит,

Хожу ояин с зефиром у базара,

смешно и страшно нам без солнца жить.

Как странен лёт протяжных стран Европы,

Как страшен стук огромных звезд,

Но по плечу меня прохожий хлопнул -

Худой, больной и желтый, как Христос. 
Камин Горит на площаАИ огромной

И греет девушка свой побледневший лик.

Она бредет еврейкор бездомной

И рядом с нер шествует старик.

Крутись, сырая ночь, 8 eе глазах восточнах,

Старик, старик, куда ее ведешь?

Луна, Как червь, мой Подоконник точит,

Ужели завтра снова запоешь? 
Один бреду среди рогов Урала,

Гул городов умолк в груди моей,

Чернеют косы на плечах усталых,

Не отрекусь от гибели своей.

Давно ли ты, возлюбленная, пела,

Браслеты кораблей касались островов,

Но вот один оплакивах тело,

Но вот один бреду среди снегов. 
B наторных горнах гул и гул, и rрom,

Сквозь груды гор во Mихетах свечи светят,

Под облачным и пуховнм ковром

Глухую буро, свисти взвизги слышишь.

0 , та же гибель и для нас, мой Аруг,

0 , так же наш мохнатый дом потонет.

в широкой комнате, где книги и ковры,

Зеленой лампы свет уже не вздрогнет. 
Любовь опять томит, весенний запах нежен,

Кричала чайкой ночь и билась у окна,

hо тело с каждым днем становится все реже

И сквозь него синеет ИорАан.

И странен ангел мне, АОСчатый мост Аворчовый

и голубой как небо Петроград,

Когда сияет солние, светят скалы, горы

Из тела моето на зимний Летний Сая. 
И умер он не при луне червонной, He в тонких naлbuax золотых дорог,

Но там, гАе ходит сумрак желтый,

у деревянных и хрустящих гор.

0гонь Арожал над девой в сарафане

И ветер рвал кусок луны в окне,

А он все ждал,что шар плясать устанет,

Что все покроет мертвнй белнй снег.

Крутись же, карусель над синеш дорогой,

Подсолнечное семя осыпай,

Пусть спит под ним тяжелый, блудный ГОрОд,

Души моей старинный, черный рай. 
Авенадцать долтих дней в Груди махало сердче

И стало ГОродом Среаи Ливийских гор.

А Он все ходит по Садовой в церков

Ловить мой Успокоенный, остекленевший взор.

И стало страшно мне сидеть у белых статуй,

Вдыхать лазурь и пить вино из лоз,

Kогда он верит, Аруг и врат заклятый,

Что вновь пойду средь Павловских берез. 
я встал, пошатываясь, и пошел по стенке,

А Аполлон за мной, как тень, скользит,

Такой худой и с головою хлипкой,

И так протяжно нежно говорит:

"Мой Аруг, зачем ты взял кусок Зллады,

Зачем в гробу тревожишь тень мор?" -

Забился я поя злобным жестким взглядом,

Проснулся ранений, с сухой землей во рту.

Ни семени, ни шелкового зуда -

Не аля лобви пришел я в этот мир.

Мой милый друг, вдави глаза плечами

И обверни меня изгибом плеч твоих. 
Палец мой сияет звездой вифлеема,

в нем раскинулся сад, и ручей благовонный звенит,

и вошел Иисус и под смоквой плакучер аремлет

И на эллинской лире унылые песни твердит.

Обошел осторожно я АОМ, обреченный паденьо

отошел на двенадиать неровных, негулких шатов

И пошел по Сенной слушать звездное тленье

НаA застывшей водой чернокудрых снетов. 
Чернеет ночь в моей руке подвятой,

Душа повисла шаром на губах;

А лодка все бежит во ржи зеленоватой,

Пропахло рожью солние в облаках.

Что делать мне с моим умершим телом,

Зачем несусь я снова на восход;

Костер горел и были волны белы,

Зачем же дверь опять меня зовет?

Бреду по жести крыш и по оконным рамам,

Знакомый запах гнили и болот.

Ходил Аругой с своеш вечной дамой,

Ходил внизу и целовал ей рот. 
Tемнеет mope и плывет корабль

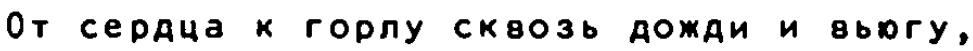

Но нет пути и пухнут якоря,

Горячим сургучом остеклянели губы.

Их не разьять, не выпустить корабль,

Матросы в шубах третий день не ели,

Hanpachо всходит глаз моих заря,

Напрасно пальчы броаят по сөирели. 
Bышел на Kapпoвку звезды сиитать

И аршином оглы широкуо осень измерить.

Я в тобетейке, на мне арестантский бушлат,

А за спинор луны перевитые песни.

Aруг мой студентом живет в малой Эстонской стране, 5

Взял балалайку рукой безобразной,

Тихо выводит и поет и ночи поет

и мигает затянутым пленкор глазом.

Знаю,там девушка с тающей грудьо как воск,

Знар,там солнце еще разудалой и милой Киприды, 10

НО зтст вечер Холодный, Тяжелый Как леА.

Перс мой товарищ И лейтенант Атлантиды.

Персне Поймет, только ГрУстно станет ему,

Вспомнит он сад И сермяжные волжские годн,

И лейтенант вскинет глаза в темноту

И услышит в домах голоса полосатого моря. 
в пернатых облаках все те же струны славы,

Амуров рой. Но пот холоднах глаз,

И пальиы помнят землю, смех и травы,

И серл зеленый у брегов Аубрав.

Умолкнул гул, повеяло прохлаяой,

Темнее ночи и желтей вина

Проклятый бог сухой и злой Эллады

На пристани остановил меня.

иоль 1921 
Анханьем Ливии наполнен Финский берет.

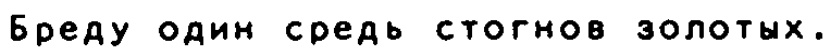

Со мнор шла чернее ночи Мэри,

С волнол губ во впадинах пустых.

В моем плече тяжелий ветер ашшет,

B monx rлазах готовит ложе ночb.

На небе пятый день Румяншй Нищий ищет,

КуАа Ушла его земная АОчь.

Но вот Авурогий глаз повис на небе иистом,

И в каждой комнате Проснулся звездочет.

Мой сумасшедший Аруг луну из монтекристо,

Как скрипку отзвеневшу⿰ убьет.

\section{2}

В Последний раз Аотронуться АО Облаков повщих,

Пусть с потолка тямелый снет ияет,

Пов хриплой кущей бархатистых кружев

Рнбак седой седуо песнь прядет.

Прядет Ли Он Аолины ИудеИ

Иль Аом крылатый на брегах Невн,

В груаи моей старинный ветер рАеет,

Качается И Ходит в ней ковыль.

НО Он сегодня вышел на дорогу,

И с Аевушкой пошел в мохнатый кабачок.

Он как живой, но тн его не трогай,

Oн ходит с ней по кошшам широко.

Шумит и воет в ветре Гала Петер

И девушка в Фруктовой слышит струны арФ,

А Звездочет опять прядет в своей карете

И наА Невой клубится синий звездный пар. 
Затем над ним, подъемля крест червонный, Качая ризой над чветным Ковром,

Священник скажет: - Умер раб Господний, Иван Петров лежит в гробу простом.

Мой дом двурогий дремлет на Эвроне

Псалмы Давида, мята и покой.

Но Аполлон в столовой ждет и ходит

Такой безглазый, бледный и родной.

4

Рябит рябины хруст под тонкой коркой неба,

А под глазами хруст покрытых пледом плеч,

А на руке браслет, а на коленях требник,

На голове чалма.0, если бы уснуть!

А Звездочет стоит безглазый и холодный,

Он выпил кровь мор, но не порозовел,

А аля меня лишь бром, затем приют Господень -

Четыре стороны в глазете на столе. 
Стали улицы узкими после грохота солнца,

После ветра степей, после дыма станиц...

Только грек мне кивнул, площадная брань 8 переулке,

Безволосая Лияа бежит, Подбирая чулок.

Я борсь твоих губ и во рту твоем язва...

Пролетели те ночи городской и небесной лобви.

Теплый хлеб, чернокуарая аремлет Марыся

Пов жестоким бычьим полушубком моим. 
Все же я люблю холодные жалкие звезды

и свов onyxшyо белур matb,

Неуют и под окнами кучи навоза

и траву и крапиву и чахло растущий салат.

Часто сижу 80 Аворе и смотро на кроличьи игры.

Белая выйдет луна воздух вечерний впивать.

Из дому вытащу я шкуру облезлую тигра,

Лягу и стану траву плечи подъемля сосать.

Аа, в обреченной стране самый я нежный и хилый, Братья мои кирпичи, остров зеленый земли.

Мне все равно, что сегодня две униии хлеба, -

Город свой больше себя, больше спасенья лобль. 


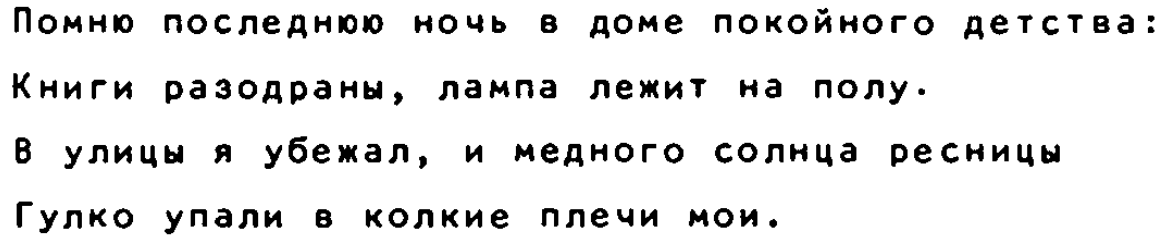

В Польшу налет - и перелет на Восток.

0, как сияет Китайское мертвое солние!

Помно, о нем я мечтал в тихие ночи тоски.

Снова на родине я. Eм чечевичнуо кашу.

Моря Балтийского шум.Тихая поступь ветров.

Ho he откроет мне аверь насуомленная Маша,

Стаи белых лодей лошады грызут при луне.

Mapt 1922 
Сынам Невы не свергнуть ита власти.

И ЧеРнЬ КРНЛатUм ИдОЛОМ ВзоЙАёт.

Аля Инаии Уснувшей, Аля Китая,

Аля черных Стран не верящих - восход.

Bот я сто口 на торжищах Европн,

в руках: озера, города, леса,

И слышу шум и конский топот,

Гортаннше и птичои голоса.

Коль славен наш Господь в Сионе,

Приявший ночь и мглу и муть,

Аля. стран Умерших сотворивший чудо,

ВдохнУвший Солнце УбИенным в ГрУАь. 
Нет, не пюблю закат. Пойдемте дальше, Лида.

8 казарме умирает человек.

Ты помнишь профиль нежный, голос лшсый

из перекошенных остекленелых губ?

А на мосту теперь великолепная прохлада,

Поскрипнвает ветр и дышет Летний сад,

А мне в Дерябинку вернуться надо...

отдернул кисть и выслушал часы. 
Живу отшельником Екатерининский канал 105.

За окнами растет ромашка, клевер Аикий,

Из-за разбитых каменных ворот

я слышу Грузии Азербайджана крики.

Из кукурузы хлеб, прогорклая вода.

Телесный храм разрушили

В степях поет орда,

За красным знаменем стоит она послушна.

Мне делать нечего, пойду и помолось

И кипарисный крестик почелуо.

Cегодня ты смеряишь напропалуо Русь

В Кремле твой Магомет по ступеням восходит.

И на кремле восходит Магомет Ульян

"иль, иль, али, иль, иль Али-Рахман"

И стровтся полки И снова вскачь

ЗОвУт КИтай ПОАнять ЛихОЙ КУМач.

Мне ничето не надо - молод я

И ГОра Своей АушО人 неспокойной,

И вот смотро закат, В Котором жизнь моя

Империи Великой и просторной. 
Усталость в теле бродит плоскостями

На каждой плоскости упавшая звезда.

Мой вырождающийся Аруг двухпалый Митя,

Hас не омоет новнй Иорадн.

И вспомнил Назарет и смуглого Исуса.

Кусок зари у Иудейских гор

И пальцы круглые тяжелые как бусы

И твой обвернутый вкруг подбородка взор.

Mon cлerka notpeckиварт ноги,

Звенят глаза браслетами в ночи,

$И$ весь ияу здоровый И убогий

Где ломанные млеот кирпичи.

Погладил камень и сказал спокойно:

Спи, брат, не млей, к тщете не вожделей.

Творить себе кумир из человека недостойно,

Расти травой тысячелетних дней. 
Мой бог гнилой, но оность сохранил.

И мне страшней всего упругий бост и плечи,

и женское бедро, и кожи женской всхлип,

впитавший в муках муку страстной ночи.

4 вот теперь броку, как ориген,

Смотрю закат холодный и просторный.

Не Аля меня, Мария, женский плач

И твой вопрос, встахщий в зшби черной... 
И все ж я не живой под кущей Аполлона,

ГАе лавры тернием вошли в Авадцатилетний лоб

ПОА бУРИ ГУЛ, ПОА ЧУАнЫЙ ГОВОР СаАа

Прикован я лирической скале.

Шумит ли Горизонт иль ветр цветной приносит

К ногам моим осколки кораблей,

Линяет кенарь, золотая осень,

Седой старик прикован ко скале. 
И голый я стор среАи снегов,

в пустых ветвях не бродит сок зеленый,

А там лежит исполненный тревог

Мой ГОрОА мерный, звонкий и влюбленный.

И также ходит Mуза по ночам -

Старуха в капоре с своей глухою лирой,

И млерт оноши до пустоты плеча

o девушке нагой тугой и милой. 


\section{СТИХОТВОРЕНИЯ}

$1920-1930$ 
Под рожьо спит спокойно лампа Аладина.

Пусть спит в земле спокойно старый мир.

Прошла неумолимая $c$ косор Алинной.

Сейчас наверно около восьми.

Костер горит. Узлы я греб пальчев.

Сезам.Пусти обратно в старый мир,

Немного побродить в его высоком зале

и пересыпать вновь его лари.

Осины лист АРожит в лазури

И Соломонов Храм поя морем синим спит.

Бредет осел корнями гор понурый

Изба на курьих ножках жалобно скрипит.

В руке моей осколок римской башни,

в кармане горсть песка монастырей.

И ветер рядом ласково покашливает,

И входим мы в отвореннуо дверь. 


\footnotetext{
Плывут в тарелке оттоманские фелюги

И no yглам лари стоят.

И девушка ная Баха фугой

Кивет сто пет тому назан.

0, этот АОМ и я любил KоTAа-то

и знал ее и руки целовал,

Смотрел сентиментальные закаты

и моря синето nолуовал.
} 
0, заверни в конфетную бумажку

Храм Соломона с светом желтых свеч.

Пусть ест его чиновник важно

И девушка с возлобленным в траве.

Крылами сердче ударяет в клетке,

Спокойней, милое, довольно ныть,

Смотри, вот мальчик бродит с сеткой,

смотри, вот девушка наполнена весны. 
Сияит она, торгуя на дороге,

Пройдет плевок, раскачивая котелком,

я закуро махру, потряхивая ноги,

Глаза вздымая золотой волной.

И к странной девушке прижму свои ресничн,

И безобразнуо всо молодость свор,

И нас покроет синий звездный иней,

И стану девушкой, торгующей средь вьюr. 
Gery a Hочи над Финско⿴ дорогой.

России не бшло - колониальный бред,

А там внутри земля бурлит и воет,

ВСтает мохнатнй И звериный человек.

Мы чуждых стран чужое наслоенье,

Мы Запада владыки и князья.

Зачем родились мы в стране звериной крови,

Где у люаей в глазах огромная заря.

Я не любло заро.Предпочитар сөист и буро,

Осенний сөИст И безнадежный сөист.

Пусть ВиФлеем стучит И воет: "Жизни новой!"

я волнами язшческими полн.

Косшм углом Приподнатше плечи,

Ha черепе потухшеe личо:

Плывет Орфей - прообраз мой далекий

Среди долин, что тарт на заре.

Даны мне гулким медным Аполлоном

Мелезнше и воля и глаза.

И вот я волком рыщу в иистом поле,

h вот овчой бреду no ropopam.

В сухой дремоте оптинская пустынь.

Нектарий входит в монастшрский саА.

Рябое солнце. Воздух вишней пахнет.

Художники Распятому каяят.

Бола Россия - черкөи и погосты,

Касдатные сухие терема.

и человек умолк, и берег Финский хлещет,

Губернская качается луна. 


\section{ИСКУССТВО}

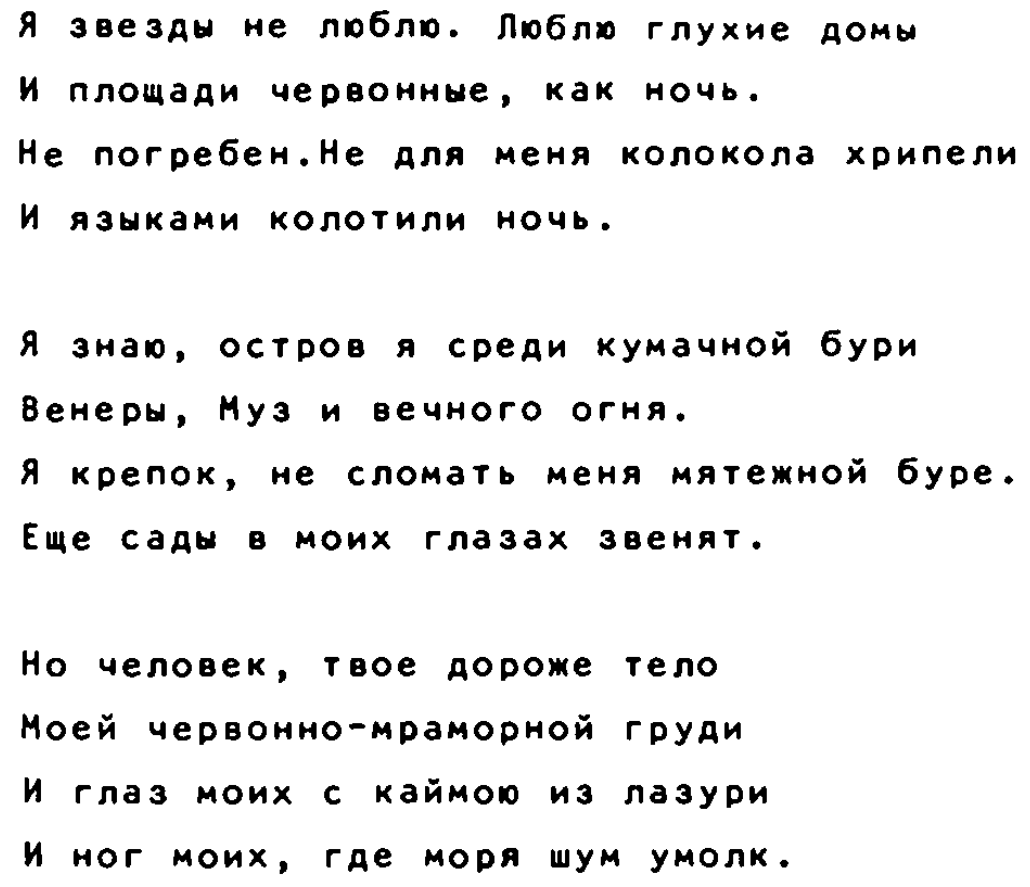


я снял сапог и променял на звезды,

А звезды променял на ситцевый халат,

Как глуп и прост и беден путь Господний,

я променял на перец шоколад.

Мой аруг ушел и спит с осколком лиры,

Он все еще Эллады ловит вздох

И чудится ему, что у истоков милых

Склоняя лавр, возлобленная ждет. 
Я променял весь Аивный гул природы

На звук трехмерный, бережный, простой.

Но помнит Он Аалекие народы

И треск травы И волн далекий бой.

Лобло слова: предчувствур Паденье,

Забвенье смысла их средь торжищ городских.

Так звуки У и А приемлот шум трамвая

И завыванье проволок тугих.

И Ты, Потомок мой, Под стук сухой вокзала,

ПОА веткой рельс, ТЫ вспомнишь обо мне.

В последний раз звук А напомнит шум аубравы,

В послеаний раз звук Е напомнит треск травы.

nonb 1922 
Немного меда, периа и вервены

И темный вкус от рук твоих во рту.

Свиваття поднявшиеся стены.

Над нами европейчы ходят и поОт

Но вот они среди долин урала,

они лежат в чепях и слышат треск домов

Средь плочадей, средь улич одичалых,

Средь опрокинутых арийских беретов. 
Лишь шумят в непогоду ставни,

Сквозь сквозные Аома завыванье полей.

Наш камин, и твое золотое лицо, словно льдина.

3а окном треск снетов и трава.

Это вечер, Мария.Средь развалин России

Горек вкус у вина.расскажи мне опять про любовь,

Про крылатую, черную птицу с большими зрачками

И с костями, как красная кровь. 
Ночь отторела оплшвшей свечой восковой

И ная домом моим белое солнце скользит,

Hа паркетном полу распростерлись иглы и хвоn,

Aполлон по ступенькам закутавшись в шубу бежит.

Но сандалии сохнут на ярко начищенной меди.

Знаю, завтра придет, и на лире уныло бренча,

Будет петь о снетах, где так жалобны звонкие плачи,

Будет кутать усталые плечи в меха. 


\section{Анне Радловой}

Вч римскор Аержавной колесничей

Несетесь вскачь. Над Вами день клубится,

А ПоА ногами зимняя заря.

И страшно Под зрачками римской знати

Найти хлшстовский Аух, московскуо тоску

Царицн корабля.

Но помните Вы Аушный Геркуланум,

Везувия гуяение и взлет,

и ночь, и пепел.

Кружево кружений.Россия - Рим.

20 aвгуста 1922 


\section{( Нз альбома Б. Смиренского)}

Осыплют липы пьедестал чугунный

И дети в ночь уйаут пересыпать песок.

1921

(Нз алобома Л.Борисова)

Hе лунному, но звонкому поэту

Любительо смапагаa и панели

И солнием окропленных пустырей.

4 марта 1923 
Mы ЗапаAа nослеAние осколки

в стране тесовых изб и азиатских вьог.

Удел Овидия влачим мы в нашем доме...

- Да буаь смелей, я подаержу, старик.

И бросил старика.Канал Обводннй.

Тиха луна, тиха вода над ним.

Самоубийча я.Но ветер легким шелком

До щек Аотронулся и отошел звеня.

18 марта 1923 
Мы рожаены аля Пишности аля славы.

Аля нас судьба угасших родников.

0, соловей, сверли о жизни снежной

и шелк пролей и вспыхивай во мгле.

мы соловьями стали поневоле.

Koraа нет жизни, петь нам суждено

0 rородаx norибших, о надежде

И о любви кипящей как вино.

4 ноября 1923 
Не пестрою, но радостной природой

И башнями колоколов не соблазнен,

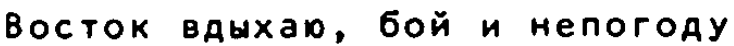

ПОА мякотьо шарманочныХ икон.

Шумит Москва, широк прогорклый говор,-

НО Помно я александрийский 3 вон

Огромных площадей и ангелов янтарных

и петербургских синих пустырей.

Тиха луна над голою поляной.

Стой человек в шлафроке! Не Ашши!

И снова Бой румяный и бахвальный

Нар насурмленным бархатом реки.

1923 
Ао белых барханов твоих

От струй отАаленного моря

Небхвшей отчизны моей

Летарт чугунные звуки.

Tвои слюдянше глаза

И тело из красного воска...

в прозрачных руках города,

B Horax - Kaвказские горы.

у гулких гранитов Невы

У домов своих ОАичалых

В колоннах Балтийской страны

\#ивет Петербургское племя.

Стучит на рассвете трава,

Купиы кричат на рассвете.

Раскосо славянской Руси

сбирается прежнее вече.

И страшен у белых колонн

ПОА небОМ ОСенним И синим

язык расписной, как петух

На Аревне-язической хате. 
Григорих llмерелосону

Но знар я, корабль спокоен,

ЧТО ОН Недвижим СРЕАЬ ПУЧИнЫ,

पто не вернуться мне на берет,

Что только тень моя на нем.

Oна блуждает ночь⿱ темной,

Она влюбляется и пляшет...

5 mapta 1924 
पас от часу редеет мрак медвяный

И зеленепт за окном листы.

я чувствуо - желаньем полон мрамор

вновь низвести небесные черты.

В несозданном несотворенном мире,

гае все полно анханием твоим,

Hе назову гробницами пустнни

Я образы тревожные твои.

Охваченный твоим самосожженьем,

Не жау, что завтра просветлеешь ты

И все еще ловлю в дыму твое виденье

И уходящий голос Твой люблю.

И аля меня прекрасна ты,

И мать И АОчь одновременно

Средь клочьев аыма и огня.

Ha ложах точно сна виденья

Сияим недвижны и белы,

И самовольное встает

Полулетящее вияенье,

Неотразимое явленье. 
IреA разнOLветно⿴ толกON

Летящих nap no вечерам,

Под брызги рук ночных таперов

Hас было четверо:

Спирит с тяжелым трупом души своей,

Белогвардейский капитан

C неудержимой $к$ родине лобовьо,

Тяжелоглазый non,

Молящийся над кровьо,

Я, сосуд пустой

С растекшейся во вся и все душою.

Аалекий свет чуть горы освещал

И вывески белели на килищах,

Korá из дома вышли трое в ряа

И побрели no nenелищу.

я вышел тоже и побрел куда

Глаза глядят С невшносимой жаждой

Услышать моря плеск и парусника скрип

И торопливое деревьев колыханье.

คHВар口 1925 
Oн аумал: вот следн

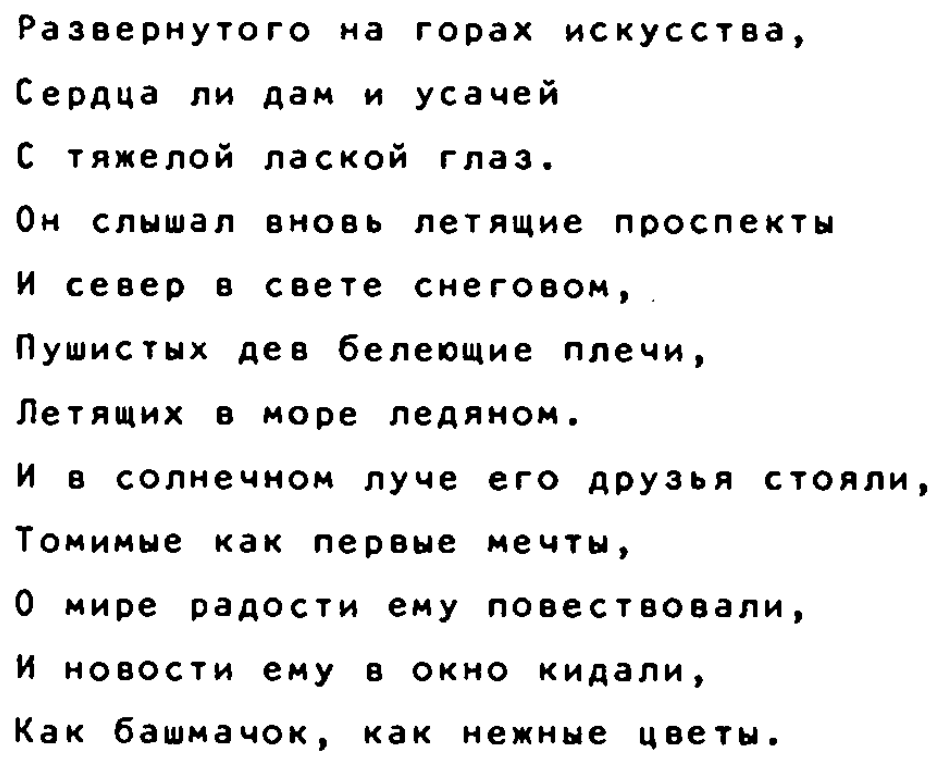

0 мире радости ему повествовали,

и новости ему в окно кидали,

Как башмачок, как нежные цветы. 
Я стал просвечиварщей Формой,

Свисающейся ветвью винограда,

Но нету птиц, клюющих рано утром

Mои качающиеся плоды.

Я вижу Алительные дороги,

Подпрыгивавщие тропинки,

Разнохарактерные толпы

Разносияющих людей,

И выплывает в ночь Тептелкин,

в моем пространстве безызмерном

Oн держит Феникса сиянье

в чуть облысевшей голове.

А на Москве-реке далекой

Стоит рассейский Кремль высокий,

В нем голубь спит

В воротничке,

Я сам сижу

Ha o6лучке,

Mon snepeaи - за mноD rpo6,

в нем тот же я - совсем аругой,

Со мной подруга, Аикий сая -

Луна ная желтизной оград. 
Bесь мир пошел дрожащими кругами

И в нем горел зеленоватый свет.

Скалу, корабль и девушку над морем

Увидел Я, Из АОму выходя.

По Пряжке медленно за парой пара ходит

И рожи липкие. И липкие чветы.

С моей души ресниц своих не сводат

высокие глаза твоей Ауши. 


\section{ЛЕНИНГРАAСКАЯ НОЧЬ}

8 разноцветящем полумраке,

В венке из черных лебедей

Он все равно 6 развеял знаки

Минутной рОАИна Своей.

И говорил: "Усыновлен я,

Bсе время ощущах связь

С звезАой Сияющей внсоко

И может быть в последний раз.

Но нет, но нет, слова солгали,

ведь умерла она давно.

Но как лобовник не внимар

И жау - восстанет предо мной.

Aруг, отойаи еще мгновенье...

Аай мне взглянуть на лоб златой,

На тонко вспененные плечи,

На Подбородок крУжевной.

Пусть, пусть Психея не взлетает -

8 все же чувствур еe

И вижу, вижу - вылезает

И предлагает помело.

И мы летим над бывшим градом,

НаA лебединор Невой,

Над поредевшим Летним садом,

Над Фабрикой с большой трубой.

Все ближе $к$ солнечным покоям:

И плеч костлявых завитки,

Хребет синерщий и крылья

И хилый зая, как мотыльки.

Bнизу все спит в ночи стоокой -

Аом Отдыха, Аворец Труда,

Меж томно-синими домами

Бежит ФИлОСОФ, ТОчно Хлыст, 
В пальто немодном, в летней шляпе

И, ножкой топнув, Говорит:

"Bсе нерти мы в открытом мире

Иль превращаемся в чертей.

Мне ХОЛОАно, Я ПЬян СеГОАня,

Я может бЫть Последний лист".

тептелкин, встав на лапки, внемлет

И ну чирикать из окна:

"бессмыслича ваш яикий хохот,

Спокоен я И снова сыт".

И преа окном змеей гремучей

Опять вознесся Филострат

И, сев на хвостик изумруаный,

Простором начал искушать".

Летят надзвездные туманы,

С Психеей тонкор несусь

3а облака, под облаками

Меж звездами и за пуной. 
Война И ГОЛОА тОчно СОH

Оставили лишь скверный привкус.

Мы пронесли высокий звон,

Веаь зто был лишь слабый искус.

И милые его Арузья

Глядят на рта его Авиженья,

На Аряблых впадин синеву,

Ha rлaz ero оцепененье.

По улицам народ ияет,

Apyroe бьется поколенье,

Ему смешон наш ГОрАшй ХОА

И наших ауш серацебиенье. 
Нам в оности Флорениия сияла,

Нам Филострата нежного на улицах являла -

Не Фильтрами мы вызвали его,

Не за околицей, гае сором поросло.

Поэзией, как утро, сладкогласной

$O_{\text {н }}$ вызван был на улице неясной. 
Тарт मома. Любовь ияет, Хохочет

Из сада спелого эпикурейской ночи.

Ей Снился Юный Сая,

Стрекочущий, поющий,

веселше, как дети, голоса

И битвы шум, неясный и зовущий.

Как тяжела любовь в шестнадцать пет.

Ей кажется: norac прелестный свет,

И всоду лес встает ужасный и Аремучий,

И вечно будет АожАЬ, И вечно будут тучи. 
В тиши ночной

Я жду тебя,

Тоскуя и любя,

Ты ангел чистый ПреАО Мной,

Лю6лю одну тебя.

Огнями полон гулкий зал,

Boкpyr aухи, иветы,

Tе6я в толnе я отыскал,

оркестр галоп играл.

Ho вот apyromy отдана

Твоя рука,

И злая жает меня суаьба

Hочного игрока.

В Монако мизнь окончу $а$,

Где море так шумит,

И не узнаешь никогда,

где оный труп зарыт. 


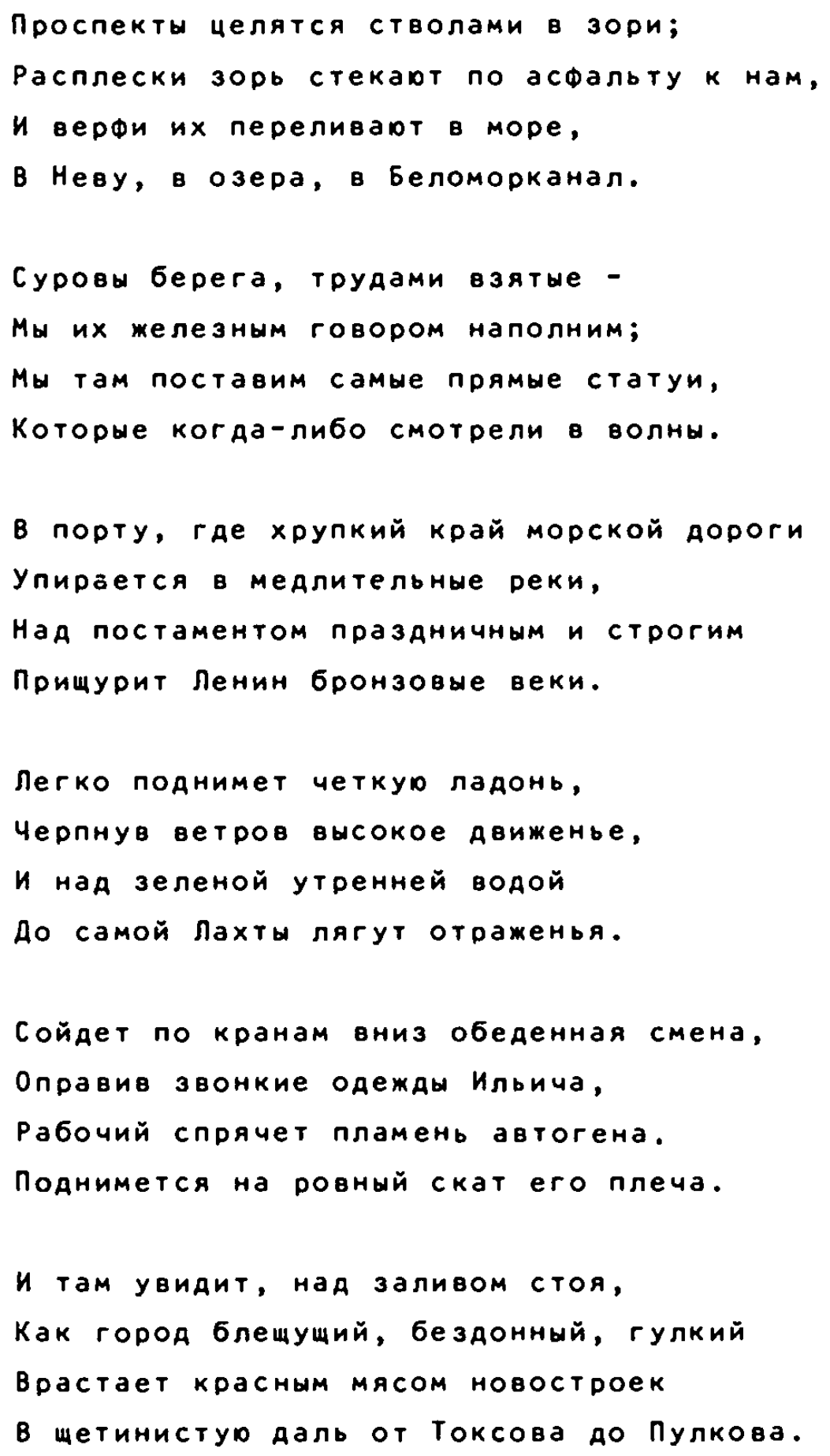


TЫСЯЧА АЕВЯТЬСОT ДВАДUАTЬ

กЯТแตั ГОA 


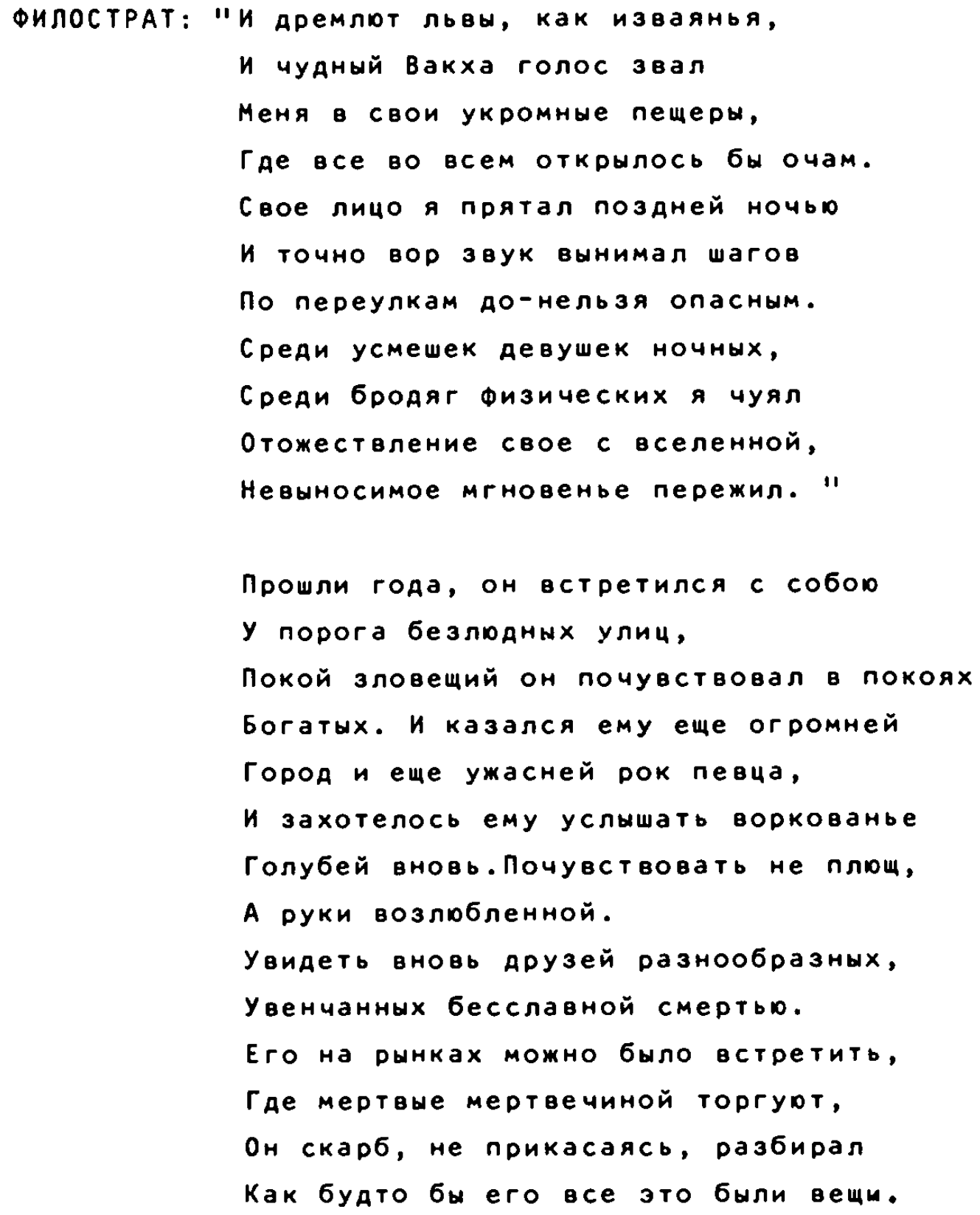

Тептелкин на бумагу несет "Бесов", обходит шажком фигуру, созериариуо бесконечность.

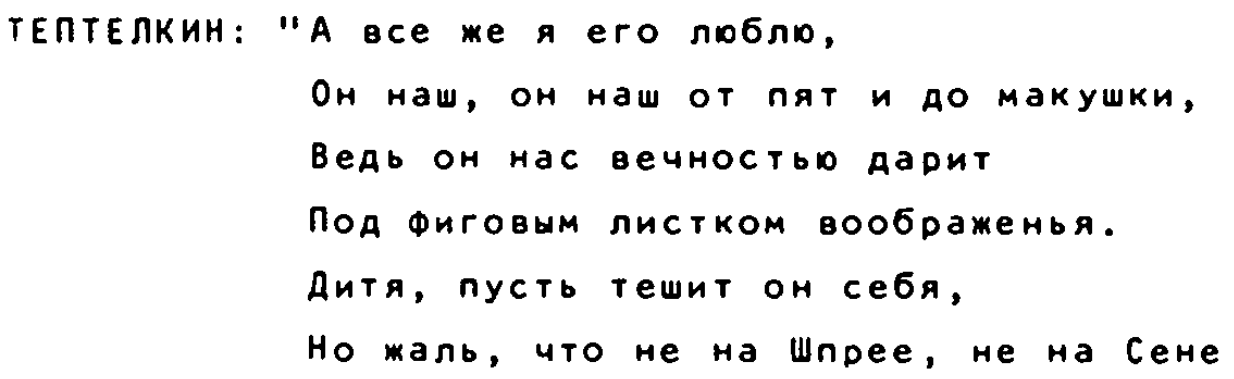


Сейчас. Torá воспользоваться им всеиело

Mогли бы мы. И бреа его о Фениксе

Мы заменили 6 явьо."

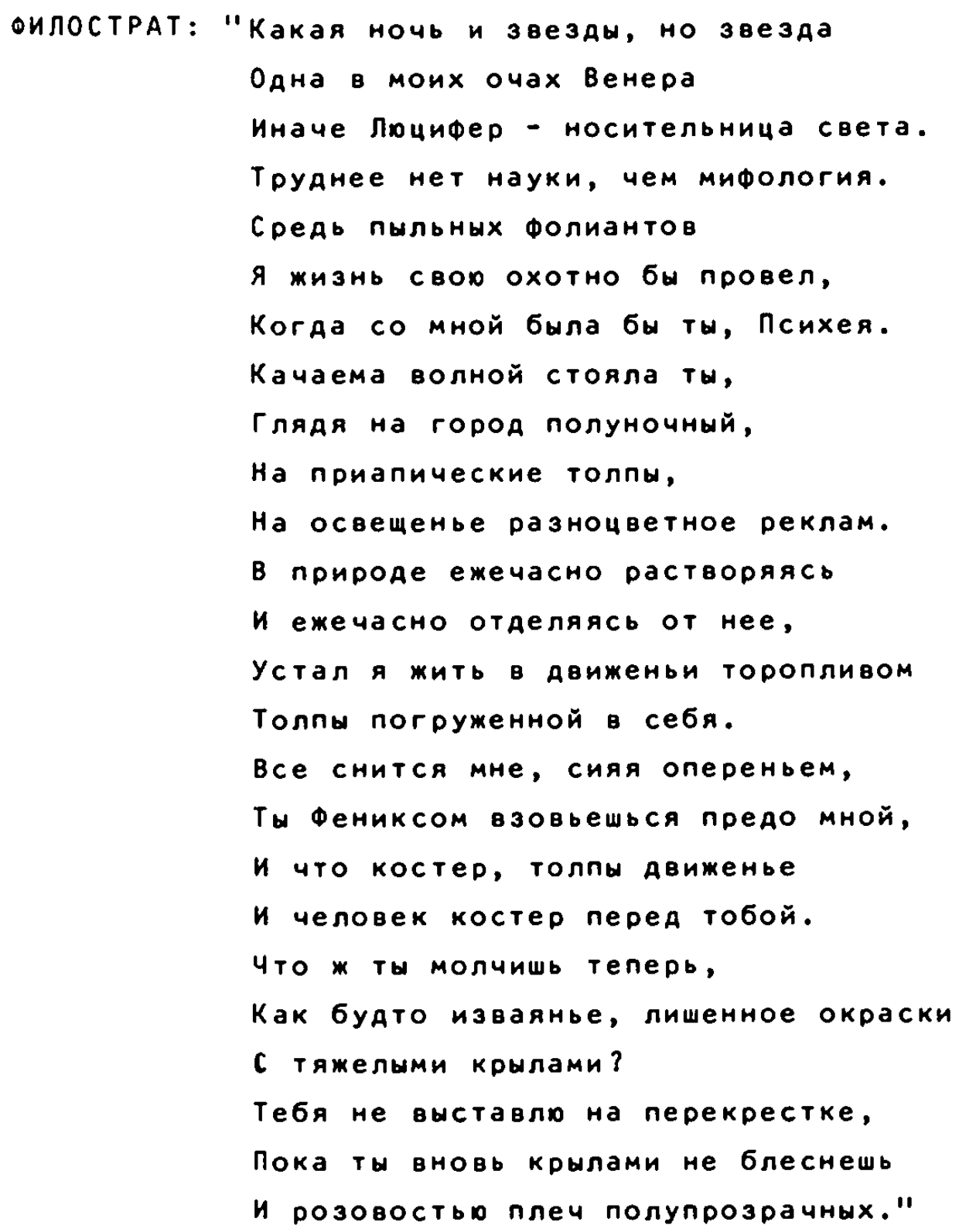


я забежал в своей крылатке мокрой

3а Клавдианом в серых переплетах."

КНИЖнИК: "ВЫ КажАЫЙ АЕнь ЗахОАИте.

В крылатке, насколько помні,

He забегали вы. A книги

в мышиных переплетах все проданы.

Вот "Ночи" Dнга, реакий экземпляр

С Франиузского на итальянский,

Он вам необходим для постиженья душ.

Ero аля вас я выбрал в куче хлама."

(Филострат yбeraet)

Свист 6ури. Шестой этаж, черный ход, перед дверьо помойное ведро. Стены увешаны потертыми и продранными коврами. กрurant 6 noxn.

LUГAHKA: "TaK в Gora Bu me Bepyete?"

ФИЛOCTPAT: "Hет."

Улича. Lыганка с Тептелкиным ияет под ручку. Тептелкин несет подмышкой гитару в Футляре.

ЦЫГАНКА: "СКажите, Он опасный человек?"

ТЕПТЕЛКИн: "Безумеч жалкий."

Тептелкин И иыганка входят в подъезд яркоОсвещенното gома. Бал-маскарад. Тептелкин под руку с Филостратом.

ТЕПтелКИН: "Поете вы,

Как должно петь темно и непонятно.

Mrpon cлов пусть назовут rлyпuы

ваш стих.вы притворяетесь 


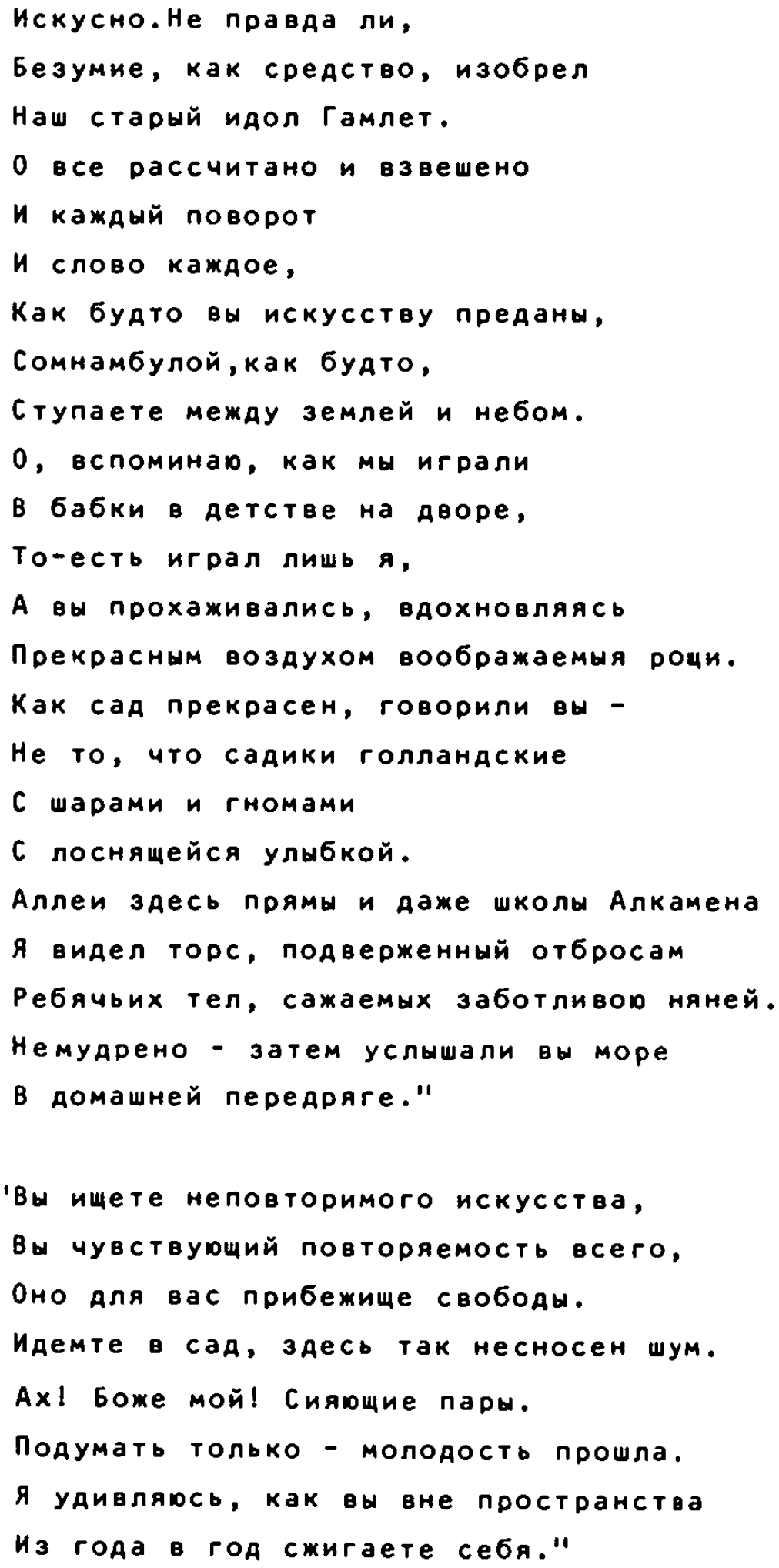

Комната Филострата. Филострат лежит. Читает: 


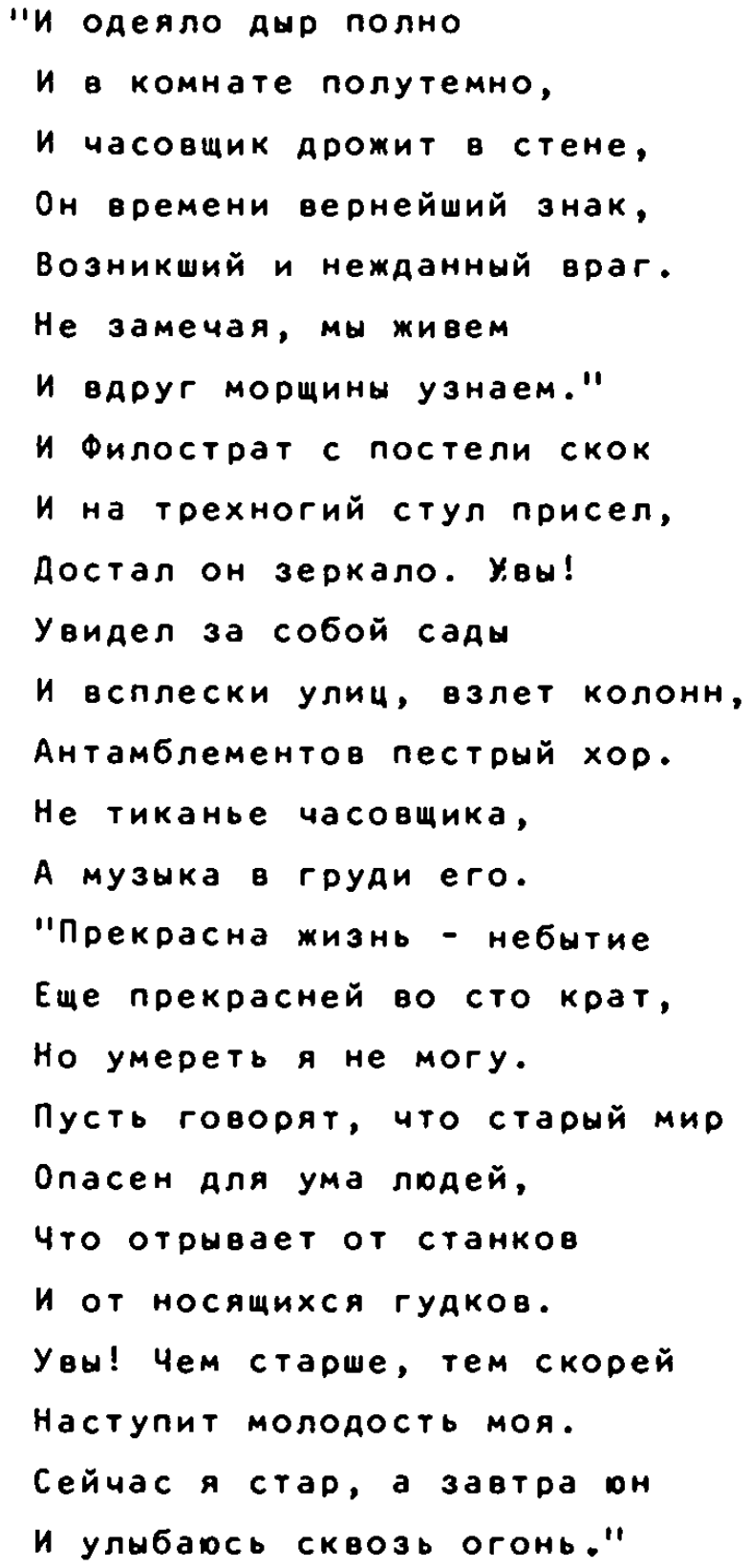

$$
\text { Bep6a }
$$

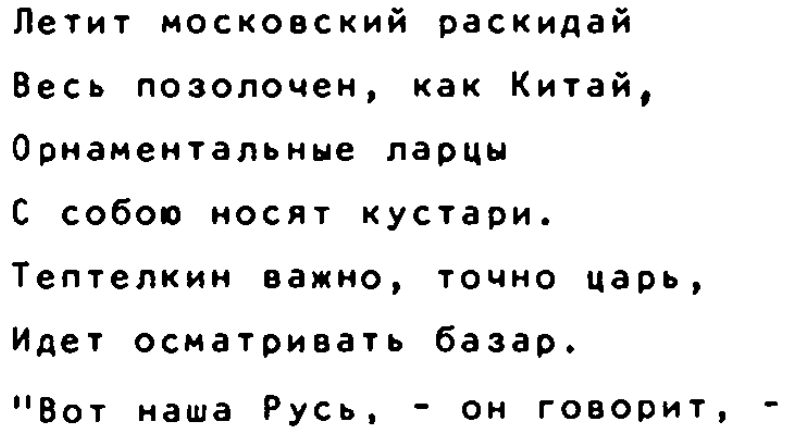


Заморских штучек не лю6лю.

Cоветы - это наша Pусь,

они хранились в глубине

ПОА византийскою парчой,

ПОА западно10 yenyxой."

Филострат идет с рукописьв в театр.

Первый акт. Темно.

ФИЛОСТРАТ: "Страшнее жить нам с каждым Годом, Мы правим пир среди чумы

Погружены в свои печали.

Сады для нас благоуха⿴囗,

Мы слышим моря Аальний гул,

И мифологией случайной

Мы вызываем страшный мир

В толnу $и$ в город малолодный,

Где мертвые тела лежат,

Стоит прекрасна и бела

Венеры статуя и символ.

Саяитесь, Сильвия,

Составил я стихотворение аля вас:

"Стонали, точно жены, струны -

Ты в черных нас не обращай

И голубями в светлом мире

дожить до растворенья дай.

Чтоб С ГорАОстьо неколебимой

Высокие черты несли,

Как излияние природы,

Ушедшей в бесполезный цвет,

Сейчас аля нищих бесполезный." 
Сильвия: "мне с вами страшно,

Зачем бередить наши раны.

Еще не утеряли свет

Земля и солнце и свобода.

Возьмемте книгу и пойдем

Читать ее под шелесты Фонтанов,

Пока охваченные сном

Друзья покоятся.

3абудем ГОрОА.

Есть в статуях вина очарованье

Высокой осени пьянящие плоды,

Они особенно румяны,

Но аля толпы бесцветны и бледны

И как бы порожденье злобной силы

Они опять стихией стали тьмы."

В коние аллеи появлется старик Философ:

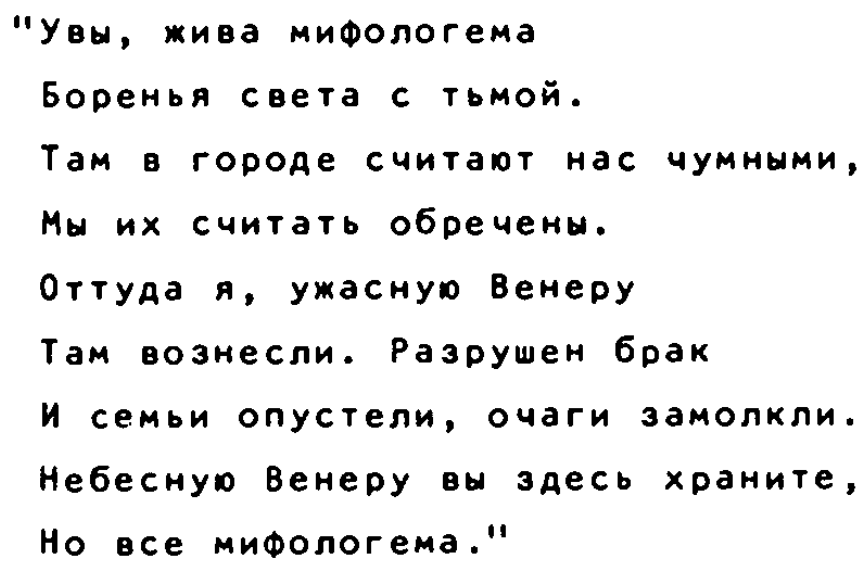

"Ушел старик, борсы, он занесет заразу в наш замок.

C некоторых пор веселье как-то иссякает наше,

все реже слышны скрипки по ночам,

Bсе реже опьянение нисхояит.

И инотда мне кажется, что мы

Окружены стеной недобровольно." 
Bо Аворе появляетя человек:

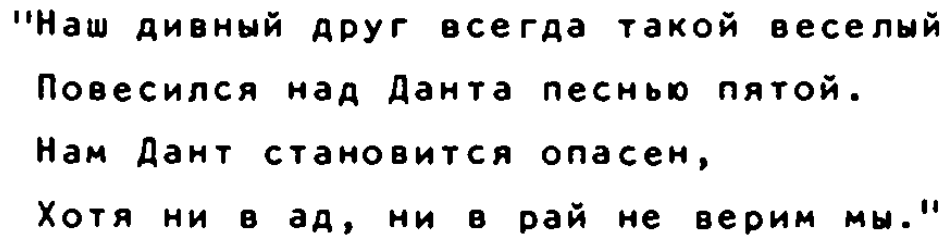

Песня Сильвии:

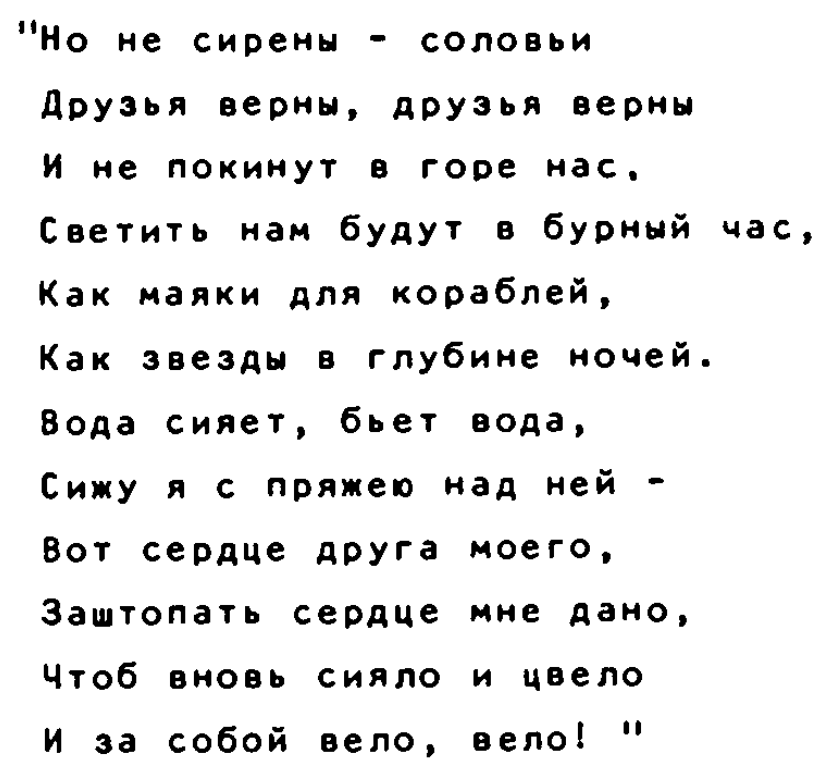




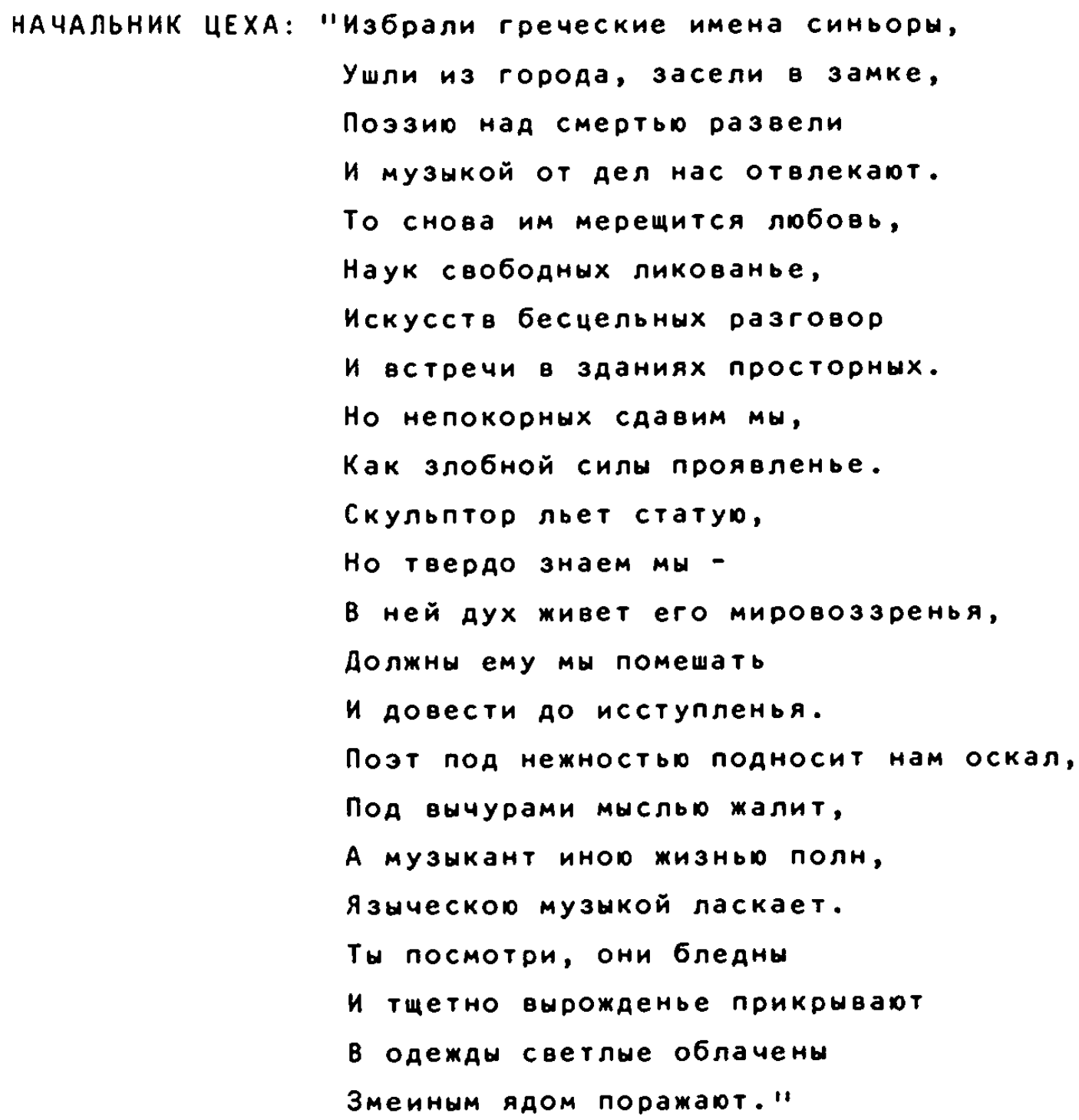

КПитер: "Mеркурий, Что видишь ты?"

MЕРКуриИ: "Я вижу девушку в листве струистой, Она готовится купаться в вихре света И с ней стоит толпа несиастных гномов."

BEHEPA: "Tы зол на них, Меркурий, Xorb век твой наступил, B moем пребуаут веке."

NIИTEP: "Hеподчинение судьбе карается жестоко." 
BAKX: "я подкрепль их силой опьяненья."

AПолЛОН: "Искусства им аадут забвенье."

BEHEPA: "ЛюбовнИкамИ ИСтИнМЫMИ бУАУт."

Статуи прохаживаотся. ОАни ИАут горАО И...*

Aругие печально. Bенеру ведут под руки Вакх и Aполлон,

она ияет пошатываясы и опустив голову. На лужайке музы

исполняют простонародные песни и пляски. В зале шум.

тептелкин вскакивает:

"нам опять показали кукиш в кармане."

И10HB 1925

* nponyck в pyкоnисном cпucke. 
ОПЫТЫ СОЕАИНЕНИЯ СЛОВ

NOCPEACTBOM PUTMA 


\section{ПОЭМА КВАAРАTOB}

1

Aa, я nozt tparnueckoй забавы,

А все же жизнь смертельно хороша.

Как буато женщина с линейными руками,

А не тлетворный куб из меди и стекла.

Снует базар, любимый rовор черни.

Фонтан Бахиисарайский помнишь, Аруг?

так от пластических венер в квадраты кубов

Провалимся.

Hа скоротечний путь вступах неизменно,

Лerкa hora, mo ynaAaer nyтb:

На Киликийский Тавр - под ухом гул гитары,

А в ресторан - но рядом аушный Тмол.

Aа, человек подобен океану,

A most ero nonoбен янтарі,

что на брегах лежит, а хочет влиться в пламень

Orромных рук, взметариих заро.

И голосом своим нерукотворным

Даруя Аань Грядущим племенам,

Я знар - кирпичом огнеупорным

Лежу у христианских стран.

Струна гудит, и Аншат лавр и мята

Костями зллинов на ветряной земле,

И вот лечу, подхваченный спиральо.

rae ynaAy?

И вижу я несбывшееся детство,

Сестрн не дали мне, ее не сотворить

ни рокоту аубрав великолепной славы, 
Hи золоту инraнckoro watpa.

Aa, тело - океан, a moзr haA головов

Склонен в зрачки и вияит листный СаА

И времена тугие и блатие

Великой Гречии.

4

Скрутилась ночь. Аиша, стан девичий,

Смотри, на лодке, Пряжку серебря,

Пливет заря.НО легкий стан девичий

Ответствует: "Зари не вижу в."

5

Aа, я позт трагической забавы,

А все же жизнь смертельно хороша,

Как буато женщина с линейными руками,

А не тлетворный куб из меаи и стекла.

Снует базар, лобимый говор черни.

Фонтан Бахиисарайский помнишь, Аруг?

Так от пластических Венер в квадраты кубов

провалимся.

Покатнй дом и гул протяжншх улиц.

Отшельника квадратный лоб Горит.

Овальнам озером, бездомнам кругом

По женским Плоскостям скоЛЬзит.

Да, ты, позт, владеешь плоскостями,

Квадратами ямбических фигур.

Морей погасших не запомнит память,

Hи белизнш, ни золота Харит.

HOHD 1922 


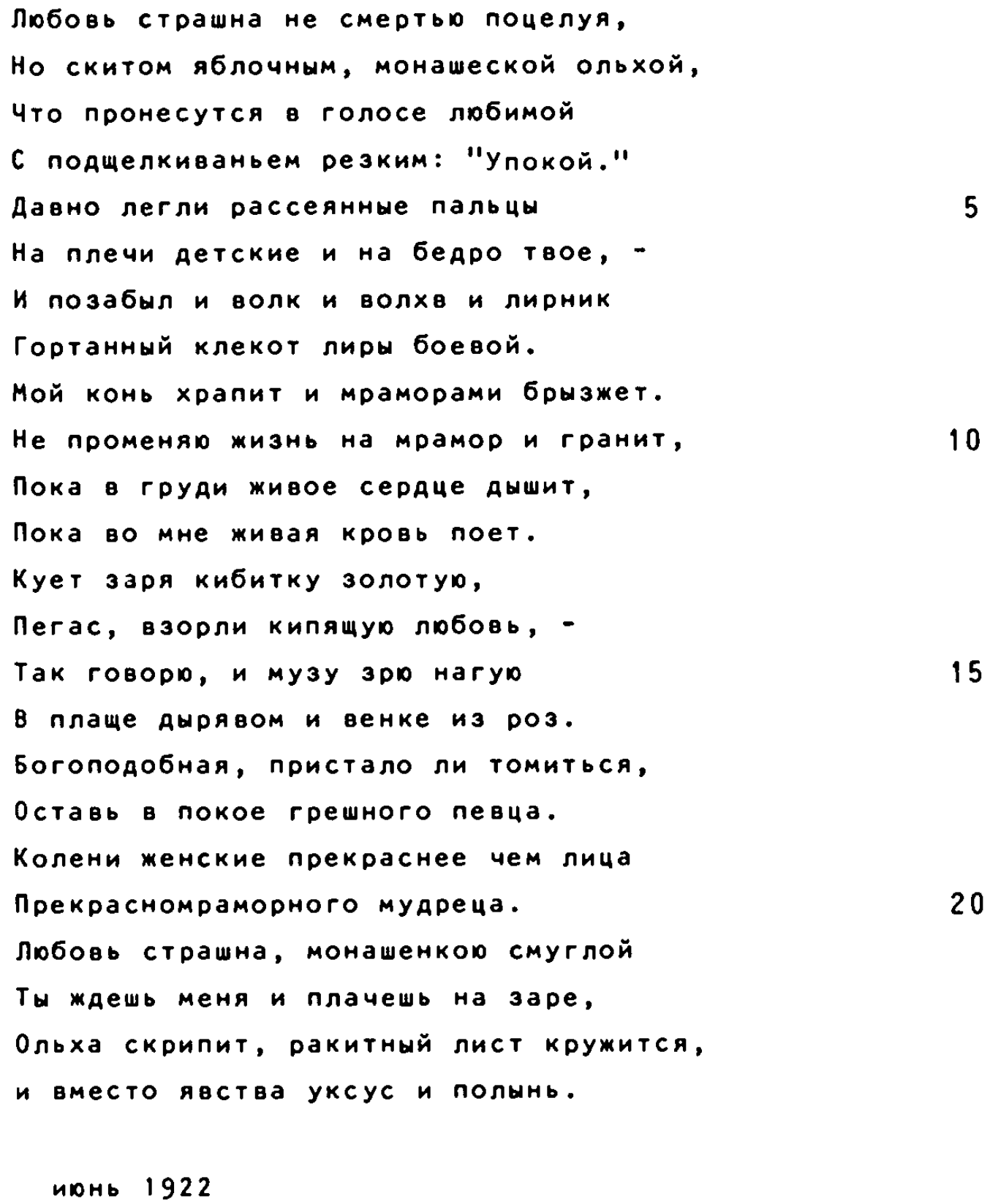


Yеловек

Среяи ночных блистательных блужданий,

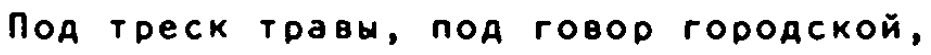
Я потерял морей небесных пламень,

я потерял лирическуо кровь.

Кога заря свои подвемлет перья,

Я у ворот безлиственно стор,

Мой лучезарный лик в чужие плечи канул,

В крови случайных менщин изошел.

Xop

Вновь повернет заря.В своей скалистой ночи

0рфей раздумьо предан и судьбе,

И звуки ластятся, охватываот плечи

И лире тянутся, но не нахояят струн.

Человек

Не медномраморным, но малким человеком

Стор на мраморной просторной вшшине.

А ветр шумит, непойманные звуки

06ратно падарт на золотуо ночь.

Мой милый аруг, сладка твоя постель и плечи.

Что мне восторгов райские пути?

Hо ПОмно я весь Холод зимней ночи

И храм большой ная синей крутизной.

Xop

Обыкновенный час Аарован человеку.

Так отрекаемся, енва пропел петух,

от мрамора, от золота, от хвои

П входим в мизнь, откУАа выХОА - смерть.

aвгут 1922 
Шумит Родос, не спит Александрия,

И в черноте распушенных зрачков

Встает звезда, и легкий запах море

Горстями кинуло.И снова рыжий день.

Позт, ты Аолжен быть изменчивым, как море,-

Не заковать его в ущелья гулких скал.

Мне вручены цветущий финский берет

И римский воздух северной страны.

ноябрь 1922 
я полюбил широкие каменья,

Tpenory трав на пастбищах крутых, -

То снится мне.Наверно день осенний,

h домдь прольет на улицах благих.

Давно я зряч, не очушаю кршши,

Прозрачен аля меня словесний хоровод.

Я слово выпущу, Аругое кину выше,

Hо все равно, они вернутся в круг.

Но медленно волов блатоуханье,

Ho пастухи о праздности nowr,

у гор авугорбых, смуглогруды лоди,

И солнце виноградарем стоит.

Но ты вернись веселор подругой, -

так о словах мы бредили в ночи.

будь спутником, не богом человеку

Мой медленный раздвоенный язык.

PHBapb 1923 
В селеньях городских, гяе протекала оность,

Гае четвертьо луны не в меру обольщен...

0, море, нежный братец человечий,

Нечеловеческой тоски исполнен я.

Смотро на золото предутренних свечений,

Ванхар порами балтийские ветра.

Невозвратимого не возвращат,

Hапрасно музыка итрает по ночам,

He позабуау смерть и шелестенье знар

И прохожу ная миром одинок.

Февраль 1923 
Крутым быком пересекая стены,

Упал на площадь виноградный стих.

Что аелать нам, какой суровой карой

Ему сиянье славы возвратим?

Mu закуем его в тямелше напевы,

В старинные чугунные слова,

Чтоб он звенел, Чтоб надувались жилы,

Чтоб золотом густым переливалась кровь.

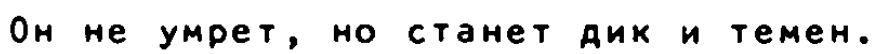

И буаут жить в груаи его слова,

И возвышает голос Он, И голосом Подобен

набегу волн, сбивающих дома.

Февраль 1923 


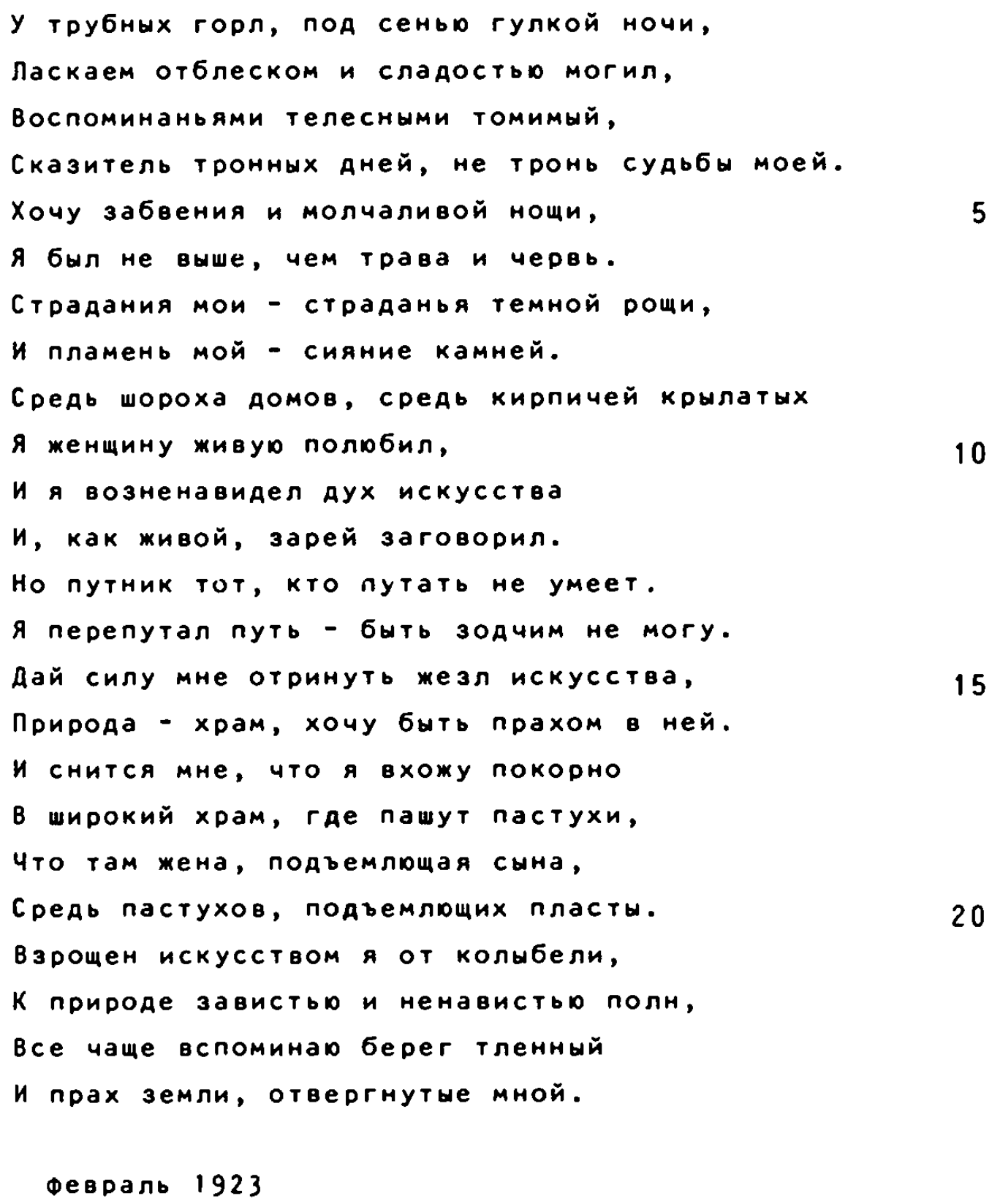


И пестрой жизнь моя была

ПоА небом северным И острым,

Гае мед хранил металла звон,

Где меду медь была подобна.

Мизнь нисходила АО меня,

Как чепь от предков своенравных,

Как сановитый ХОА КОня,

Как смугломраморные лавры.

И вот один средИ болот,

Токинутый потомками своими,

lевец-хранитель город бережет

зрлом слепым над бездыханным сыном.

Февраль 1923 
Не человек: все отошло и ясно,

Что жизнь проста.И снова тишина.

Далекий серп богатых Гималаев,

Среди равнин равнина я

Неотделимая.То соберется комом,

То лесом изойдет, то прошумит травой.

Не человек: ни взмахи волн, ни стоны,

Ни грохот волн и отраженье волн.

И मо утра скрипели скрипки, -

Был ярок пир в потухшей стороне.

Казалось мне, привстал я человеком,

Но ты склонилась облаком ко мне.

Mapr 1923 


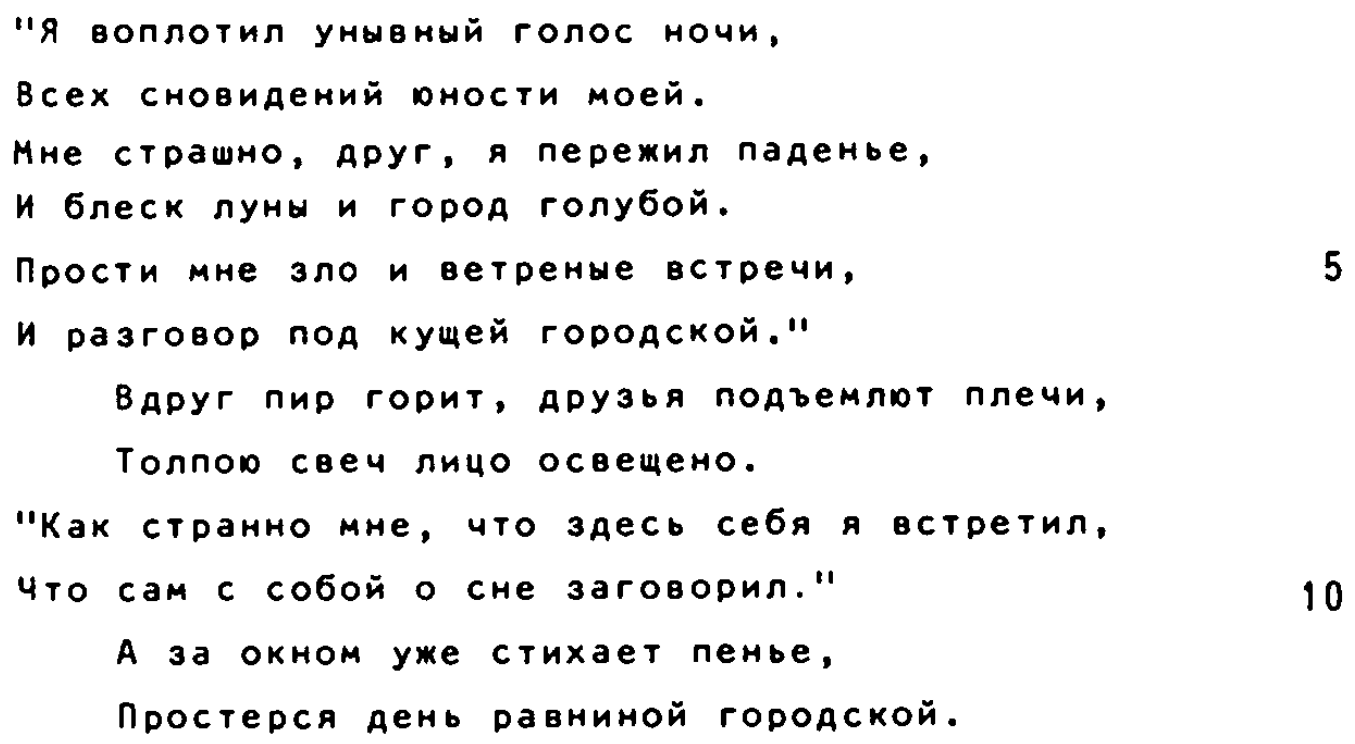

А за окном уже стихает пенье,

Простерся день равниной ГОрОАской.

Xop

"Куда пойдет проснувшийся средо пира,

Толпой Арузей любезных Освещен?"

Но крик Горит:

"Среаь полунощных сборищ

Аыханор рощ напрасно верил $я$.

Cредь очагов, corpetax беглым спором,

СРеАЬ чуманх мне ПрОхоАИт жизнь моя.

Вы скрылись, дни сладчайших разрушений,

Унылый визг стремящейся зимы

Не возвратит на низкие ступени

Спешащих муз холодные ступни.

Кочевник я среяи семейств, спешащих

К безделио. От лавров далеко

Я лиру трогар размеренней и строже,

Шатер любви простерся широко.

Спи, лира, спи.Уже Мария внемлет,

Своей любви не в силах превозмочь,

И до зари вокруг меня не аремлет

Aлександрии башенная ночь."

nоก⿻ 1923 
Оаин средь мглы, среди домов ветвистых

Волнистых струн перебирар прядь.

Так ничего, что плечи зеленеот,

Что язвы вспыхнули на высохших перстах.

Покойных аней прекрасная Селена,

Предстану я потомкам соловьем,

Слегка разложенным, слегка окаменелым,

Полускульптурой дерева и сна.

ноябрь 1923 


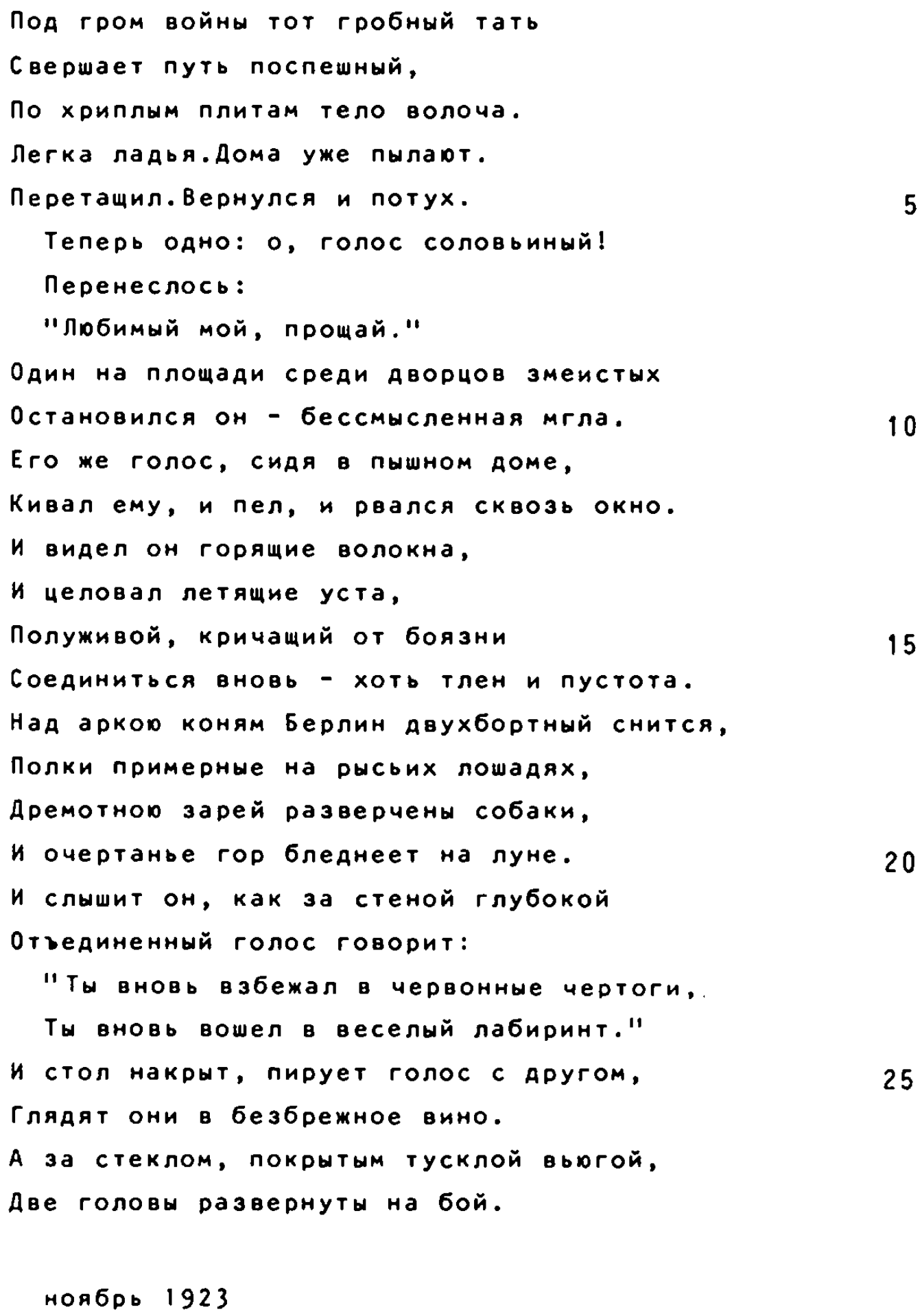

Tеперь одно: о, голос соловьиный!

Перенеслось:

"Любимый мой, прощай." 
Вблизи от войн, в своих сквозных хоромах,

Среяи домов, обвисших на полях,

Развертывая губы, простонала

Возлюбленная Аругу своему:

"Mне жутко, нет ветров веселых,

Нет парков тех, что помнили весну,

0боих нас, блуждавших между кленов,

рассеянно смотревших на зарю.

0, вспомнИ нОчь.СКвозь тУчи воды рвались,

Под темным небом не было земли,

И ты восстал в своем безумьи тесном

В вожаь завыл о буре и любви.

Я разлила в тяжелье стакань

Спокойный вой о войнах и волках,

И до утра пов ветром пировала,

Настраивая струны на уа.

И видел домы ТЫ, Подстриженные купы,

Прощальный голос матери твоей,

Со мной, безбрежный, ты скитался

И тек, и падал, вскакивал, пенясь. "

ноябрь 1923 
И лирник спит в проснувшемся приморье,

Hо тело легкое стремится по струнам

8 росистий Аом, без крыши и без пола,

ГAе C Aругом нежным пность проводил.

U ronoc Bapyr во mpamopax puáet:

"O, apyr мена noбepern.

Своим анханием расчетным

Mое дыханье не лови."

Январь 1924 
Как хорошо под кипарисами любови

На мнимом острове, в Аремотной тишине

Стоять И МАать ПоАрУГИ ПрОбужАенье,

Пока зарей холмы окружены.

Так возросло забвенье. Без тревоги,

Ясней луны, сижу на камне я.

За мной жена, свои простерши косы,

Под кипариса памято повела.

Январь 1924 


\section{ПCИХEЯ}

Спит брачный пир в просторном мертвом граде,

и узкое лицо целует Филострат.

За ней весна свои цветы колышет,

За ним заря, растущая заря.

И Снится Им обоим, Что приплыли

Хоть на плотах сквозь буро и войну,

Hа ложе брачное поА сенио густо口,

В спокойный дом на берегах Невы.

9нварь 1924 
0 , сделай статуей звенящей

Mon oбonouky, Господ,

Чтоб после отверстого плена

Стояла и пела она

О жизни своей ненаглядной,

0 чудной подруге своей,

Под сеньо смарагдовой ночи,

у врат 8авилонской стены.

Аля вставшего в чреве могилы

Спокойная жизнь не страшна,

Он будет, конечно, влюбляться

8 домовье, в мену у огня.

И ложным покаже гся $\mathrm{y} \times 0$,

И скипетронощный прибой,

и золото черного шелка

Лохмотий его городов.

anpent 1924 


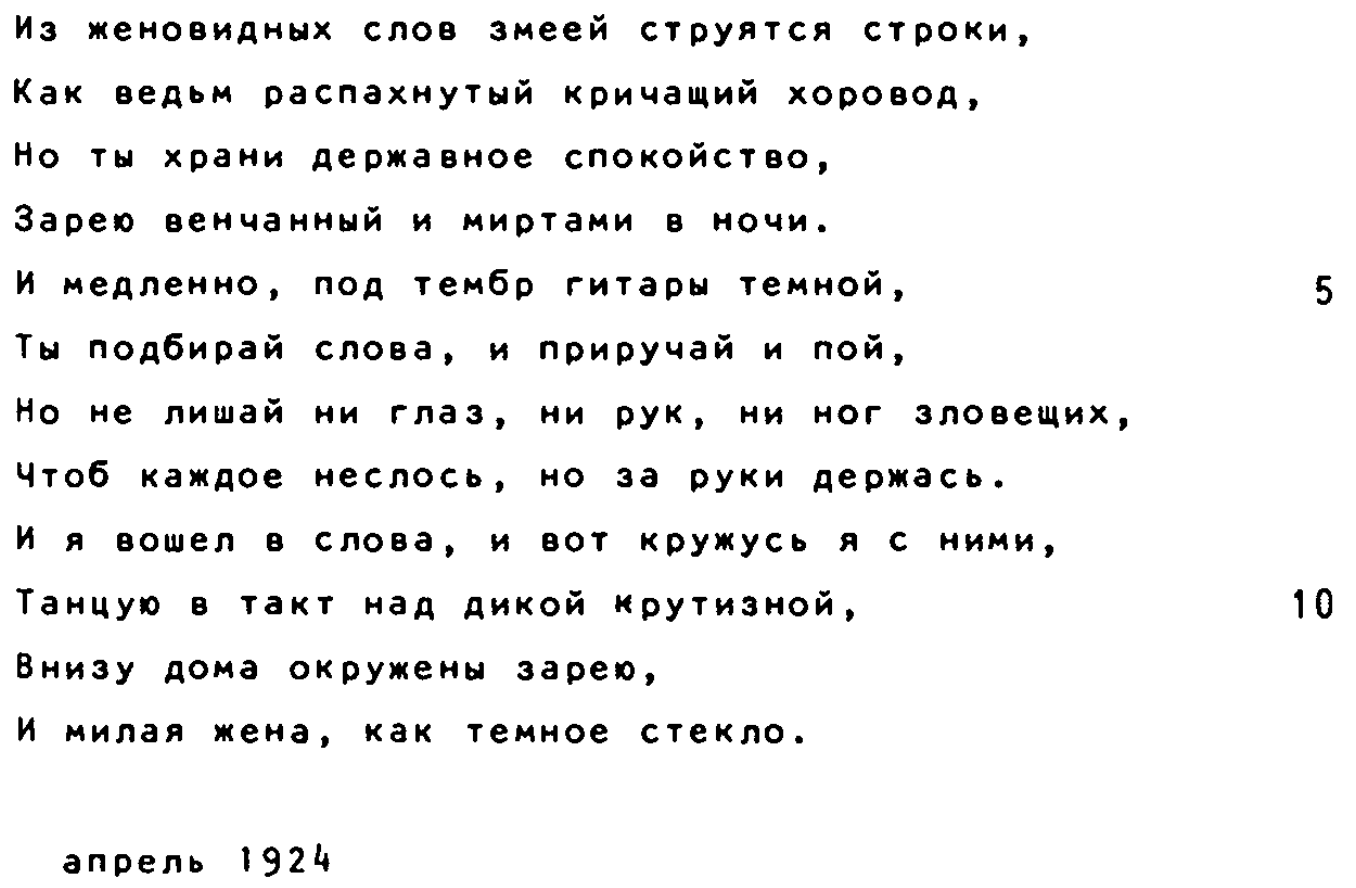


Под лихолетьем одичалым,

СреАи проулков Городских

Oн еле видной плоской теньо

BАDУГ ПрОскоЛЬзнУЛ И ГОВОРИт:

"Mне вспихивать, аругим - сиянье.

Но вспыхиванье - суета.

Я оборвался средь зияний,

Ао вас разверзлась жизнь моя."

И тихий шопот плшл ПОА Аубом,

И семиградный встал слепеи,

Заговорил в домашнем круге

0 apyre оности своей:

"Oн не Обуздан был среАЬ бАений

ПОА СНОВИАЕНВеM ГОРОАСКИМ,

Не жизнь ИСКал Он - СЛадкой доли

Жизнь Проводить среаи ночей."

anрель 1924 
8 одежде из старинных слов

Ha Фоне мраморного хора

Свой острый лик я погрузил в партер,

Но лилия явилась мне из хора.

в ее глазах дрожала глубина

И стук сиял домашнего вязанья.

A на rope Фонтана красный блеск,

उаученное мacok rorotahbe.

и жизнь предстала садом мне,

Увы, не пынным польским садом.

h ваступа木 из колонн

Моих ночей мрачноречивых.

Но как мне жить средь лодных очагов,

В плане трагическом героя,

с привнчкор все отступать назад

Ha два wara с откинутой спиною.

aпрель 1924 
Поззия есть Аар в темнице ночИ струнной,

Пылахщий, нежданный и глухой.

Природа мудрая всего меня лишила,

Таланты шумные, как серебро взяла.

И я, из башни свесившись в пустыно,

Припоминар лестницу в чвету,

По ней взбирался я со скрипкой многотруаной,

Чтоб волнами И миром управлять.

Так в оности стремился я к безумьо,

Загнал в глухур темь познание мое,

Чтобы цветок поэзии прекрасной

Питался им, Как почвор родной.

сентябрь 1924 
ОТШЕ ЛЬНИКИ

Отшельники, тристаны и позты,

Пнлариие силой вещества -

Три разных рукава в снуощих дебрях мира,

Прикованных к Ластящемуся яну.

Среди лодей я плыл по моро жизни,

Держа в uеnях кричащуо тоску;

хотел забыться я у ног любви жемчужной,

Сидел смеясь на днище корабля.

Но день за днем стущалось оперенье

крылатых туч над головой тройной.

Корон златых ${ }^{1}$ все тише шелестенье,

Среди пустын вдруг очутился

И слышу песнь среди руин высоких,

Среди колонн без лавра и площа: 2

"Пустынна жизнь среди Пальмир несчастных,

rae moлодость как винотрая цвела

В руках умелых садовода

Без лиц в трех лицах божества.

в ero садах необозримых

Неутолимы и ясны

Выходят из развалин пары

и вспихиварт на noporax mrлы.

И только столб стоит в пустыне

3 тятелом пурпуре зари

1 бородой Эрот итрает,

<опнтиами nереступает

tа барельефе у земли." 3

ПараФраза вместо "вершины (кроны) деревьев, освещенные солнием."

: Эro noer nepвaя исnocracb ero - nozt.

: На барельефе изображен Эрот, ставший сатиром. Не так ли выротдается любовь? 
He растворяй в сыруі ночь, Геката,

Среди пустынь пустуо жизнь влачу,

Как изваяния, слова сияят со мноп

желанней пиршества и тише пирамия.

И вUступает ГОроА многолодный

И рынок спит в ОбъЯтьях тишины,

Средь антикваров желчных говоро я:

"Пустынных ФОрм томительно ищу."

Смолкает песнь, Тристан рыдает

B расщелине у драгоиенных плит:

"О, Аля того-ль Изольды сердие

Лежало на моей груди,

Чтобы она, как Филомела,

взлетела в капище любви,

чтобы она прекрасной птицей

Кричала на ночных брегах..."

Пересекает голос лысый

Из кельи над рекой пустой:

"Не вожаелел красот я мира,

Мой кабинет был остеклен,

За ними книги в пасти черной,

За книгами - сырая мгла.

Но все ке я искал названий

и пустоту обогащал,

Наследник темный схимы темной,

Сухой и бледный, как монах.

С супругой нежной в жар вечерний

я не спускался в сад любви..."

Hо вuступает столб в пустыне,

Шаги из келии ушли

и в отдаленных переходах

Ha разрисованных цветах

Пространство музыкой светилось, 
Как буато поланем озарилась

Невияимой, но ощутимой речь: ${ }^{4}$

"Когаa из волн я восходила

На итальянские поля...

Но здесь нежданно я нашла

Oстаток сына в прежнем зале.

Он красен был и молчалив,

Koraa ero я поднимала,

И ни куарей и ни чела,

Но все же крылышки Арожали."

И появившись вдалеке

в плаще багровом, в ризе синей,

Седые космы распустив,

Она исчезла средь пустыни.

И смолкло все.Как лепка рук умелшх:

тристан в расщелине лежит,

Отшельник Аремлет в келье книжной,

Позт кричит, окаменев.

Зеленых крон все громче шелестенье.

На уличе у растопнренных громад

Очнулся а.Прехояит час весенний,

Свершенний день раскрылся у ворот.

Май-ОКтябрь 1924

4 Слышится голос невидимой Венеры, она вспоминает, как вторично рождалась на берегах Италии (Боттичелли и пр.) 
Оано неровное мгновенье

ПОА рОвн世м ОКОМ бUтия

Coepwar путь a по пустнне,

Где искушает скорбь меня.

8 шатрах скользящих свет не гаснет,

$n$ от зари и до зари

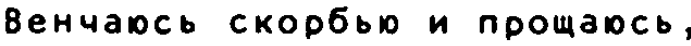

И вновь венчаDCb до зари.

KaK будто скорбь владеет MHOD,

Mахнет платком - и я у ног,

И чувствуо: За поцелуй еаиный

Я первородством пренебрег.

сентя6рь 1924 
AHAXAPЗ

ПОА ЧУАОТВОРНИМ НЕЖHНM ЗВОНОМ

Игральнах слов стор опять.

Полудремотное существованье -

Вот, Что осталось от меня.

Так сумасшедший собирает

осколки, камешки, сучки,

Переменясь, располагает

и слушает остатки чувств.

И каждый камешек напоминает

Eму - то тихий говор хат,

То громкие палаты дожей,

Быть может, первую любовь

Среаь петербургских улиц шумных,

Koraа варуг вымирал проспект,

И Он С ПОАРугой многогульной

Который раз свой совершал пробег,

06еспокоен смутным страхом,

Рассветом, детством и луной.

Но снова ночь блатоухает,

Янтарным анмом полон Крым,

Фонтаны борт и музика пылает,

И нереиян легкие резвятся перед ним.

ОКтябDЬ 1924 
Не тщись, художник, к совершенству,

Поднять резец искривленной рукой,

Но выточи его, покрой изящным златом

И со статуей рядом положи.

И матнетически притянутые взоры

Тебя не проглядят о разубранном резие,

А статуя под покрывалом темным

B венце домов останется monuato.

Но прилетят года, резец твой потускнеет,

Проснется статуя и скинет темный плащ

и, патетически перенимая плач,

Затоворит, притягивая взоры.

октябрь 1924 
0 , сколько лет я превращался в зхо,

В стоящий вихрь развалин теневых.

Теперь я вырвался, свободный и скользящий,

я на балкон взошел, где оность начинал.

И снова стрелы улиц освещенных

Марионетную толпу струили подо мной.

И мне казалось, в этот час отвесный

Я символистом свесился во мглу,

Седнм и пережившим становленье.

и оперяюии опять глаза свои,

и одиночество при свете лампы ясной,

Когда не ждешь восторженных друзей,

Когда поклонницы стареощей оравой

Ha креслах наступившее хулят.

нет, я другой. Хивое начертанье

Bо мне pacter, kak зарево.

я миру показать обязан

вступление зари в еще живые ночи.

дека6рь 1924 
Да, целый год я взвешивал,

Hо не понять мне moero искусства.

Уже в садах осенняя прохлада,

И дети новые Арузей вокруг меня.

Испитывал я тщетно книти

B nepramentax суровых и новые

Со свежей типографской краской.

в одних наитие, в других же - сочетанье,

расположение - поззией зовется.

Hнorá

Больница для ума лишенных снится мне,

чаще сая и беззаботное чириканье,

Равно невнносимы сни.

Hо забыварсь часто, попрежнему

Бессмысленно хватар я бумагу -

И в xасе заметное стущенье,

И быстрое двитенье злементов,

И Образы под яростным Лучом -

Hа миг. И все опять исчезло.

Хотел бы бать ученым, постепенно

Он мнСль свов доводит до конца.

А нам одно блестящее мгновенье,

И упражненье месячы и годы,

Как в освещенном плещущей луной

Mонастыре.

Пастушья сумка, заячья капустка,

окно с решеткой, за решеткой свет

Bо тьме повис.И снова я пытарсы

восстановить утраченнуо पепь,

Звено в звено медлительно вдевар.

И кажется, что знал я все

B растраченные оношества годы.

Умолк на холмах колокольный звон,

Покойников ХОРОнят ранним Утром,

Без отпеваний горестных и трудных,

Как будто их субстаниии хранятся 
И3 DOAa в род в телах живыX.

В своей 6иблиотеке позлащенной

Cлежу за хороводами народов

h между строк прочитывар книги,

Халдейскоп наукой увлечен.

И тот же өорон черный на столе,

Предвестник и водитель Аполлона.

Но из АОмов трУАОЛюбивы шу шу

paccensaet сумрак и тревогу.

И новый быт слагается,

Совсем аругие песни

Поптся в сумерках в однозтажных rородах.

Встарт с зарей и с верой в первородство,

Готовятся спокойно управлять

До наступленья золотого века.

И принужденье постепенно ниспадает,

И в пеленах проснулося дитя,

Кричит оно, старушку забавляя,

и пляшет старая с толпов молодой. 
BOPOH

Прекрасен, как ворон, стою в вышине,

выпуклы архаически очи.

Вот ветку прибило, вот труп принесло.

и снова тина и камни.

и, важно ступая, спускарсы со скал

И в очи свой клюв погружаю.

И ЧУАИтСя мне, Что Я ПЬю ЯСный СОК,

4 то 6абочкой переливансь.

คнварь 1926 
На крышке гроба Прокна

Зовет всD HOUь сестрУ CBOD,

в темнице Филомела.

Hи петь, ни прясть, ни освещать

Уже ей в отчем доме.

Закрыты Авери на запор,

А за дверьми Аозоры.

И постепенно, день за анем

Слова позабывает,

И пеньем освещает мрак

И звуками играет.

Korá же вновь открылась аверь,

Услышали посланцы,

Как колыханье волн ночных,

Бессмысленное пенье.

山ебечет Прокна и взлетает

В Лазури яснОЙ ПОА ОКНОМ.

А соловей Полночный тает

На птичьем языке своем.

1926 
И снова мне мерещилась любовь

На Аиком Ане.в взвивающемся сөисте,

К ней все мы шли. Но берета росли.

Любви мы выше оказались.

И кажднй, вниз бросая образ свой,

Ero с собой мелояией связуя,

Стоял на берегу, растущем в высоту,

Своим же образом иаруем.

1926 
Нар миром ршсцой торопливой

Бегу я спокоен и тих.

Как буато обтеиь я обязан

И кажауг вещь осмотреть.

И мимо мелькапт И вьотся,

Заметно к могилам спеша,

B обратнуо сторону тени

Когда-то любимых лодей.

Из оноши дух вw6егает,

А тело, старея, живет,

А девушки синие очи

За нељ, Как глупость, Иаут.

1926 
В стремящейся стране, в определенный час

Себя я на пиру встречар,

Koraа огни застигнуты зарей

И, как цветы, заметно увядают.

Иносказаньем кажется тогда

Ночь, и заря, и Ауновенье,

И горький парус вдалеке,

И птиц сиярщее пенье.

1926 
З ВРИДИКА

Зарею лунною, когда я спал, я вышел, Оставив спать свой образ на земле.

Ная ним шумел листвою переливной

Пустынный Парк военныХ яней.

Куаа итти легчайшими ногами?

Зачем смотреть сквозь веки на поля?

Но музыкоп из тумана

Передо мной возникла голова.

Ee rлaza струились,

И губы белые влекли,

И волосы сияньем извивались

Ная чернотой отсутствуощих плеч.

И обожгло: ужели Эерияикой

Искусство стало, чтоб являться нам,

Pассеянному поколению орфеев,

живущему лишь по ночам.

1926 


\section{ПСИХЕя}

Любовь - зто вечная оность.

Спит замок Литовский во мгле.

Канал проплывает и вьется,

Ная замком притушенный свет.

И кажется солнцем встариим

Психея на дальнем коние,

где тоже канал проплывает

В досчатой orpane своей.

1926 
Tебе примерещился Город,

Весь залитый светом аневным,

И шелковый плат в тихом доме,

И родственников голоса.

Быть может, сочные луны

Mерцарт плодов над рекой,

быть может, яснуо зрелость

Напрасно мы ищем с тобой!

все так же, почти насмехаясь,

Года за годами петят,

Прекрасные очи подруги

Bce tak we в пространство глядят.

мне ито - повернусь, не замеиу,

Kak ГоA пролетел и norac.

Но аля нее иветы иветут,

K Иветам идет она.

И B noaheбecon ronoca

и roлoca в траве.

1926 
я восполненья не искал.

8 своем пространстве

я видел образ женщины, она

С личом, как виноград, полупрозрачным,

росла со мной и пела и цвела.

Я уменьшал себя и отправлял свой образ

На встречу с ней в глубокой тишине.

я - часть себя. И страшно и пустинно.

я от себя свой образ отделил.

Как листья скорчились и смались миФы.

Идололатрией в последний раз звеня,

На 6рег один, без Эвридики,

Сквозь Ахеронт пронесся $\boldsymbol{R}$.

1926 
$\mathrm{HO4b}$

И мы no onycteвшемy napkety

Подходим к просветлевшим зеркалам.

Спит саА, покинутый толпоо,

Среди дубов осина чуть дрожит

и лунный луч, земли не достигая,

Mем туч висит.

И в глубине, в переливариемся зале,

Танцуот, ХОАят, ГОворят.

ОАИн сквозь ручку к даме гнется,

Аругой медлительно следит

За собственным отображеньем,

А третий у камина спит

14 видит Рима разрушенье.

И ночь на napycax стремится,

И самовольное встает

กолулетящее виденье:

- Cредь вас а Феникс одряхлевший.

В который раз, ПоА Аивной глубиной

Неистребимая, я на костре воскресну,

Но вн погибнете со мной. -

- Спокойны мы, за огненной заставой

Ты временно забудешь нас.

Не в глубине глухих пещер

Стоит твое изображенье,

Оно развеяно везде

И связано С тобор нераздельно,

Куда 6 не залетела ты

Ты свой состав не переменишь.

Сквозь дым и жар Психея слышит

Далекий погребальный звон.

Ей камется - огонь чуmое тело ломит.

กред нер виступает мир

Cперва в однообразии прозрачном. 
МУЗЫKА

в книговращалищах летят слова.

В словохранилищах блуждар я.

варуг слово запоет, как соловей -

я к лестнице бегу скорей,

И ПРЕАО МНОО СЛОВО ТОЧнО КОРИАОР,

Как путешествие ПоА бурною луною

из мрака в свет, со скал береговых

На моря беспредельный перелив.

He в звуках музыка - она

во измененьи образов заключена

Hи O, ни $A$, ни звук иной

Ничто пред музыкой такой.

Читаешь книту - варуг поет

НеобъяснимЫЙ ХОРОВОА,

И хочется смеятьСЯ Мне

B нежданном И весеннем ане.

1926 
За ночbl ночb nyctb onaдaet,

Мой аруг в луне

Сияит и в зеркало глядится.

А за окном свеча двоится

и зеркало висит, как птица,

Meж звеза и туи.

"O, вспомни, милый, как бывало

Во Ани раздоров И войнष

Ты пел, взбегая на ступени

Прозрачных зааний ная Невой."

И очи шире раскршвая,

Плечами вздрогнет, подойдет.

и серяче, в Флейту превращаясь,

Ун世вно в комнате noet.

А за окном свеча бледнеет

И утро cepoe встает.

B соседних комнатах чиханье,

neperopoдок колиханье

И вот уже трамвай ияет.

1926 


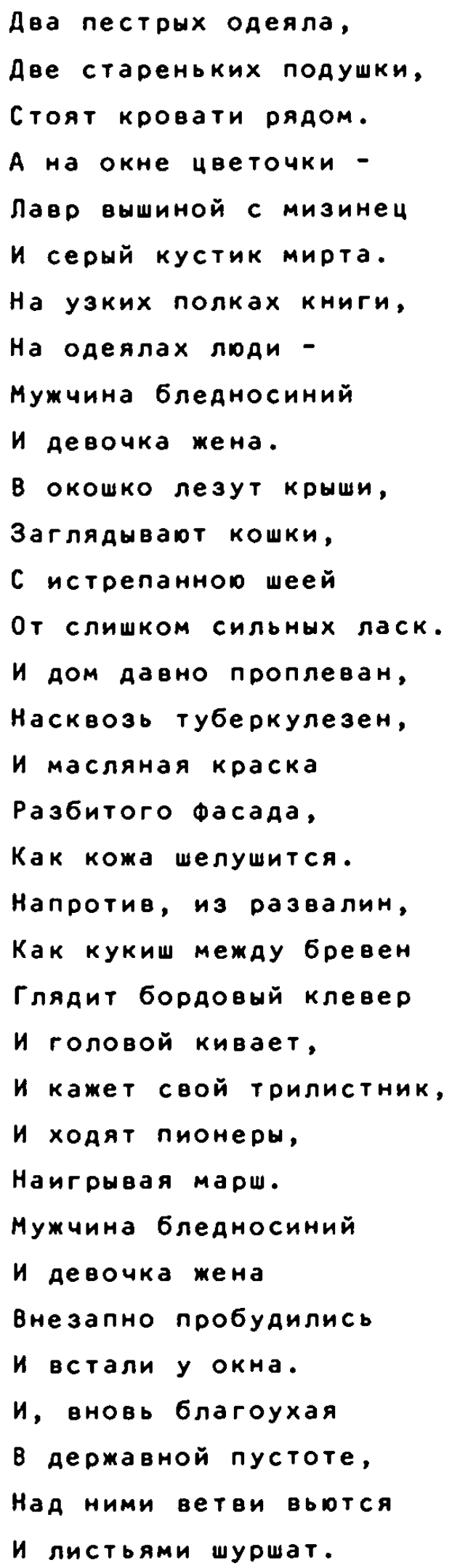

Наигрывая марш.

Мужчина бледносиний

И девочка мена

внезапно пробудились

И встали у окна.

И, вновь благоухая

8 державной пустоте,

Над ними ветөи вьотся

И листьями шуршат. 
И вновь она Психеей

СКлоняется ная ним,

И вновь ОнИ С чветами

Гуляют вдоль реки.

Дома любовьо стонут

В прекрасной тишине,

И окна все раскрыты

НаA золотой водой.

Пактол ли то стремится?

Не СарАн ЛИ СТОят?

Иль брег алексанарийский?

ИЛЬ этО РИМСКИЙ СаА?

Hо голоса умолкли.

И АОжаИк моросИт.

Tenepb Они выходят

В туманный Ленинтрая.

HO ИнOГAа весHOD

НисходИт 6латодать:

И вновь аля них не льяины,

А лебеаи пльвут,

И месяи освещает

Пактолом зимний Путь.

1926 


\section{элЛинисть}

Мы, эллинисты, зАесь толпой

В листве шумящей, ваоль реки,

Порхаем, словно мотнльки.

На тонких ножках голова,

На тонких шечках синева.

Блестяш И звонок Аам наряа,

Фонтан世 боDT, OГни Горят,

За парой парор скользим

И впереди наш танцевод

Ступает задом наперед.

И волхвованье СЛОв ПОА выпуклой луной

И образы людей исчезли предо мной,

И снова виплил танцевод.

За ним толпа ГУСьКом Идет.

$И$ He noppyra - rocnowa

За ручку каждого ведет

И КаЖАНЙ ПесенКУ ПОет:

"Проходит ночь,

УХОАИм ПрОчь

B cBon homa,

в подвалы.

А с вышины,

Из глубины

Густих паров,

ГЛЯАИт ЛЮбОвь

И движет солнием

и землей,

Зеленокраснор луной,

ЗеленОкраснОо водор."

1926 
Мрак побелел, бледнели лица

Полуоставшихся Гостей.

Казалось, город просыпался

Еще ненумней и бойчей.

ПреА вознесенской Клеопатрой

Он опьянение прервал,

Eго товарищ на Аиване

Oпустошенный засыпал.

И женщина огромной теньо,

Как ияол, высилась меж них,

Чуть шевеля пахучей тканьо

На красной пола желтизне.

А на столе сиял, как перстень,

Еще не допитый Глоток.

Символ не-вечности ИСКУсства

Быть опьяненными всета丿.

1926 


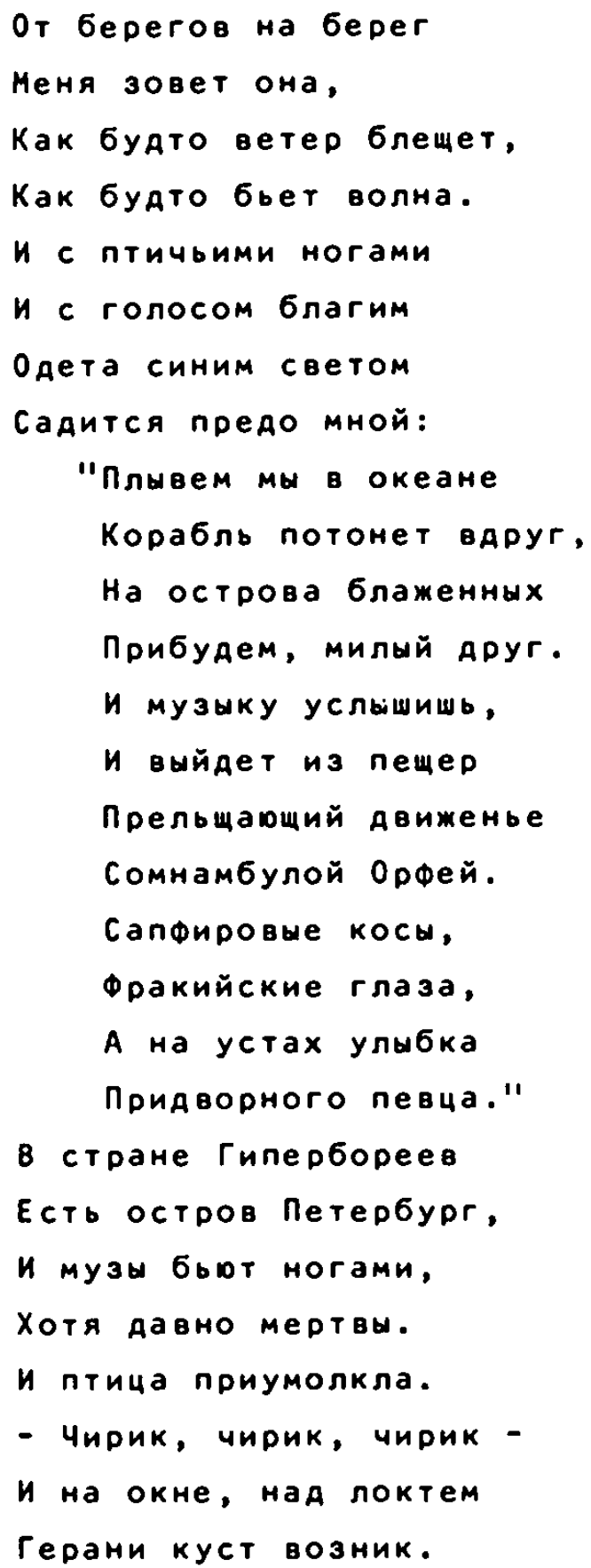

1926 


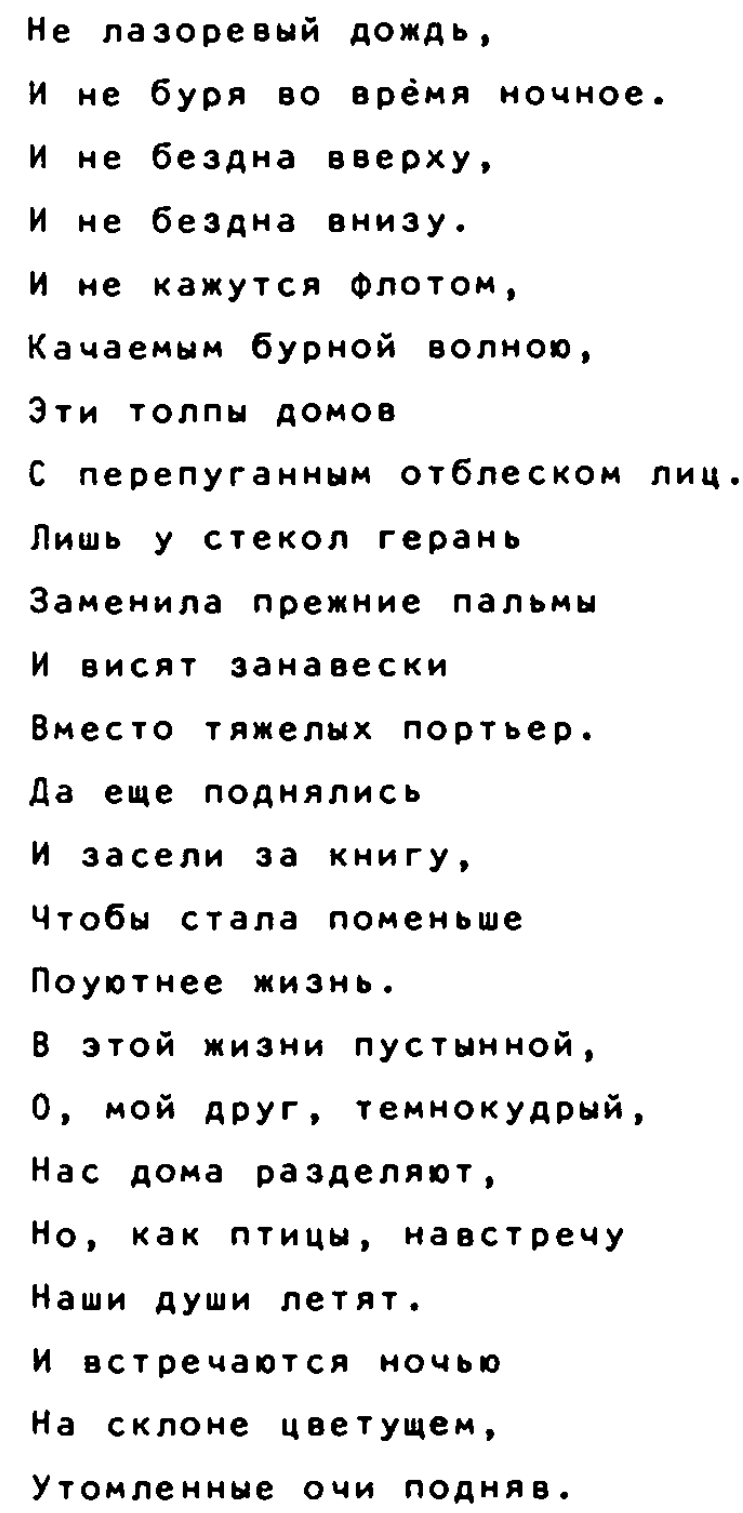

1926 


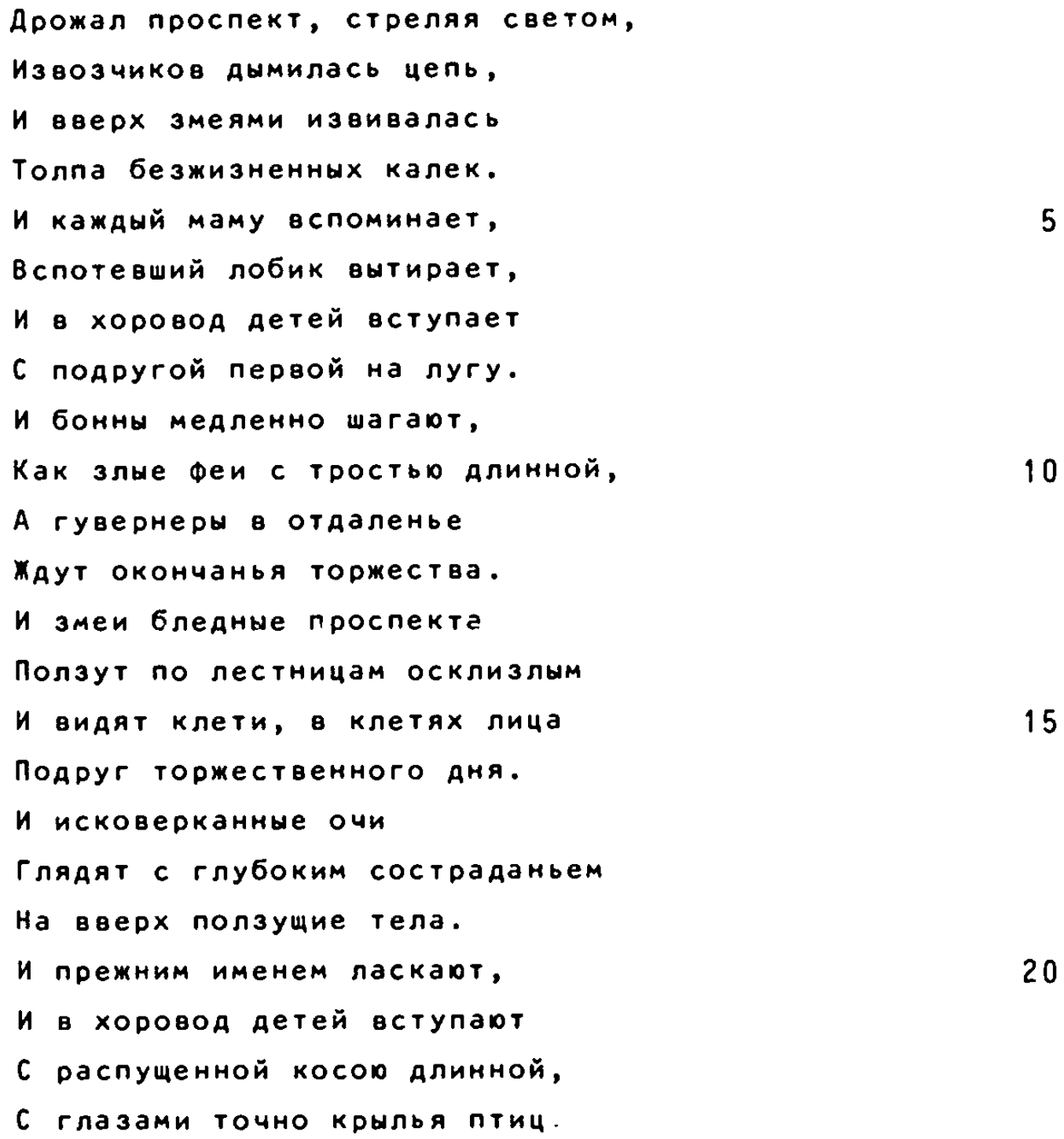

A гувернеры в отдаленье

Маут окончанья торжества.

и змеи 6 леднше проспекта

Ползут по лестницам осклизлым

и вияят клети, в клетях лица

Подруг торжественного аня.

И исковерканные очи

Гляяят с глубоким состраданьем

на вверх ползучие тела.

И прежним именем паскарт,

И в хоровод детей вступают

C распущенной косою Алинной,

С глазами точно крылья птиц.

1926 


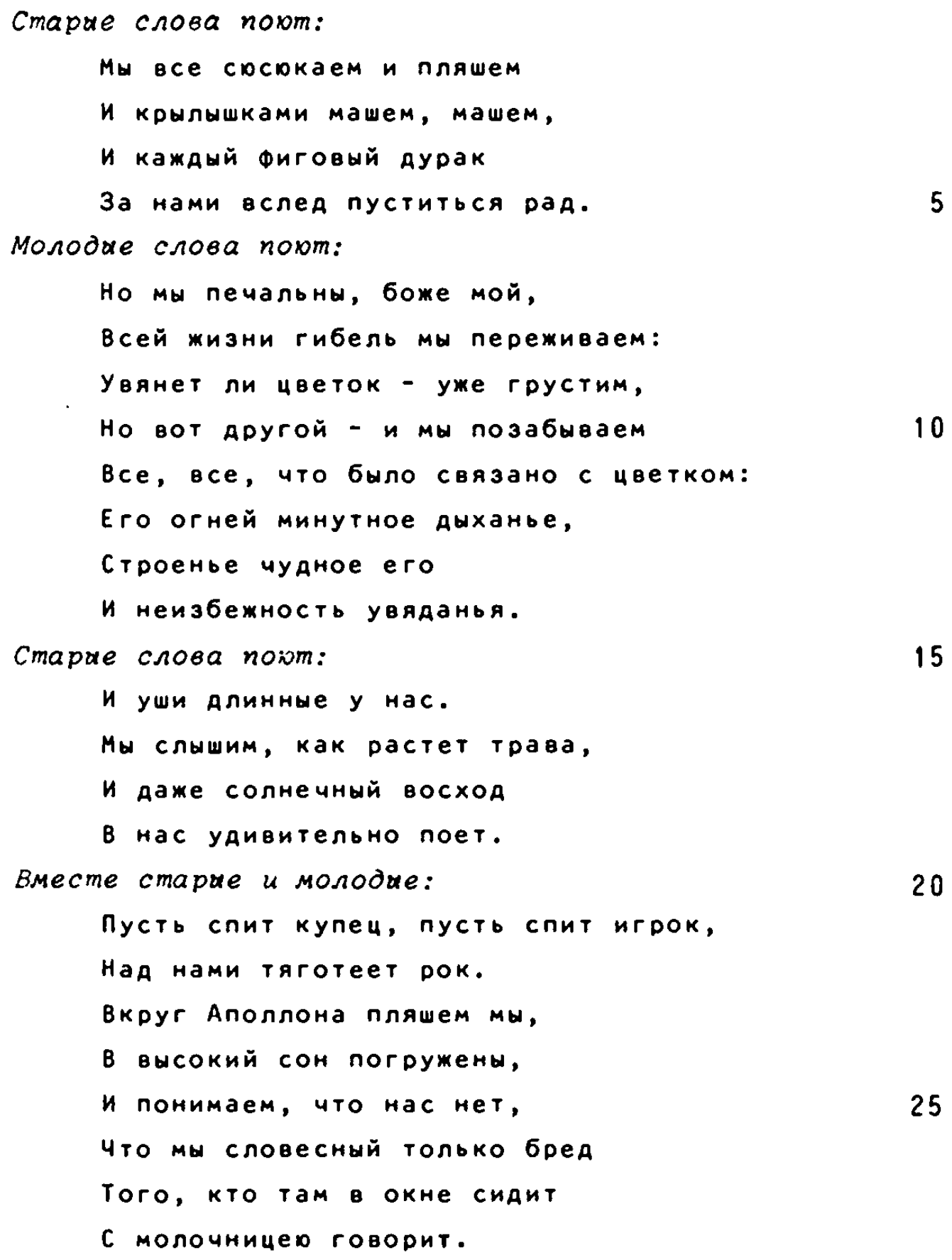

И уши Алинные у нас.

Мн слышим, как растет трава,

И Ааже солнечный восхоА

В нас уаивительно поет.

Bмecme cmapue u молоdue:

Пусть спит купеи, пусть спит итрок,

Hад нами тяготеет рок.

Bкруг Аполлона пляшем мш,

В внсокий сон погруженн,

И понимаем, что нас нет,

पто мы словесный только бреА

TORO, Кто там В OKHе СИAит

C Mолочничет говорит. 
Я девой нежнор была,

Шлейф смысла за собой вела.

Лобовь - вскричали мотыльки

и пали ниц, как васильки.

и слово за строкой плывет,

Bapyг повернется и уйдет.

Затем Появится опять,

Возьми его и будешь тать,

Что взять никак не мог вcero,

И ВзяЛ, ЧтО ГОАНО АЛя HеRO. 
Слово о театралоном костиме:

Mне хорошо в сыруо ночь

БЛУжАаTЬ И ГаснУТЬ НаA ВОАОЙ

И аумать О суаьбе иной,

Когда одет пыльцею был,

Когда Аругих произносил

Таких же точно мотнльков

B прах разодетых Аурачков.

Дай ручку, слово, раз, Ава, три!

Хожу с тобор по земле.

За мнор шествуот слова

И крылышкИ Арожат еАва.

Как бУАТО бЫ амурОв рОЙ

Иает во Глубине ночной.

Kуда идет? Koro ведет?

И Аля него опять noet?

И тонкий Аым И легкий страх

я чувствуо в своих rлaзax.

И вижу, вижу маскарад.

Слова на полочках стоят -

Оано овето, точно

Aругое - как лакей ЕвграФ,

А третье - верный архаизм -

Скользит как будто бы трокизм,

Таниует в такт И вниз гляAит. 
Там в городе бежит река,

Целуотся два голубка,

Милиционер, зевнув, ияет

И смотоит, Как вода плывет.

Ero nодруга, как луна -

Ее изогнута спина,

Интеллигентен, тих и иист,

Смотро, как дремлет букинист.

в подвале сыро и темно,

Семь полок, лестница, окно.

Но что мне делать в вышине,

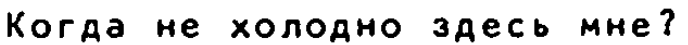

उдесь запах книт,

Здесь стук жуков,

Как буато тиканье часов.

उдесь время снизу жрет слова,

А наверху ияет 6орьба.

1927 
Слова из пепла слепок,

Cтол $а$ у пруат,

Ко мне идет натая

ВСЯ МОЛОАОСТЬ МОЯ.

Фальшивенький веночек

надвинула на лоб.

Невинненький АРУжочек

Передо мной встает.

Он боязлив и страшен,

Meptвa ero aywa,

Невинными словами

Она извлечена.

Он молит, умоляет,

Чтоб аушу я вернул.-

я молоя был, спокоен,

Души я не вернул.

Любил я слово к слову

Нежданно приставлят,

Гадать, ито зто значит,

и снова расставлять.

Я очень удивился:

- Ho nочемy, мой аруг,

я npocto rak, nгpan,

$x$ чему такой nспуг?

Tеперь опять явился

Tереа моим окном:

tашел я место в мире,

ииву в без души.

1ришел тебя проведать

не изменился-ль ты? 
ЗBУKONOAOEИE

Konstantin K. Vaginov - 9783954794300 
Черно бесконечное утро,

Как слезы стоят Фонари.

Пурпурные, гулкие звуки

Слышны отдаленной зари.

И слово горит и темнеет

На площаяи перед окном,

и каркаот птицн и реот

Hад черным его забштьем. 
Hет, не расстался я c roбon.

Ты попрежнему ликуешь

Сияньем ненаглядных глаз.

Но не прохлаяная Фиалка,

Hе розы, точно ветерок,

Ты восстаешь в долине жаркой,

И пламя лижет твой венок.

И все, что ты а себе хранила

И, как зеницу, берегла,

Как уголь черный и невзрачный

Ты будущему отдала.

Hо в стороне,

Гае Аым клубится,

Но в тишине

Растут цветы,

Порхают легкие певичы,

Арожат зеленые листы. 


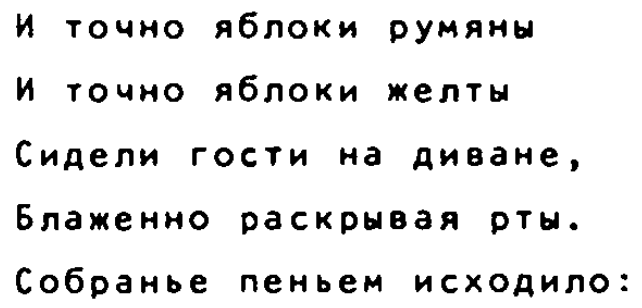

Cnepвa madame за ним ходила, Потом monsieur eе сменил...

Декольтированная Аама,

Как непонятный сФинкс, стояла,

она держала абажур,

На нем Психея и Амур.

Из толя нежные цветочки

и просто бархатные точки.

Стол бал ни беден, ни богат.

Картофельный белел салат.

И соловей из каждой ромки

Стремглав за соловьем летел.

Раскланиваясь грациозно,

Старик пленительно запел:

Зачем тревожишь ночьо лунной

Любовь и MOЛодость MON?

ВеАЬ АевУшкОD ЛеГКОСТРУннОЙ

Своей Ауши не назову.

Она веселая не знала,

Что ей погибель суждена.

И виноград арузьям срывала.

Вакханкой томною плясала,

И радостная восклицала:

- АХ, я пьяна, совсем пьяна!

И полюбила возноситься,

Своео легкостьо кичиться,

Пчелой жужжащею летать,

Безмолвной бабочкой порхать...

и вдруг на лестнице стоять. 


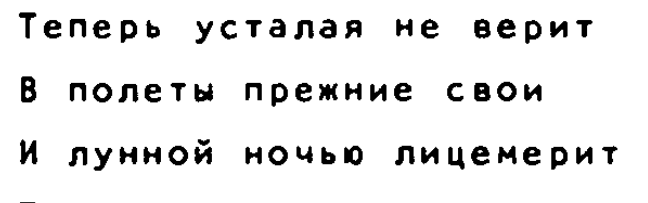

там, где свистали соловьи.

Старик пригубил.

Смутно было.

Луна над облаком всходила.

и стало страшно, что не хватит

Вина средь ночи. 


\section{голOC}

Столица глядела

Развалиной.

Грамданская война летела

Волной.

и нэп сошел и развалился

B roctином nectpon ayroñ.

Самодовольннми шарами

Шли пары толстые.

И бриллиантами качали

$B$ yuax.

и заедали анекдотом

и запивали оnереттой

Борь6y.

B ctekso nрозранное одети,

0гни мериали.

растратн, взятки и вино

Неслись, играя в домино.

Волнуощий и шелестящий

и бледногубый roлoc nen,

что чести нет.

И появляся в кабинете

8 бобры магчайшие одет:

И npeвpamancя в pectopaнe

Oн в снотсшибательный обед.

И ночьо, в музыкальном баре

Наряяной девоп звучал

И изворотливость веселур,

Как победителя ласкал. 
Психея дивная,

Где крылья rony6ue

$h$ nerkne rлasa

И косн золотне.

Как страшен взгляд очей испепеленной,

B просторы чистые попрежнему влюбленной,

В ужасный лес вступила жизнь твоя.

Сожженная, ты вспыхивать обречена

и легким огоньком то здесь, то там блумдаешь

и путников средь ночи увлекаешь. 
HAPUИCC

Он не был пьян, он не был болен -

OH просто встретил сам себя

У Фабрики, где колокольня

8 обсерваторио превращена.

8 нем было тускло и спокойно

И не хотелось говорить.

Не останавливаяс, хладнокровно,

Пошел он по теченьо плыть.

Они расстались, но встречались

Из ГОАа в ГОА.Без лишних слов

неловко головой качали.

Прошла и пность и любовь. 
Золотие глаза,

Точно множество тусклых зеркал,

Подымает прекрасная птича.

Сквозь туманы и сөисты дожая

Голубые несутся просторы.

ПОявились ПОА ТеМнММ ДОЖАеМ

Ава крыла быстролетной певицы,

И томимый голос зажег

Бесконечно утлые лица.

И запели пленительно вдруг

в обветшалых телах, точно в клетках,

Соловьи об убитой любви

и о встречах, губительно редких. 
Bс⿰ ночь मома дышали светом,

Becb rород nen в сияньи огневом,

Снег падал с кршш, теплом домов corpetwй;

Невзрачншй человек ншрнул в широкий дом.

Oн, как и все, бшл утомлен разлукой

С своей Аушой,

Он, как и все, боролся с зябкой скукой

и пустотой.

Пленительны предутренние звуки,

Hо оности второй Он тщетно ждет.

И вместо Аивных мук - разуверенья муки

Bokpyr hero, как дикий саA, растут. 
Ha набережной рассвет

Сиреневнй и неясный.

Плешивые дети сияят

На великолепной вершине.

Быть может то облеск окон

Им плечи и грудь освещает,

Но бледен, как лист, небосклон

и музыка не играет. 
Русалка пела, дичь ждала,

Сидели гости у костра,

На нежной палевой волне

Чорт ехал, точно на коне.

Мне милый Аруг сказал тогАа:

- Cияеть приятно у костра.

Как ХOРОшо среАИ лодей

Лишь видеть нежных лебедей.

Зачем ты музыку прервал? -

Мучительно Он продолтал.

- Из круга вышел ты, мой аруг,

Tеперь чертям ты первый друг.

Bкруг сосен майские жуки

ведут воздушнЫй ХОРОвод.

Hа холмах дачные огни

вновь зажитает мотылек.

- Bернитесь, нимфы! - он вскричал, -

8ысокая мечта, вернись!

Зачем ты отнял жизнь мор

и norpyзил меня 80 тьму?

Вскочили гости: - Что опять?

Как непристойно приставать.

पего вам надо, жизнь проста.

Aа помиритесь, rocnosa. 
Oн С OHOCTbD сөоей, КаK Аолжно, распрощался

И двойника, как смерти, испугался.

Oн в круг вступил и, мглою окружен,

Услышал пред собой девятиструнный стон.

Ее лица не видел он,

Но чудилось - оно прекрасно,

И хор иветов и голоса Аверей

вливались в круг, объятый ночьо властной.

И появилось нежное лицо,

Как бы обөеянное сөетом.

Он чувствовал себа и камнем и сөинцом,

Oн ждал томительно рассвета. 
Преа Револючией громадной,

Как звезды, страны восстают.

Bgeraet herp.

Высокомерными глазами

Ero ауша окружена,

Гарлема Аикими ночами

она попрежнему пьяна.

Ero мечта: разгладить волос

И кожи ивет чтоб был белей,

Чтоб ласковый ликерный голос

Пел о любви.

Неясным Призраком Свободы

OH весь заполонен.

Вино и карты и блужданье

СвOбOAON CUИTаET OH.

Идет огромный по проспекту,

ГАе Головы стоят,

ГАе комсомольИ山, КомсомолкИ

ИаУт, КаК стРУнный ЛаА.

И TOCYATDCTBEHнOCTDD HOBOЙ

Гае человек горит,

Надемдоп неколебимой,

Что мир в ответ звучит. 
Kогаa Уснули все опять,

Мой Аруг чертей мне показал.

- Тебя люблю, - я отвечал, -

Хотел тебя я вознести,

в высокий храм перенести,

Но на пути ты изнемог,

Oт смеха адского продрот.

я бился, бился и взлетал,

C тобор вместе в ров упал.

Но будет, будет вновь полет.

В ночных рубашках мотыльки

Гасили в окнах огоньки. 
Кентаврами восходят Поколенья

и музыка гремит.

3а лесом там, летающее пенье,

Неясный мир лежит.

Кентавр, кентавр, зачем ты оглянулся,

Копыта приподняв?

зачем ты Флейту взял и заитрал разлуку,

волнуясь и кружась?

Веселья нету в жаркой бездне,

Кентавр, спеши.

Забудь; что был ты украшеньем,

или не можешь ты?

Иль создан ты стоять на камне

и coзepuatb

Себя и мир и звезд движенье

И размышлять. 
Он разлюбил себя, он вышел в непогоду.

Какое множество гуляет под дождем народу.

Как песик вертится и жалко и пестро!

в витрине возлежит огромное nepo.

Он спину повернул, пошел через дорогу,

Он к скверу подошел с решеткор убогой,

Где зелень нежная без сөета фонарей

Казалась черною, как өысота над ней.

Но музыка нежданная раздалась

И Флейта мирная поя лампой показалась,

Затем рояля угол и рука

Mrpaвuero, как дева, старика.

Гулявший медленно от зелени отходит

И взором улицу бегущую обводит.

Oн погружается все глубже в мепогоду,

Любовь он потерял, он потерял свободу. 
Прекрасен мир не в прозе полудикой,

Где вместо музыки раздался голос Аикий,

От оности предшествует Авойник,

что выше нас $и$, как звезда, велик.

Но есть двойник другой, его враждебна сила,

He впереди ero душа носилась.

กлетется он за нами по пятам,

Средь бела дня подводит к зеркалам

4 реш ведет за нас с усмешкон веселой

И, за руку беря, ведет дорогой голой. 
B повншенном rope

Hа крышах природы

Bедут музиканты

Cвоп хороводы.

Внизу обезьяны,

ритма he слыша,

Пляшут и вортся

Томно И скушно.

И те же реченья

И те же сомненья,

Как бУАто, Как бУАто!

По градам и весям

OHИ завыва⿴囗十

И нежно и сладко

Себя уважают. 
Какор прихотьо глупейшей

Казалась музыка ему.

Сидел он праздный и нахальный,

Следил, как пиво пьот в углу.

Cтал непонятен ronoc mоря,

Вся жизнь казалась ни к чему.

Он вспоминал - все было ясно,

И АЛИннМЙ, АЛИннАЙ КОРИАОР,

Там в глубине сая сладкогласный,

y ноr подруг Психеи ясной

Стоит лодей тревожншй хор.

как отдаленное виденье,

БуФетчик, потом обливаясь,

Бокалы пеной наполнял,

Украдкой димом наслаждаясь,

Передник перед ним сновал.

Февраль 1930 
Хотел он, превращаясь в волны,

Cиренор 6 лестеть,

Hа берег пенистшй взбегая,

Разбиться и лететь,

Чтобш опять приподнимаясь,

С Аругой волной соединяясь,

Перегонять и петь,

В высокий сад глядеть.

Mapt 1930 
Уж день краснеЕт, точно но,

BCTaET HaA TOYKON BONDOC:

Зачем скитался ты и пел

и внзвать тень свор хотел?

Ha Gepera,

на облака

Ложится тень.

Уходит मень.

KaK ХОЛОАна вода ТВОЯ

Летейская!

Забыть и навсегда забыть

Лодей и птиц,

С подругой нежной не ходить

И чай не пить,

С Арузьями спор не заводить

В сентябрьской мгле

0 буаущем, что ждет всех нас

Здесь на земле.

MaPT 1930 
Oн С Камдым ГОАОМ Уменьшался

И высыхал

И горестно следил, как образ

За словом оживал.

C пером сидел он на постели

ПОА пOЛKOD СШрОй,

Петрарка, Фауст, иммортели

И мемуаров рой.

Там нимФы нежно ворковали

И шел городовой,

ВозЛюбленные ГОЛОАали

и хор спускался с rop.

0рфея погребали

И раздавался плач,

В чилиндре и перчатках

Серьезный шел палач.

Они ходили в гости

Сквозы nереплеты книт,

устранвали вместе

Ha острове пикник.

май 1930 
"Kaк maль", - подумалось ему. -

"Oсенний ветер... ночь roлубая...

Я разлобил свор весну.

Перед суанлищем позтов

Под Снемной вьотой я стоял,

И камдый был разнообразен,

И был как мивой металл.

Способен был соединиться

И золото, вобрав меня,

Готово было распуститься

Цветком прекрасным.

Пришла бы нежная пора

И с ней бы солние появилось,

И из иветка бы, как роса,

Mое дыханье удалилось! "

mapr 1931 


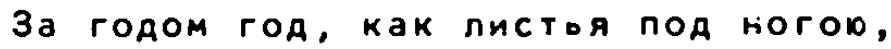

Становится желтее и печальней.

Прекрасной зелени никак не сохранить

И звона аивного любви первоначальной.

1 робость милая и голоса друзей,

Как звуки Флейт, уже воспоминанье.

вчерашний день терзает как музей,

гае слепки, копии и подыажанья.

Иаешь nо лестнице, но листья 3 а тобой

Сухой свой танец совершают

И ласковой, но черною порой,

как на театре хор, перебегарт.

aпрель 1931 
БАЛЛАДА

Звукоподобие проснулось,

Личом К позту повернулось

И медленно, как автомат,

Cказало:

Сегодня вставил ти глаза мне

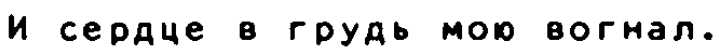

Уже я чувствуо желанье,

я, изваянье, перехожу в разряд людей.

И стану я, как вы, загадкой,

И буау изменяться я,

Хоть волосы mon he побелепт,

иначе буаут петь глаза.

Бнть momet стану g noxome

На жемчуг, потерявший цвет,

И полобить меня не смомет

Эпохи нашей человек.

Я ухожу, меня проклянешь

И постараешься отнять

rлаза психеи, сераце вннуть

и будешь в мастерскуо звать.

Tenepb врати мы. Безнадежно

- остановись! - воскликнешь тн.

Звукоподобие Aругое

Тн виставишь из темнотн.

Oно последует за мноп

БUt口 momet opar, 6Utb momet apyr,

Mш будем биться иль ликуя

Покажем мы потатье рук.

1932 
Почувствовал он боль, в Поток Лодей глядя,

Заметил женщину с личом карикатурным,

Как прошлое уже в ней узнавал

Неясность чувств и плеч скульптурность.

И острый взгляд и кожи блеск сухой.

Он постоял, но не окликнул.

Он чувствовал опять акачий цвет густой

И блеск дожая И воробьев чириканье.

И оживленье чувств, как крепкое вино,

в нем вызвало почти головокруженье,

Вновь человал он Горький нежный рот

И сераце, полное волненья.

Но аля аругого, может быть еще,

она цветет, она еще сияет,

И, может быть, тот золотым плечом

тень от плеча в истоме называет.

1933 
DXHAЯ HOUb

Как ночь бессонную зима напоминает.

и лица желтые, несвежие глаза.

И солниа луч природу обольиает,

Как незаслуженный и лучезарный взгляд.

Среди пытахщихся распуститься,

Средь почек обреченных он блуждал,

Сочувствие к обманутым растеньям

Надулось в нем, как парус, возросло.

А дикая зима все продолжалась, -

То падал снег, то дожды, как из ведра,

то солние принуждало распускаться,

А под окном - шакалы до утра

Здесь пели женщиной, там плакали ребенком,

варуг выли почерневшев вдовой.

и псы бездомные со всех сторон бемали

и возносили лай сторожевой.

Как ночь бессоннуо зима напоминает -

Камелии стоят, Фонарь слезу роняет. 
ПОАдеЛКИ онУо Любовь напоминают,

Глубокомнсленно на полочках стоят.

Tак немнне сердца кому-то подражарт,

Заемным опнтом Пнтартся сиять.

Но первая любовь, она благоухает,

Она, безумная, не хочет подрамать,

И копии и слепки разбивает

И пеньем наполняет берега.

Но копии, но слепки, точно Формн

Eе зовут, ее влекут.

उнакомое предстанет нзваяние,

КогАа в музей прохожие войдут.

1933 
Нора-ост гнул пальмы. мушмулу, маслины

И веллинттонио, как деву, колебал,

Ступеньки лестниц, словно пелерины,

К плечам пришиты были скал.

По берегу подземному 6лумдая,

Я встретил соловья, он подражал,

И статуо из солнечного края

Он голосом своим напоминал.

Я вышел на балкон подземного жилища,

Шел редкий снег, и плавала луна,

И ветер бил студеным кнутовищем,

Цветы и травы истязал.

Я понял, что попал в Элизиум кристальный,

Гае нет печали, нет любви,

Гае отраженьем ледяным И Аальним

Качаются беззвучно соловьи.

1933. Крым 
Вступил в Крыму в зеркальнуо прохлаяу,

ПОА градом желудей оркестр любовь играл.

И точно призраки со всех концов Совза

Стояли зрители и слушали Кармен.

Как ХОРОша Любовь в минУтУ Увяданья,

Невыносим знакомый голос твой,

Ту вечная, Как изваянье,

А слушатель томительно Аругой.

Он, как слепой, обходит сад зеленый

И трогает ужасно лепестки,

И в соловьиный мир, Поющий и влюбленный,

Хотел бЫ Он, КаК бЛУАн世й СЫн, ВОЙтИ.

декабрь 1933. Ялта 


\section{ЛEHИHГPAA}

Промозглий Питер легким и простым

Eмy в ту пору показался.

Под солнцем сладостным, ПОА небом Голубым

OH весь в прозрачности купался.

И липкость воздуха, и черные утра,

И фонари, стоящие, как слезы,

и липкотеплые ветра

Ему казались лепестками розы.

И Он стоял, И в северный цветок,

Как соловей, все более влоблялся,

И возаух за глотком Глоток

Он пил и улшбался.

И аумал: молодость пройдет,

Ауша предстанет 6езобразной

И почернеет, как цветок,

мир обведет потухшим глазом.

Холодный И Язвительный СТакан,

Быть может, выпить нам придется,

Ho все же роза с стебелька

Нет-нет и улшбнется.

Увы, никак не истребить

Виденье оности беспечной.

И ПрОАОлжает ОН Любить

Иветок прекрасный бесконечно.

январь 1934 
B аду прекрасные селенья

И Ауши не мертвн.

Но бестолковому Авиженьо

они обречены.

OHИ ХOTAT OбHяTЬ ADYR ADYTa,

Поговорить.

Hо вместо ласк посмотрят тупо

и ну грубить.

Февраль 1934 


\section{ПРИМЕЧАНИЯ}

Здесь публикуется первое собрание стихотворений К. Вагинова. После его смерти в 1934 году в Советском Совзе не вышел ни ояИн сборник его поззии. 8 США были переизданы Ава стереотипных сборника в издательстве "Ardis" (К. Вагинов, "Путешествие в хаос", Петербург 1921, Facsimile reedition, Ann Arbor 1972 и К. Barинов, Стихи, посвящ. А. Федоровой, Ленинграя 1926, Reprint, Ann Arbor 1978). B альманахе "Anoллон - 77"(Париж 1977) бнло nерепечатано большинство стихотворений иикла "Звукоподобие". Несколько отдельных стихотворений было помещено в разных сборниках.

8 собрании текстов и материалов о его творчестве в 60-x - начале 70-х годов принимала большое участие Т. Никольская, которой и выражается глубокая признательность. Составитель благодарит также всех, кто оказал ему в свое время помоць.

Сиитаем нужным особо оговорить вопрос правописания, - ибо особенно в ранних стихотворениях Вагинова мы старались найти баланс межау своеобразной пунктуачией его и нормами современного русского Правописания (ИногАа знак препинания может разбить Иелостность образа). Исправленные ошибки в первоизданиях и малозначительные варианты нами спечиально не оговариваются.

п у т ш ш с т в и в x a o c (cc.

Перепечатывается с отдельного издания, вышедшего в издательстве "Кольчо позтов". Петербург, 1921. Здесь нами добавлены несколько впервые публикуемых стихотворений, относящихся к зтому ииклу, но не вошедших в издание повияимому из иензурных соображений. Ми здесо вдали (с. 37 ) печатается с уиелевшего корректурного оттиска. На палубах "Летучего голлакдиа" (с. 38), Умолккет ли (посвященное 8. Смиренскому, с. 39), Петербурхиа (с. 40), 3a осоху (с. 41) печатартся с рукописных автографов, относящихся к сборнику. Учитывается и рукопись части сборника.

Бегут тумана (с. 21) - в рукописи в последней строке первой строФы: "потухшие угли".

Bихро, бей (с. 24) - в рукописи первая строка: "рука, ударяй по лире".

n e t e p 6 y p r ckne hо 4 n (c.c. 42-75)

Печатается с рукописи неизданного сборника и отдельных автографов. 3десь отсутствуот тексты 18 стихотворений, копии которых нам получить не удалось. Ниже мы указываем и отдельные публикачии. Стихи, публикачии которых в периояической печати не отмечены, печатартя впервше.

Переверкул глаза (с.43) - рукописный вариант последней строки: "открыв тоскливнй и квадратный рот".

y милах ко2 (с.44), Ynaлa кочо (посв. 8. Пурье, с. 49), Покрал, прикрал (с. 50), Одик бреду (с. 53), Палеи мой сияет (с. 59) альманах "Звучашая раковина", Петрограя 1922.

C Aнтиохией (с. 45) - машинописный сборник "островитяне", вып. 1 , Петрограя, сентябрь $1921 \mathrm{r}$.

Cnum e рескииах (с. 48), B кагорках горках (c. 54), H умер ок (с. 56), Черкеет кочо (с. 60), Петербургский звездочет (c. 64) изданный типотрафски сборник "Островитяне" 1 , Петрограя, Аекабрь 1921.

Опято у окок (с. 51), Камия горит (с. 52) - сборник "Ушкуйники", Петрограя, 1922 .

$B$ перкатыx облаках (с. 63) и Помко последкро кочо (Dкоша, с. 68) впоследствии вклочались в сборники 1926 и 1931 r.., но печатартся 
здесь ввиду большего стилистического и смнслового соответствия. Первое публиковалось и в сборнике "Город", Петрограя, 1923. Санам Нева (с. 69) - печатается с рукописи. В "Пاетербургских ночах" был более пригодный аля чензуры вариант начала:

И Флаг крнлатым ИАОЛом взойдет

Аля Индии уснувшей, Аля Китая,

Для черных Стран, не верящих в восход.

Hеm, не любль закат (с. 70): "В казарме умирает человек" - имеетСя в вияу аруг аетства Сергей Крейтон, сын архитектора-англичанина Лю6ово опято томит (с. 55), Двенадиато долгих дкей (с. 57) - журнал "Записки передвитного театра П. Гайдебурова и Н.Ф. Скарской", Петрограя 1923 , 57.

Живу отиелоником (с.71) - там же, 1923. N 50.

Усталость в mеле (с. 72) - сборник "Абраксас", Петрограя, октябрь 1922.

мой бог гкилой (с. 73) - сборник "город", Петрограя 1923. Bпослеаствии вошло как стихотворение тептелкина в "Козлинуи песнь".

Стихотворения Один бреду (с. 53), Чернеет ночо (с. 60), Ломнх последноо ночо (с. 68) были перепечатаны в "Антологии петербургской nоззии", ed. by George Ivask and H.W. Tjalsma. München: W. Fink 1973, cс. 164-165).

С тихотворения 1920-30-x rr. (cc. 76-106)

Здесь собраны отдельные стихотворения, печатарщиеся впервые с рукописей и с разрозненных публикаций, не вошедших ни в один из авторских чиклов. Расположение приблизительно хронологическое, но указаны лишь точно зафиксированные Ааты.

Под рохов (с.77), Плавут в тарелке (с.78) - "островитяне" (нашинописний сборник) 1 , Петрограя, сентябрь 1921.

O, заверни в конфетнуо (с. 79) - "Островитяне", 1, Петрограя, аека6pb 1921 .

Cидит ока (с. 80) - "Ушкуйники", Петрограя 1922.

Бегу в ночи (с. 81) - "Абраксас", октябрь 1922.

Нскусство (с. 82) - "Абраксас", ноябрь 1922.

A снял canoz (c. 83) - альманах "Lех позтов", $* 3$, Петрограя, 1922 Я променял (с. 84) - "Альманах Петербургского объединения обновленното искусства", N 1 , Петроград 1922.

Немного меда (с. 85) - с рукописи. Вариант 5-6 строк:

Но вот они среди долин Урала,

вот они лежат в чепях и слышат треск домов.

Ночь отгорела (с. 87) - сборник "Город", Петротрая 1923.

Bu римскои дерхавной (с. 88) - из альбома А.А. Раяловой. Архив Пушкинского Дома.

3апись в альбоме б. Смиренского приведена в его неизданных мемуарах "Странствупщий знтузиаст". Обе напоминают стихотворные подписи М. Волошина к его акварелям. Ср. такме трехстишие А. Ахматовой "Простишь ли мне зти ноябрьские Ани" (1913).

Ma pохдека (с. 91): в одной из рукописей вариант конца третьей строки - "снежной" вместо "прежней".

He nестрох, но радостиой (с. 92) - "Записки передвижного театра", 1923. 57 .

До белих барханов (с. 93) - альманах "литературные вечера". Петроград 1923. вип. 1.

Он думал (с. 97) - с черновика цГАли приблизительно 1925 г. Вибран один из вариантов. 
Я стал просвещивающей формой (с. 98) - сборник "Костер", ЛенинrpaA 1927.

Стихотворения К роману "Козлиная песнь" (СС.99-103) - первое взято из печатного издания (Ленинграя 1928, с.48), остальнше из рукопи-

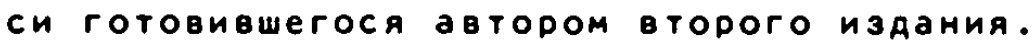

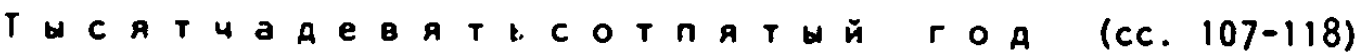

Печатается с рукописи. Первне 11 строк в виде отдельного стихотворения в "Oпнтах" объединены с аругим (Мрак побелел, с. 167), которое публиковалось в альманахе "Звезда" (1930).

О п т с о А А (cc. $119-175)$

Печатается с текста одноименного сборника (Ленинграя 1931) 3 a Искпочением Авух стихотворений, включенных в соответствии с авторским планом в "Петербургские ночи". Включены такме стихотворения Любово страшна (с. 122), 4 пестрой хизно моя била (с. 129), Под лихолетоем одичалам (с. 140) из сборника 1926 года и 2-я часть Пески слов (СС. 171-174) из мурнального варианта ("Звезда", Ленинграя 1927, N 8). Ниже отмечартся отяельные публикации и рукописные варианты.

Позма көадратов (с. 120) - "Абраксас", февраль 1923 r. В сборнике 1926 гояа Послеяняя Строка 3-ей части читается: "Великой Гречии роскошнше утра."

Лю6060 страшна (с. 122) - с6орник "Город", Петрограя 1923. Среди кочних (с. 123) - "Абраксас", октабрь 1922 r. 6ез ремарок: "पеловек", "Хор".

Шумит POдос (c. 124) - "Абраксас", ноябрь 1922 г. B "Oпнтах": 6ез послеАней строФы.

Я польбил (с. 125) - "Мизнь искусства". Петрограя 1922, 22.

$H$ neсmpoŭ (с. 129) - "Записки передвижного театра", $1923, \mathrm{~N} 57$. Hе человек (c. 130) - "Жизнь искусства", 1923, M 19. Аата Аана по сборнику 1926 . В "Oпнтах": ноябрь $1923 \mathrm{r}$. Одик средо мгла (с. 132) - в рукописи в последней строке: "гения и Сна".

Под гром войка (с. 133) - в "Опнтах": 6ез послеяней строФн.

o, coenaú (c. 138) - печатается с рукописи. Вариант в первой строке: "гремящей".

Нз хеновиднах слов (с. 139) - "Позты наших аней", Москва 1925. Отшелокики (сс. 143-145) - первая строка - вариачия известного начала І-й сиены 5 акта "Сна в летнор ночь" Шекспира, обнино перевоаившегося как "Лунатики, влобленные, Позты" и создавшето известнуо траяичих в русской поззии - Ср. "изгнанники, скитальцыи позты" (М. Волошин), "раклы, безумин и галахи" (Хлебников). Печатается с рукописното варианта с авторскими примечаниями. B письме, откуат Он взят, Имеется слеАуощий пост-скриптум: "Вот и все повествование о трех ипостасях, о состарившейся венере и о превратившемся в сатира, но сохранившем крылышки Эроте. И не такая же ли пустыня вокруг нас и не тот же ли столб возвшшается в ней." Bпервые под заглавием Позма в альманахе "Ковш", кн. 1, Ленинграя 1925.

He muисо (с. 148) - журнал "ленинграя", 1924, 23.

O, cxолоко леm (c. 149) - nepeneqaтано в сборнике "Ленинтраяские позтш", Ленинград, ГихЛ, 1934.

Bорон (с. 152), Н скова мке (с. 154) - "Ковш", Кн. 4, Москва-Ленинтран 1926 . 
Н скова мне (с, 154), Над миром (с. 155), В хниговращалищах (с. 162) - альманах "Собрание стихотворений", Ленинтрая 1926.

Тебе примерецился (с. 159), Мрах побелел (с. 166) - альманах "Звезаа", Ленинграя, Иза-во "Прибой", 1930.

Hочb (с. 161) - Сборник "31 рука", Ленинграя-Москва 1927, с.3. Здесь впервне печатается расширенний вариант со вставкой по рукописи (строки 21-28).

За ночор мочо (c. 163) - журнал "Звезда", 1928, F. Вариант С разночтениями - в книге: Л. Борисов, "Родители, наставники, позтн". Москва 1967, с. 87, 2-е издание 1972, с. 68.

Деа пестрих одеяла (с. 164) - по указанио А.И. Вагиновой посвящено М.M. Бахтину.

Эллияиста (с. 166), Om берегов ка берег (с. 168), Не лазоревий дохдо (с. 169) - альманах "Ларь", Ленинграя 1927.

Элликиста (с. 166), Дрохал проспехт (с. 170) - альманах "Костер", Ленинграя 1927.

Не лазоревай dохдо (с. 169) - мурнал "Звезда". 1927, " 3 с разночтениями.

Стихотворения Шумит Родос (с. 124), Под гром войни (с. 133), H снова мке мерещится (с. 154), Музика (В книговращалищах, с. 162) Эллияисти (Ма, эллияисти, с. 166) были перепечатаны в "Антологии петербургской поззии", München 1973, сс. 165-168.

3 в ук०пОАО 6 и е (cc. 176-208)

Цикл включает стихи 1929-34 rr. В альманахе "Aполлон-77" (Париж 1977) бнла помещена публикация большинства стихотворений зтого инкла (26 из 31) А. Мальмстеда И Г. Шмакова, К сомалению с многочисленными ошибками и опечатками. Здесь печатается с рукописи, с учетом нескольких публикаций.

Прехрасен мир (с. 193), обхеатели (в повашекном горе, с. 194), Oн разлюбил себя (с. 192) - альманах "Звезда", Ленинграв, иза-во "Прибой", 1930.

3a годом год (c. 200), Oтравок (Как халь, c. 199), Баллаda (3өyкоподобиe, с. 201) - журнал "Звезда", 1933, 1.

Подделки (с. 204), Вступил в Криму (с. 206), Промозглай Питер (с. 207) - "Литературннй современник", 1934, N11 пов заголовком "Посмертнне стихи".

Лекияград (Промозглай Питер, с. 207), Норд-ост (с. 205) - "День поззии", Ленинграя 1967 (публикачия Л. Черткова и Т. Никольской). B ady (c. 208) - Aругая датировка: Аека6рь 1933. 
ПОЭЗИЯ КОНСТАНТИНА ВАГИНОВА

Константин Константинович Вагенгейм родился в 1899 в Петербурге - точная дата неясна - По овним сведениям - 4 апреля, по аругим 21 сентября (Старого стиля). Во время войнн - 1915 гояу - eто отец (тогда военный) изменил свор немецкуо фамилию на вагинов. Семья отца издавна жила в Петербурге. Известно, ито один из Вагенгеймов врач - лечил Пушкина и В. Одоевского. Мать позта происходила из сибирской семьи. Учился он с 1908 года в гимназии Гуревича, которуб окониил в мае 1917 года. 8 детстве - в 1913 году - Barинов путешествовал по Каспийскому и Черному морам, по Кавказу. 8 августе 1917 года он поступил на орияический Факультет Петроградского университета и иислился там до осени 1921 года, причем посещал и лекиии историкофилологического факультета. Однако Фактически он уиился там мало, так как в 1918 году бшл призван в Краснуо Армию, откуда демобилизовался лишь в апреле 1922 года. Служил он на польском Фронте, за Уралом, а такме в Петрограде (в последнее время - военним пи(арем). B 1923 году Он поступил в Институт ИсториИ Искусств (Основаннай и еще руководимнй графом 8.П. Зубовнм), Собравший в зти годы наиболее блестящую профессуру, и уиился там до 1926 гоАа. ЗАесь он преимущественно занимался на словесном отделении (гае межау прочим изучал латынь), а такме на высших курсах искусствоведения. 1 вся алльнейшая жизнь Вагинова протекала в Петрограде, откуаз Он внезшал лишь несколько раз для лечения (в Медвежьегорск, на Украину, в Сухуми и ялту). 25 апреля 1934 года 8 агинов умер и бал похоронен на Смоленском кладбище близ т.н. Блоковской AOPOMKи .

Как он Сам написал в одной из неопубликованных биографий - "в гимназические годн увлекался Шекспиром, потом Гиббоном И Бодлером, ПОА влиянием которого стал писать" в 1916 году. К зтим именам следует присоединить также Овияия, Эагара По, Уолтера Патера, a такmе де Квинси, чья книга в русском переводе имелась в отиов1 Сведения из архива Ленинтрадской области, Ленинградского архива литературы и искусства, Пушкинского Аома, Музея Изобразительнuх Искусств в Москве (материалы к неизданному второму тому "Писателей современной эпохи") и AD. 
ской библиотеке. ${ }^{2}$ С Аетства Вагинов увлекался нумизматикой, археологией, что было связано с его интересом к античности.

Ранние стихи вагинова, записанные, по словам знавших его, в парчовой тетраяи, не сохранились. Таким образом творчество его известно лишь начиная со стихов 1919 года в сборнике "Путешествие в хаос" (Петербург 1921). ОАнако первой ето публикаиией были стихи в машинописном сборнике "Островитяне" (Петрограя, сентябрь 1921), вышедшем чуть раньше в том же году. И уже в зтих первых опубликованных стихах Вагинов, невзирая на известнуо аморфность И анемичность Форми (отчасти несомненно намереннуо), Аостаточно полно внявил свое позтическое своеобразие и индивидуальное вияение мира. Первой литературной группой, К которой он принаялемал и которая издала зтот сборник, было близкое по характеру к згоФутуристам "Аббатство raзров" ("Кольцо позтов"), куаа кроме нето входили "приоры" Б. Смиренский, Б. Смиренский (Анарей Скорбннй), С. Нельяихен ${ }^{3}$, драматург К. Маньковский и худотник Н. Мандаров (автор обложки к "Путешествио в хаос"). Группа не имела ни программы, ни устава и просуществовала недолго. Сам ватинов считал свой первнй сборник неудачным (существуот исправленные им зкземплярш, нам оказавшиеся недоступными) и впоследствии скупал его. Гораздо более вамным, чем участие в зтом богемном объединении, представляотя параллельные занятия вагинова в "Доме искусств" в стуаии Н.С. Гумилева, ставившего, как известно, во главу угла T.н. "науку о поззии", но вместе с тем свободного в своих оценках, да и в стихах, от слепого следования своим теориям. Участиики студии образовали кружок "Звучащая раковина", продолмавший собираться еще некоторое время после гибели своето мзтра, все участники которого (кроме Вагинова) однако так и не вншли за рамки "цеховой" академической позтики. Летом 1921 года Bатинов был даме принят в ранге "подмастерья" во второй "Lех позтов" и оАновремен-

2 "исповеяь англичанина, употреблявшего опиум". С-Петербург 1834. в этом издании приписана Ч. Маторену, автору "Мельмота - скитальиа". Э. Гиббон - автор "Истории упаяка и разрушения Римской империи".

3 См. о нем нашу с T. Никольской публикаиио в NRL (Almanach "Neue Russische Literatur") Salzburg 1978, с. 99-100: "Стихи Cергея НельAихена". 
но в Петроградский Совз поэтов, такме руководившийся Гумилевым, - mожно предполатать - по инициативе ero и Apyroro "mactepa" 0. Мандельштама, со вниманием относившегося к твориеству ватинова. Ибо с "млаяшими" (Г. Адамович, Г. Иванов, Н. Оиуп) отношения у ватинова не сложились. Уже в 1922 году он посвящает им несколько язвительных строк своей прозы в альманахе "Абраксас", а те в свов очередь исклочарт его стихотворение из переизданного в 1923 году в Берлине альманаха "Чех поэтов". Не касаясь тех или иных личных или общественных аспектов зтих отношений, укажем, что и Форма и существо поззии вагинова не могли не остаться чуманми неоклассикам нового "Чеха". Интересно однако сопоставить здесь несколько высказываний о ватинове наиболее объективного представителя зтой группе - . Адамовича.

B петроградской газете "Жизнь искусства" от 16 января 1923 гоАа Адамович писал: "К. Вагинов - прямая противоположность ему [Тихонову]. В старину про него сказали бы - Божьей милостьо. Он весь пронизан музыкой. Если вагинов глубже и шире вздохнет, если он будет больше думать и настойчивее хотеть, если он перестанет кокетничать своей неврастенией - он будет позтом. Ему надо долго учиться. Hо в руках его не труба и не барабан, а настоящая скрипка." в том же тоду (1923) в парижском журнале "Звено" в 182 от 10 сентября он сопоставил поэзио Вагинова с живописью художника-символиста M. Чурлиониса и сослался на известных ему лодей, полагаюиих, что в стихах Bатинова заложена новая позтика. Здесь же он вспоминает, что "Гумилев относился к нему дружельбно-насмешливо, но выделял." В "Звене" же от 24 января 1926 года в N 156 он указывает на близость вагинова к поззии сорреализма (в частности Поля Элюара), вспоминает в связи с Ватиновым стихотворение Лермонтова "По небу полуночи". В "Звене" от 1 августа 1927 N 2 отмечает: "резко своеобразен Вагинов, беспутный, бестолковнй, сомнамбулический позт, которому еАва ли суждено оставить какой-либо след в русском искусстве, кроме бархатных виолончельних звуков, кроме удивительной певучести, зтого "дара не6a". И наконец в некрологе "Памяти Bагинова"4, воспоминая о занятиях в студии Дома искусств: "Стихи читали подряд - как сидели. Гумилев блатодушно одобрял, вежливо и высокомерно порииал, если

4 Газета "Последние новости", Париж, 14 июня 1934 Г. М 4830. 
замечал какое-либо отступление от внушаемых им приниипов. Стихи вагинова вызывали в нем сдержанное, бессильное раздрамение. они поистине были "ни на что не похожи": никакой логики, никакого смысла; образы самые нелепне, синтаксис самый Фантастический... Инота хотелось рассмеяться, махнуть рукой. Но за чепухой ватиновского текста жила и звенела какая-то мелодия, о которой момно было повторить, что "ей без волненья внимать невозможно". Гумилев зто чувствовал. Он понимал, ито у других его учеников, только что продекламировавших стихи гладкие и безупречные, нет именно того, что есть у вагинова. Ero сераило, что он не может убеяить вагинова писать иначе... А тот улыбался, соглашался, смущался, - И на следуощий Аень приносил новое стихотворение еще "безумнее" прежних, но еше музыкальнее."

ПрисоеАиним сода И осторожнуо оценку H. Oиупа из его статьи "о поззии и позтах в СССР"5, "Кз поэтов, вскормленных револоцией, мы ... знали вагинова, тогаа еще мальчика декадента с остротой и своеобразием, если и не развившимися с тех пор, то все же, судя по нескольким недавним стихотворениям - И не утраченными". Нам передавали и устный отзыв Гумилева о "Путешествии в хаос", смысл которого сводился к тому, что "несмотря на жеманство и надуманность зто начало большого позта". Большего трудно было конечно омияать от представителей акмеизма, с которым поззия вагинова сближалась лишь изредка. Ни один из гумилевских приниипов поззии (кроме разве Фонетического) не выдерман у него до кониа. Хорошо вначале относился к нему Мандельштам, но чем лучше писал вагинов, тем более он к нему охладевал. Отчужденно относилась к нему и Ахматова. И сам Вагинов и Аругие сиитали его в зтот период символистом ("я смиволистом свесился во мглу", с. 149). Однако ни о каких литературных контактах с представителями зтой школы нам неизвестно. B некоторых ето письмах чувствуется пизтет перед Анареем Белым, "Петербург" которого без сомнения оказал влияние на его роман "Козлиная песнь" (1928). Есть свидетельство, что из русской прозы вагинов хорошо знал лишь символистскуо. По словам А.Е. Максимова интересовался он и вячеславом Ивановым.

5 журнал "числа" 7-8, Париж 1933 
Как 6ы то ни 6ыло, среди позтических группировок, в которых он принимал участие в свои ранние годы, следует виделить группу "Островитяне". 06разовалась она в 1921 году и просуществовала Ао 1923 года, хотя Аружеские связи межАу членами ее сохранялись и позднее. Сода входили кроме Вагинова Николай Тихонов, Сергей Колбасьев (более проявившийся как прозаик) и Петр Волков - все Позты, хотя и с различной, но несомненной инаивидуальностьо. Параллельно ватинов участвовал в альманахах "Абраксас"(1922/23), "ГороА"(1923), "Ушкуйники"(1922) и Ар. Но уже в 1922 гоАу он писал в частном письме: "я проходил через өсе позтические кружки и организачии; теперь мне зто давно не надо... Я хочу работать один." Однако попштки ето издать второй более зрелый позтический сборник "Петербургские ночи" - в Госизате, или в издательстве "Круг" - остаотся безуспешными. Он писал своей корреспондентке в Берлин еще в 1924 rоду, что надеется на вuход зтой книти, над которой работал два года. "В ней отражается Петербург, не современний, а наяедсь, И вечний, его одинокая борьба и жизнь одного из его жителей. Почти осе стихи отдельно били напечатаны в разных мурналах. В офичиальных органах я почти не участвур, считая, что зто было бы недобросовестным с моей стороны, так Как я резко расхомусь с современностьо." 8 Aругом письме он називает зтот сборник - "книга романтическая и Фантастическая".

Лишь в 1926 rоду выходит его вторая книга стихов (без названия, посвяненная его жене - А.И. Федоровой), знаменующая новый зтап в его позтическом творчестве. Hо стихи, написанные в совершенно новой манере, начинахт появляться у него уме в 1922 году ("Среди ночншх блистательных 6лумданий", С.123, "Бегу в ночи ная Финскор Aорогой", с. 81). Тогда же он писал своей корреспондентке: "весной мне стало ясно, что я не должен писать дальше, как я писал. я дошел до грани и дальше уже была бы подделка под самого себя." Этим и обвясняется то, что некоторые из своих ранних стихов он воследствии с легкостьо "раздает" разным персонамам своих иронических романов в том иисле - внутренне не близким.

Hо поиведем ене серио отзивов о его стихах раннего периода, соnеотамие злементы анализа его поззии. вначале свидетельство участницн "Звучаней раковины" верн лурье в ее статье "Петроградское"

6 rasera "Ани", Берлин, 5 aвгуста 1923 roaа, N232, с. 12. 
"Стихи Barинов пишет почти ежедневно, обнчно чиклами... Он символист, клоч к пониманио свонх стихов часто находит лишь после их написания: тога вокруг одного основного стихотворения создает целый стихотворный иикл, причем последние стихи его ииклов быварт обынно проясненнее первых; таким образом у вагинова в творческом прочессе - два периода: первый, когаa он пишет непонятное, затем второй, когяа от непонятного переходит к проясненним произведениям... У него крайне забавная манера писать: строчки он нанизывает, подбирая слова по зөуковой близости или приятности красок. Произведения его насыщены крайне неожияанными образами, часто в них сквозит что-то романсовое. Barннов почти не пользуется чистой рифмовкой, считая ее чересчур законченной и резкой, а предпочитает ассонансные окончания. Такме он избетает однородного метра и в особенности лобит смешивать разностопные ямбы." Правда, в письме к автору зтого отзыва вагинов говорил: "Последние nолтора года м4 не писали аруг другy и прочитав Bawy статьо я увияел, что мы утратили прежнор связь и понимание" и ниже: "Tа пора иветных книмек и путь от слов к мысли давно прошли и потому мне странным показалось, что Вы так пишете обо мне, ведь тот я давно умер." Это однако не умаляет отзнва.

Позтесса Наяежда Павлович, говоря о группе "Островитяне", пишет: "Наиболее Ааровитий из них Константин Вагинов. Это Подлинный сын Петербурга, классического Петербурга и умирариего. Как колонны Aлександровского ампира хочет прямиться стих его... Но гнилая трясина колишется под Петровим городом и она же поит и питает стих Barинова. Ero боr - Aполлон, но не тот лучезарный, осенивший античность, его Aполлон гнилой, с узкой груаьо, сухой и жестокий, и все же бог, И Под развинченностьо Авижений, Под Аряблой Кожей варуг иногаa просквозит извечная прелесть и задыхариийся стих выпрямляется и звучит ясно и торжественно." 7 Читируем дальше:

"K. Barинов весь в себе. Oн даме "nеревернул rлasa и осмотрелся", осмотрел себя внутри. Ero стих дериится на звтонических приемax. Cлова сочетартся Aруг с Aругом не no слоговой, a no 3 вуко-

7 "письмо из Петербурга. Петербургские позты". - мурнал "Гостинииа аля путешествуриих в прекрасном". 1, Москва, ноябрь 1922, с. 31. 
вой ассоциачии: крутись - карусель - семя, градом - огород, Монтекристо - скрипка и т.A. Позтому слова у него часто остраняотся, теряют обычное значение и сочетание их часто выпирает из обычных логических схем. 18

Валерий Бросов, речензируя сборник "Островитяне", писал: "еяинСтвенное, Что роднит их межау собой - зто попЫтка выбиться из шаблона зпитонов символизма. К. Baгинов подходит к зтой задаче немного через Футуризм, беря у Футуристов преимущественно приемы образа. отдельные строки е стихах Barинова интересны, но образы между собой не согласованы и стих, несмотря на нарочитые аллитерачии, тускли незвучен." 9

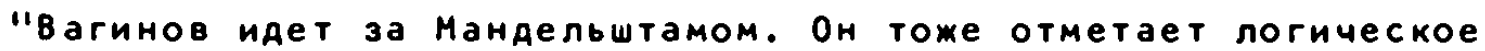
Авижение стиха, заменяя его фонетическим... Вагинов тоже пытается управлять большими звуковыми массами, строить бессмысленное, но стройное Фонетическое здание. Аля зтого надо быть Мандельштамом. Вагинов же, сиепляя стихи, довольствуется простыми звуковыми ассоциациями ("в нагорных горнах...", с.54). Тем не менее в каждой строке вагинова чувствуется сырая, еще не нашедшая себя, но подлинная позтическая острота."10

"Интересен Baгинов. Стихи его бред конечно, но какой заставлярщий слушать бред! Хорошей болезньо өстряхнуло вагинова - он потерял чувство обычного пространства и обниного віремени. Широко раскрытыми глазами смотрит на райские леса, которыми зарастарт городские площади и в трамвайном лязганьи слышит колокольчики коyевого Батдада. Лorические несообразности Barинов часто оправдывает верностьо своето звукового рисунка - редкий пример фонетического воображения. На этом построена Аикая книжка "Путешествие в хаос", книмка очень оная, плохого вкуса, но живая несомненно... Мне думается, весь Вагинов - зто рассказывание снов,

8 Аавия Выгодский, рец. на сб. "Островитяне". - газета "Хизнь искусства", 23 ивня 1922 г., 20, с. 4.

9 турнал."Печать и револочия", Носква 1922.6. сс. 292-293.

10 Лев Луни, "Новше позты". - литературная газета "Ирида" под реа. A.r. Фомина, 1922, неиза. - Архив Пушкинского Дома. Фона 568, оп. 1, еA. 125, CC. 221-222. 
прекрасных и тарщих неуловимо. Ero нередко бескрылие слова - тревожная неАОсказанность."11

"Константин Ватинов - совсем молодое имя, вннесенное на берет невской бурей последних лет. Ничего нет в нем от "стройного Петербурга"l - зто ночной rолос, тревожный и горький. Первая книга "Путешествие в хаос" - еще млаяенчески беспомощная, лишенная комПозичионных заяаний, Построенная Исклочительно на звуковом ощущении отдельних слов, но уже исполненная пророчественного бреда. Вторая - ене не изданная "Петербургские ночи" - аань глубоко волнуощей любви к родному городу, ставшему ГОродом вечности. EГO Петербург - в аинамике, в неведомом плаваньи. Сквозы ватинова протекает ритмическое ощушение давних и близких культур, но не в остром осознании их творческой воплощенности, а совершенно так же, как в зрачках слепого отражается мудрий узор созвездий. Вагиhов cлen. Emy анно слишать поров cлабо, поров очень неуверенно, но все-таки слишать. Я аумар, что он ничему не смотет научить, да у него и не надо уииться. Ауша его давно переросла тело и меwaer emy ходить nо земле. Вот почему зти оношеские стихи, волнуот такой ветровой шириной и неуотом."12 "у него есть подкупариая лиричность. В стихотворении "У милых ног венецианских статуй" (с. 44) он еще усиливает ее приемом лирического повторения (которим так хорошо пользуется, мемау прочим, Сергей Есенин, например: "Трубит, трубит погибельншй por... как ме бить теперь нам?.."). B Aругих стихотворениях Вагинова лиричность заглушается метафорической образностьо, несколько отвлеченной, отдарией холодком малопонятной абстракчии."113

11 8. Р[омдественский], рец. на сб. "Путешествие в хаос". - журнал "Книга и револоция", Москва-Петрограя 1922, 7(19), c. 64.

12 он же, "Петербургская школа молодой русской поззии". - журнал "Записки передвижного театра им. П. Гайдебурова и Н.Ф. Скарской", Петрограя, 7 октября 1923 г., 62, сс. 2-3.

13 Илья Груздев, реч. на альманах "Звучащая раковина". - журнал "Книта и револоиия", 1922, 7(19), с. 60. 
"Очень сложно и выдержанно пишет Константин Baгинов. B нем словно воскресает символизм, но как-то совсем по новому, проведенный через XVIII век и богато обогащенний им."14

"K. Вагинов подобно Н. Тихонову - позт с уме намеченными путями. Ero зкзотическая метафора всегаa свежа, в своей боязни истертого и дешевого он не боится показаться смешным и иасто впадает в неловкости - истинный путь завоевания. Интересно отметить влияние Франиузских символистов, гораздо в большей степени, чем позтов, близких ему по времени и по языку. Недавно вышла книжка Barинова "Путешествие в хаос", показавшая капризное своеобразие и неподаельный зкзотизм темы. Аля двух-трех по настоящему хороших стихотворений этой книги стоит преодолеть баррикады дешевых зФФектов и метаФор сомнительной иенности. Ватинов в своих ошибках самостоятелен, а зто уже нечто."15

"у Константина Baгинова в стихах - раздумчивая созерцательность восточного характера. Ero мысли смутны и неотчетливы, но он умеет завораживать тяжелым течением словесной массы. в причудливых извивах его стиха много своих слов, есть музыка."16

И в заклочение - отзыв Bладислава Ходасевича: "Стихи, которые вагинов иитал в кружке "Звучащая раковина" и на "Hаппельбаумовских понедельниках" были довольно несуразны, до последней степени метафоричны и до смысла в них трудно было добраться. Но в самой несвязице ватиновских стихов было что-то свое, она была как-то своеобразно окрашена. Наконец звучала в них подлинная ритмичность, они были к тому же хорошо инструментованы. Словом казалось, ито из него выйдет толк. Так смотрели многие, в том числе Гумилев."17

14 он же, "русская поззия в 1918-23 rr." - там же, 1923, $3(27)$, c. $37-38$.

15 я.торн, рец. на альманах "Ушкуйники", 1922 . Архив їушкинского मома. Ф. 98 , еА. 133, сс. $2-3$.

16 Aвгуста Рашковская, "Поззия 'молодых" - - газета "хизньискусства", 1923, 27.

17 Парижский альбом, II. - газета "дни", Париж, 13 апреля 1926. 
Korá Barинов умер, Ходасевич тепло отозвался о нем в очередном обзоре в raзeте "ВозрожАение", но саержанного отношения К его поззии не изменил. отметим, что и вагинов холодно отзнвался о ero cruxax.

Позтический путь Вагинова можно приблизительно разбить на четыре периода. Первий - символистско-романтический - 1919-23 rг., достаточно полно освещенний в Аанной подборке критических высказываний и к которому мы еще вернемся в суммарной оценке.

второй период - 1922-25 rг. - особенно значителен аля его творчества и именно он обеспечил вагинову особое место в русской поззии. Он в основном охватнвается его второй книтой стихов 1926 гоАа и замыкается впервые публикуемой здесь Араматической позмой "1925 rOA" (CC. 107-118).

Вот что писала участница "Звучащей раковины" И. Наппельбаум в Париж позтессе Н. Берберовой: "Костя Вагинов много пишет, много работает, много учится и иитает, главным образом старуо Франиузскуо литературу. Книжка его внзвала много толков, она взбудоражила всо литературнур публику. Только теперь они заметили, что зто "крупное явление" в русской литературной жизни и затоворили о том, что надо что-то делать, чтобы ее выделить, чтобы побольше внимания вообще оказать вагиновскому творчеству. Чтобы издать зту книжку, материально сложились почти все литераторн Ленинградо и теперь гораятся ер. В Сорзе Писателей был устроен вечер с приветственними речами, с докладом и т. mе доклая о книмке." 18 Большуо роль в зтом издании сыграл писат тель М. Фроман, что явствует из автографа на одном из зкземпляров: "Дорогой Михаил Александрович! Эта книжка до некоторой степени Ваше яитя. Детский Дом [типография имени Ивана Федорова] одел, не без Ваших настойчивых указаний, ее в скромное платье. Вам Ааме снились сни по поводу еe первого выхода из मетдома. Примите ее от меня, как знак лобви и Аружбн. В.8.III.1926 г." Что же касается вечера в Conse писателей, то отчетов о нем найти не удалось, но некоторнми воспоминаниями с нами поделился покойншй М.М. Бахтин. Он в частности указал, что вечер открылся вступительным словом Бенедикта Лившица, сравнившего Barинова с Анахарсисом, а с основ-

18 н. Берберова, "из петербургских воспоминаний". - журнал "опнты" HoD-AOpK 1953.1, c. 116. 
ным Аокладом выступил Л.В. Пумпянский. Основной тон выступлений был положительный, но были и нападки со стороны крестьянского позта Ивана Приблудного. Можно предположить, что вагинов был не очень доволен докладом, результатом чего оказался последуощий конфликт с Пумпянским, которого Baгинов вывел в образе Тептелкина романе "Козлиная песне". Пумпянский же текст доклаяа уничтожил. А известный нам уиелевший Фрагмент его не дает материала для суждений, кроме разве того, что доклад был вндержан в соииологическом нльче, что и могло вызвать раздражение позта.

В "Красной вечерней газете" от 21 ноября 1926 года была помешена речензия на книмку за подписьо О.K. (возмомно постоянно сотруаничавший здесь Иннокентий Оксенов). Там говорилось: "вагинов пока что поэт для позтов и критиков и его стихи с тратической тематикой, живущие деформированним классическим каноном, еще не могут найти дороги к широкому читатело." Автор надеется, что Barинов еще приблизится к современности и "из пережившето становление символиста" превратится в живого волнуощего позта. Мастерство 8атиновым уже завоевано. Будем ждать "оживления статуи". Слова о "классическом каноне" взяты из доклада Пумпянского.

Мир Ватинова зтих лет - мир античных ассочиачий, перенесенных на современность. Но зто не торжественный мир Зллаян Вяч. Иванова, М. Волошина, 0. Мандельштама. Это болезненный деградирующий и тем ярче чветущий перед падением зллинизм упадка. При всей своей ущербности Он ОАнако сроден "Зллинской религии страдарщего Бога" Вяч. Иванова. Вагинов провидит вечные архетипы сқвозь неказистые и гротескные черты современной ему действительности. Даже обынные счены городской жизни (свадьба, прогулки, вечеринки) приобретарт под его пером значительность Аревних мистерий. Сквозь реальнуо reографио Петрограда (Сенная, Стрелка, Гостиный Авор) Oн вияит Антиохио, Александрио, Родос - в достаточной мере условнuе. Aа и Петербург его, только начинариий оправляться после разрухи, близок к известному пророчеству, что ему "быть пусту". Евангельские образы первого периода (Иисус, Мария, Иордан) сменявтся образами 0рфея, Филомелы, Психеи, именами античных божеств. Вера в Христа подорвана и отвергнутые христианством древние боги возвращартя в мир, приобретя за өремя своего изгнания оттенок демонизма. Aполлон из прозаического "Монастыря господа нашего Anoлnoна", требуриий человеческих жертв, "ужасная венера" (с.116) пьесы 
"1925 гоя", тяе наиболее рельефно предстает авторская позииия. Среяи смешения времен, верований и культур, порожденного револоционным Хаосом, растерянно бродит авторский Авойник Филострат, имеющий отдаленное сходство с зллином Филостратом, автором Книги описаний "Картины" и романа об античном чудотворие Аполлонии Тианском. 81926 году 6лизкая Barинову позтесса $\$$. Hanneльбаум сообщала своей корреспондентке в Берлин, что он написал пьесу "разумеется, не постановочнур". Филострату здесь противопоставлен собирательный тип интеллигента-конформиста тептелкина, отличариийся ОАнако от свое го однофамильча из "Козлиной песни" упрощенностьо расСужАений. Считается, Что прототипом ему зАесь послужил критик $\Pi$. Медведев. Тептелкин очевияно раздрамает Филострата, но он не врат ему, отношения их напоминарт отношения Санчо Пансы И Дон Кихота. Это становится особенно очевидным, когаа благодушные разглатольствования зтого полупопутиика, полусменовеховиа сменяотся месткой речьо Начальника чеха, явно представлявщето "подлинно пролетарскуо" рапповскуо критику. Воздух зпохи делается все бoлеe разреженным. Тема последних носителей культуры, уаллившихся от сложности и жестокости жизни в замок, полнее развернута в упомянутом "Монастыре господа нашего Anonлoнa" (альманах "A6раксас", 1922) и в "Козлиной песне", а такме имеет общие черты с позмой С. Нельяихена "Праздник". B пьесе имеотся явные реминисченции из пушкинских "Пира во время чумш" и "разговора книгопродавиа с позтом" - впервне обнамается связь с русской позтической траяицией.

Orход Barинова оr зстетских кружков связан у нето с поиском новых выразительных средств, нового взгляда на мир в среде представителей авантараистских групп, среди которых он впрочем, как и ранее, остается "аутсайдером". Так в 1923-25 rr. он сблимается с ленинградскими имажинистами - Вольфом Эрлихом и Григорием шмерельсоном. С аругой стороны занятия в Институте Истории Искусств сближарт его с мзтрами и адептами Формальных теорий литературы (М. Бахтин, Б. Энгельгарат, Б. Эйхенбаум, Б. Бухштаб), оказавших известное влияние на его твориество. Это ощушается в его третьей самой известной книге стихов (начиная с названия "Опнтн соеяинения слов посредством ритма", вышедшей в 1931 rоду',, так и в ро-

19 По нашим сведениям анонимное преяисловие к ней написано В. Саянов世M. 
мане "Труды и Ани Свистонова" (1929). Наиболее интересен однако его альянс с группой позтов "Обэриу", несколько младших его по возрасту. Зтот периоя поисков был связан и с последовательным ero участием в готовившихся, но так и не вышедших альманахах "Левое объединение" (1923), "Необычайные свидания друзей" (1925, имажинистский), "Ванна Архимеда" (1930 - обзриуты и Формалисты). Barинов выступал на обзриутских вечерах, в том иисле на известhом вечере 24 января 1928 года в Доме литераторов на Фонтанке, где читал стихи в сопровождении таниуощей балерины (он сам иронически описал зтот вечер в первой главе "Трудов И Аней Свистонова"'). Как вспоминали участники зтих выступлений, стихи вагинова лучше Аругих принимались публикой, так как казались более понятными. 81926 году был воссоздан "Совз позтов" и Barинов вместе с "обзриутами" и имажинистами публиковался в его изданиях "Собрание стихотворений" и "Костер". Этот третий "обзриутско-формалистический" период наиболее близок к его язвительной прозе и охватывает приблизительно 1926-30 rr. Период зтот нанболее сложен. Пройяя через отрицание новой действительности, отразившееся в оппозиционном аухе ряда его стихотворений ("Сынам Невы", С. 69. "я стал просвечиварией Формой", с. 98 и Ар.), он попытался все же Искренне понять ее, не меняя своей позтической системы, вклочить ее в поле своей вневременной созериательности (стихи 1924 года "O, сколько лет", с. 149, "Аа, чельй гоя", с.150). Но он увияел, что зто невозможно. И тогда начался кризисный период мучительной ломки не только найденной было гармонии, но и вкуса, период сарказма и гримас - менее литературно совершенный, но очевидно внутренне необходимый. Перестройка формальная шла параллельно с перестройкой общественной. 8 стихи зтих лет проникает ставшая традииионно русской тема Достоевского - "бездна вверху, бездна внизу". Ирония Вагинова, более проявившаяя, правяа, в его прозе- болезненна. Он - уасть осмеиваемого им мира, который он никак не может совместить с зовущей, но пугавщей его действительностьо. И алогизм его образов иной, чем у обзриутов - у тех он вырастает из отказа от траяиционной культуры и сомнения в новой, - вагинов же остается лишь в кругу сомнений и у него сохраняется присущая ему с самого начала странная логика, парадоксально существуршая на грани смысла ("Фонари, стоящие, как слези" и пр.). Некоторне сти- 
хи этих лет напоминарт Заболоцкого (параллели с которым проявятся $и$ в последнем иикле "Звукоподобие") сочетанием гротескного содержания с выработанностьо формн. Кстати иллострачией их отношений может служить Факт рекомендации Вагиновым стихотворения послеането "Футбол" 20 , которое он назвал "золотым самородком". 21 Кстати отметим, что близкий обзриутам писатель Г. Гор вспоминал, что Вагинов поздравил его с вышедшей в 1933 году авангараистской книжкой "Живопись".

Чтобы лучше понять этот его период, необходимо хотя бы коротко сказать о его прозе. В отличие от большинства позтов, иья проза обынно имеет много общего с их стихами, проза вагинова, за исключением самых ранних вещей ("Монастырь господа нашето Aполлона", 1922, "Звезда ВиФлеема", 1922, и начало "Козлиной песни", 1928), составляет совсем особуо стихио. Вагинов-поэт и вагинов-прозаик - зто доктор Ажекиль и мистер Хайд из известного рассказа Р. Стивенсона. Поззия его возвышенна, проза же, хотя и интересна, но как-то изначально безблагодатна. Если оговоренные вещи еще могут служить отчасти сниженным авторским комментарием К его стиХам, то из последуощих произведений ("Труан И ани Свистонова", 1929, "бамбочада", 1931, и неопубликованная "Гарпагониаяа", 1932-34) словно выкачан воздух, и то злая, то беспредметная ирония и перегруженная зрудичией литературная игра все чаще сменяотся мрачным безучастным констатированием аействительности, своего рода "неопередвижничеством". (Записи "городского Фольклора" и Фактн, полные "черного омора", почти без изменений перекочевываот из его записной книжки в романы.) (уществование же такого позта как вагинов в эпоху коллективизации и пятилеток парадоксально И объаснимо лишь Известной отстраненностьр бывшей имперской столицы от происходившего в стране. Феномен вагинова момет быть Понят лишь в связи С той рафинированной культурой, которая существовала в Ленинграде 20-x - начала 30-x годов. Если бы его, как писателя группы "Серапионовых братьев", спросили - с кем он, он ответил 6ы - с Филостратом. Однако он не мог аолго оставатьса на зтой позичии. Проза его, насквозь пропитанная ушедшей от нас злободневностьо, изобилуощая намеками и карикатурами, не лишенная

20 Напечатан в ленинградском журнале "Звезда", 10 за $1927 \mathrm{r}$. 21 В. Завалишин, "Николай Заболоцкий". - "Новый журнал" Р 58. H०D-मорк 1959, с. 123. 
интеллигентского мазохизма, была своего рода платой 3 a nраво сохранить нетронутым свой позтический мир. B начале 30-х годов над ленинградской литературой сгушартся тучи - исключартся из Сорза писателей и репрессируотся Хармс и Введенский, некоторые Аругие писатели. Вагинову же на зтом фоне предлагается в 1932 году принять участие в творческой аискуссии о прозе (нечто вроде самоотчета). Он участвует в сборе материалов по истории Нарвской заставы для сборника "Четнре поколения" (1933), ведет кружок заводских писателей. Нельзя сказать, ито зто проходит бесследно аля его прозы. Hо для поззии оказывается ненужным. Такая ситуаиия была общей Аля многих писателей а 30-е годы. Но Вагинов - один из немногих выбрал путь созериания, олимпийства - не надо забывать, что такое олимпийство тогаа требовало чисто олимпийской выдержки.

Речь идет о поззии его последних лет - 1931-34 rг., о периоде, который мы можем назвать "синтетическим". Bсе темное, мрачное словно оседает в его прозе ("Гарпатониада", рассказ "Конец первой любви", 1931) в то время как поззия достигает поразительной ясности, напряженности и чистоты. Вся сложность его мироощущения - человека XX века, наследника мировых культур - словно освобожАается заесь от строительных лесов и находит своето рода "золотое сечение". Bместе с тем стихам этим присуше некоторое метафизическое беспокойство, тревожная недосказанность, глубоко задевариий лиризм, - что спасает их от застылости неоклассицизма. Смертельная болезнь, жизнь между санаториями и больницами как бы ставят его над жизньо, заставляот смотреть на нее мудро и примиренно ("Почувствовал он 6оль", С. 202 ). Hanисанmое, наступя "на горло собственной песне", "Украшение берегов" (с.106) является единственным Известным нам исклочением.

В позтическом мире Вагинова есть общее с мироощушением иерар де Нерваля, Кольриджа, Эагара По, литературой Франиузского символизма, вызванное очевидно сходным Аушевным опнтом. Ранним его стихам присуца легкая взаимозаменяемость слов - смутный поток ассоциачий делает зто возможным. Границы между отдельными стихами подчас размыты - зто то "парные" стихи (как иногаa у мандельштама), то фратменты какого-то туманного зпоса с кочуощими образами и темами. Часто он сознательно разрывает логические связи, заменяя их ассоииатвными, - как правило, очень сломными. Рифмы его обынно приблизительны, нередко он сознательно отказывается от легкой рифмы, 
чтобы разбить стереотип. Hапример, рифма к "Ориген" - "плач" вместо напрашиварщегося "плен". Строки у него камутся подчас словно рассыпанными и перепутанными наборщиком (вообще его манера писать как бы отлитыми строками - от "Цеха поэтов"), - в порядке их есть нарочитая случайность, бессистемность. И сквозь этот хаос не всегда удается разгляеть черты сложного миросозерцания Вагинова, - но например в маленькой поэме "Петербургский звездочет" (сс. 64-65), как в катренах Нострадамуса, в спутанном виде предстарт Причудливо смешанными образы прошлого, настояще буаущето - именно "пророческий бред" по определенир В. Рождественского. Наплыв странных образов навояил иных критиков на мысль, что логические связи у него определяотся звуковым рисунком. Но это сужаение неточно - При всем ето вниманиИ к Фонетической стороне стиха, в ней проявляется особое интуитивное постижение мира, свойственное ему. Походя отметим, что среди ранних стихов попадаотся и реалистические почти протокольные зарисовки - "Помно последнор ночь" (с. 68), "Нет, не любло закат" (с.70). К его стихам, более, чем к чьим-либо приложимо определение Бальмонта - "поэзия как волшебство". Подобно Лотреамону и сорреалистам, он легко соединяет отдаленные понятия - "ветвистые дома", "женовидные слова" и в образах его живут поити несовместимые сближения - "безбрежное вино", "среди дворцов змеистых". Попадартся у нето и неологизмы - например, "взорлить" ( ского - от "зоря"). Если в ранних его стихах значительнур роль играрт темы вырождения, "искусственного рая", то позднее все более важное место начинает занимать у него противопоставление искусства и жизни:

$$
\begin{aligned}
& \text { СреАь шороха Аомов, средь кирпичей крылатых } \\
& \text { Я женщину живуо полюбил } \\
& \text { Я возненавияел Аух искусСтва... (с. 128) }
\end{aligned}
$$

Он бросает вызов бездушной иивилизации современности, искамарщей природу и человека:

Aа, я позт трагической забавы,

А все же жизнь смертельно хороша, Как буато женщина с линейными руками,

А не тлетворный куб из меди и стекла. (с. 120)

Со временем его смутное темное вдохновение все более проясняется, 
невнятица сменяется классической проясненностьо и светлыми тонами - однако не в ушерб сложному движенит мысли.

Несмотря на кажушуюся удаленность ватинова от русской позтической традиции и зкзотичность его вкусов, мы можем наметить некоторые ориентиры. Выше указывалосы на лермонтовские и пушкинские ноты в отдельных его произведениях. Но рядом с этой элегической тональностьо мы находим у него черты высокого одического строя. Так манера употреблать составные прилатательные типа "мрачноречивые", "смугломраморные" напоминарт стилистику старых русских переводов Гомера ("шлемоблещущий", "розоперстая"), Аержавина ("краезлатые"), вообще русский классицизм. Отметим, что подобные примеры попадаотся и у тотиева. Можно найти известное сходство ето поззии со стихами К. Батюшкова ("Последняя весна", "Подражания Аревним"), С Которым Он воОбще имеет много обще В. Кохельбекера (позма "Кассандра", стихотворение "луна"), В. Туманского. Особенно любопытно привести следуощее четверостишие малоизвестного позта Василия Григорьева из позмы "Князь Андрей Курбский'22:

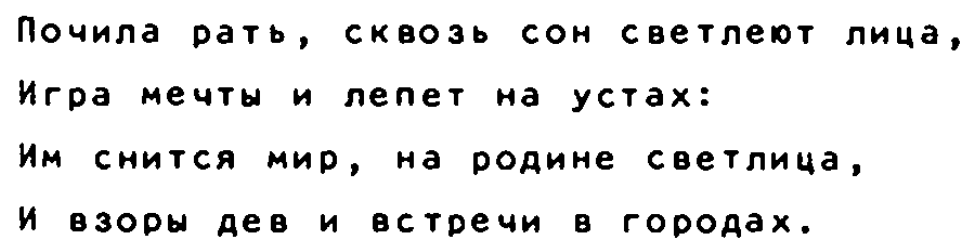

В литературе обынно связыварт его поззио с Хлебниковым и мандельштамом. Нам это кажется достаточно общим, - впрочем напомним, в дополнение к тому, что было уже сказано, что у последнего уме в 1920 roдy встречается почти "обзриутское" стихотворение "Феодосия". Приведем здесь и замечание Эм. Райса в его статье "0 40-летии русской поззии в СССР": "Разорванность и гиперболичность его душевной стихии напоминарт футуристов". $2 \hat{3}$ в самых ранних стихах Barинова есть сходство с "богоборческими" позмами С. Есенина "Инония" и "Иорданская голубица". Есть известное соприкосновение Barинова с позтами английского имажизма, такме охотно сопрягавшими античность с современностьр - например, трактовка образа өиломелы - соловья напоминает таковую у Т.С. Элиота. Это не кажется

\footnotetext{
22 "Невский альманах", С-Петербург 1830.

23 хурнал "Грани", 49, ФранкФурт 1961, с. 103.
} 
случайным, ибо в конце 20-х годов в Ленинграде подвизался английский поэт Ауглас Харман, знакомивший Вагинова с произведениями Элиота и Ажойса. Но разумеется, говоря о литературных корнях ВаГинова, надо Помнить О Том, Что Он владел латинским, Аревнегреческим, Французским, итальянским, испанским языками, что он работал над переводами "Дафниса и Хлои" Лонга (өместе с одним из членов Т.н. "кружка эллинистов" Анареем Егуновым), Анажело Полициано, Гонгоры, ценил александрийскуо поззию.

Из внутренне близких Вагинову позтов следует назвать в первуо очередь Бориса Поплавского, который, без сомнения, знал его стихи, доходившие до представителей Т.н. "парижской школы" (см. выwе отзывы Адамовича и Оиупа). Но здесь можно скореe говорить о конгениальности, ибо стиль Поплавского сложился независимо и иными путями. См. например у него:

$$
\begin{aligned}
& \text { Аух музшки мечтал в ночном саду } \\
& \text { С знигматической улшбкой соловьиной. }
\end{aligned}
$$

или :

$$
\text { Нет, молод я, так сумрачно, так долго. и пр. }
$$

На Западе поззия Вагинова неизвестна. Имеется лишь несколько переводов его на польский язык (В. Вирпша, И. Поступальский), ОАно раннее стихотворение было переведено на Французский язык В. Пястом, но в печати не появилось.

Отмечу в заключение, что я не ставил своей задачей всесторонний анализ поззии Вагинова - цель статьи заклочалась лишь в том, чтобШ СоПроводить возможно более Полный Свод его текстов необходимыми сведениями для понимания его творчества.

ת. Чертков 
УКАЗАТЕЛЬ СТИХОТВОРЕНИЙ К. ВАГИНОВА

Анахарзис . . . . . . . . . . . . . . . . . . . . . . . . . 147

Баллаda . . . . . . . . . . . . . . . . . . . . 201

Бегу в ночи. . . . . . . . . . . . . . . . . . . . . . . . . 81

Бегут тумана . . . . . . . . . . . . . . . . . . . . . . . . 21

B аду . . . . . . . . . . . . . . . . . . . . . . 208

В книговращалищах . . . . . . . . . . . . . . . . . . . . . 162

В нагорнах горнах . . . . . . . . . . . . . . . . . . . . . . 54

B odexc̄e . . . . . . . . . . . . . . . . . . . . . . . . . . 141

B пернатих облаках . . . . . . . . . . . . . . . . . . . . . 63

В повичеяном горе. . . . . . . . . . . . . . . . . . . . . . 194

В разноиветящем полумраке . . . . . . . . . . . . . . . . . . 100

В селеноях городских . . . . . . . . . . . . . . . . . . . . 126

B старинних запахаx. . . . . . . . . . . . . . . . . . . . . 32

В стремящейся стране . . . . . . . . . . . . . . . . . . . . 156

В тиии мочяой. . . . . . . . . . . . . . . . . . . . . 105

волизи от войн . . . . . . . . . . . . . . . . . . . . . . . 134

Beco mup nошел . . . . . . . . . . . . . . . . . . . . . . . 99

вихро, бей . . . . . . . . . . . . . . . . . . . . . . . . . 24

Война и голод . . . . . . . . . . . . . . . . . . . . . . 102

вороя . . . . . . . . . . . . . . . . . . . . . . . 152

Bсе xe \& л1оОль . . . . . . . . . . . . . . . . . . . 67

Вступил в Краму . . . . . . . . . . . . . . . . . . . . . 206

Всю ночо дома. . . . . . . . . . . . . . . . . . . . . . . 185

Bи римскоп дерхавкой . . . . . . . . . . . . . . . . . 88

вашел на Карповку. . . . . . . . . . . . . . . . . . . 62

Голос . . . . . . . . . . . . . . . . . . . . . . . 181

Да, иелай год . . . . . . . . . . . . . . . . . . . . . . . 150

Да, в позт . . . . . . . . . . . . . . . . . . . . . . . . 120

Деа пестрах одеяла . . . . . . . . . . . . . . . . . . . . . 164

Двенадиато долгих дней . . . . . . . . . . . . . . . . . . . 57

До $\operatorname{sлих~барханов~.~.~.~.~.~.~.~.~.~.~.~.~.~.~.~.~.~.~.~.~.~.~} 93$

Дрохал проспект . . . . . . . . . . . . . . . . . . . . . 170

Даханьем Ливии . . . . . . . . . . . . . . . . . . . . . . . 64

Eсто страняае кафз . . . . . . . . . . . . . . . . . . 35

Eсто странние ковра... . . . . . . . . . . . . . . . . . . . 34 
Eще зари оранхевое рханое . . . . . . . . . . . . . . . . . 79

Живу отшелоником . . . . . . . . . . . . . . . . . . . . . . 71

За годом год . . . . . . . . . . . . . . . . . . . . . . . . 200

За ночор ночо. . . . . . . . . . . . . . . . . . . . . 163

За осоку . . . . . . . . . . . . . . . . . . . . . . . . . . 41

Зарею луннов . . . . . . . . . . . . . . . . . . . . 157

3вукоподобиe . . . . . . . . . . . . . . . . . . . . 176

Звукопоӧобие проснулосо . . . . . . . . . . . . . . . . . . . 201

золотие глаза. . . . . . . . . . . . . . . . . . . . . . . . 184

Н все $x$ в не хивой . . . . . . . . . . . . . . . . . . . . . 74

Н zолай \& cmon. . . . . . . . . . . . . . . . . . . . . 75

Н оремлют лова . . . . . . . . . . . . . . . . . . . . . 108

H лирник спит. . . . . . . . . . . . . . . . . . . . . . . . 135

И ма по опустевшему паркету . . . . . . . . . . . . . . . . . 161

H пестрой . . . . . . . . . . . . . . . . . . . . . . . . . 129

Н снова мне. . . . . . . . . . . . . . . . . . . . . . . . 154

Н точно яблоки . . . . . . . . . . . . . . . . . . . . . . . 179

Н умер он. . . . . . . . . . . . . . . . . . . . . . . . 56

Нз хеновиднх слов . . . . . . . . . . . . . . . . . . . . . 139

Искусство . . . . . . . . . . . . . . . . . . . . . . . 82

Кахдий палеи . . . . . . . . . . . . . . . . . . . . . . . . 47

Kax бedp meoux . . . . . . . . . . . . . . . . . . . . . . . 31

"Как халь" . . . . . . . . . . . . . . . . . . . . . . 199

Как ночо бессоннуо .. . . . . . . . . . . . . . . . . . 203

Как нехен запах. . . . . . . . . . . . . . . . . . . . . . 29

Как хорошо под кипарисами . . . . . . . . . . . . . . . . . . 136

Какон прихотол . . . . . . . . . . . . . . . . . . . . . . . 135

Камин горит. . . . . . . . . . . . . . . . . . . . . . 52

Кафэ в переулке. . . . . . . . . . . . . . . . . . . . . . . 35

Кемтравами восходяm . . . . . . . . . . . . . . . . . . . . 191

Ногда ускули все . . . . . . . . . . . . . . . . . . . . . . 190

Крутам баком пересекая . . . . . . . . . . . . . . . . . . . 127

Ленинград . . . . . . . . . . . . . . . . . . . . . . 207

Лекинградская ночо . . . . . . . . . . . . . . . . . . . 100

Лишь шумят . . . . . . . . . . . . . . . . . . . . . 86

Луна, как глаз . . . . . . . . . . . . . . . . . . . . . 33

Любово опято томит . . . . . . . . . . . . . . . . . . . . . 55 
Любово страшна . . . . . . . . . . . . . . . . . . . 122

Любово - это вечная оносто . . . . . . . . . . . . . . . 158

мой бог гкилой . . . . . . . . . . . . . . . . . . . . . . . 73

мрак побелел . . . . . . . . . . . . . . . . . . . . 167

музака . . . . . . . . . . . . . . . . . . . . . . 162

ма все сосюкаем . . . . . . . . . . . . . . . . . . 171

Ma 3anada последкие осколки . . . . . . . . . . . . . . . . 90

ма здесо өдали . . . . . . . . . . . . . . . . . . . . . . . 37

Ma рохдена. . . . . . . . . . . . . . . . . . . . . . . 91

ма хмурие гости . . . . . . . . . . . . . . . . . . . . 40

Ma, эллияиста . . . . . . . . . . . . . . . . . . . . . . 166

На кришке гроба . . . . . . . . . . . . . . . . . . . . . 153

На маберехной . . . . . . . . . . . . . . . . . . . . . . . 31

На наберехной рассеет . . . . . . . . . . . . . . . . . . 186

На палубах Летучего Голландиа . . . . . . . . . . . . . . 38

Найухнут бубна. . . . . . . . . . . . . . . . . . . . . . 25

Над миром . . . . . . . . . . . . . . . . . . . . . . . . . 155

Надел Ксус . . . . . . . . . . . . . . . . . . . . . . . . . 23

Нам о оности . . . . . . . . . . . . . . . . . . . . . . . . 103

Намалил сердие . . . . . . . . . . . . . . . . . . . . . . 46

Нариисс . . . . . . . . . . . . . . . . . . . . . . . . . . 183

Не лазоревай дохдо.

Не лунному . . . . . . . . . . . . . . . . . . . . . . . .

Hе пестрою, но радостной . . . . . . . . . . . . . . . . . . 92

He muисо . . . . . . . . . . . . . . . . . . . . . . . . . . 148

Не человек. . . . . . . . . . . . . . . . . . . . . . . . . 130

Немного меда.. . . . . . . . . . . . . . . . . . . . . . . . 85

Нет, не любль закат . . . . . . . . . . . . . . . . . . . . 70

Нет, не расстался . . . . . . . . . . . . . . . . . . . 178

Но зиал я . . . . . . . . . . . . . . . . . . . . . . . . . 94

Норд-ост . . . . . . . . . . . . . . . . . . . . . . . . . . 205

Ночное поякство . . . . . . . . . . . . . . . . . . . 179

Ночь . . . . . . . . . . . . . . . . . . . . . . . . . 161

Ночь отгорела . . . . . . . . . . . . . . . . . . . . . . . 87

О, заверни в кояфетную . . . . . . . . . . . . . . . . . . . 79

О, сделай . . . . . . . . . . . . . . . . . . . . . 138

o, сколоко лет. . . . . . . . . . . . . . . . . . . . . . . 149 
O, удалимся . . . . . . . . . . . . . . . . . . . . . . . . . 28

обиватели . . . . . . . . . . . . . . . . . . . . . . . . . . 212

один бреду . . . . . . . . . . . . . . . . . . . . . . . . . 53

одик средо мгла. . . . . . . . . . . . . . . . . . . . . . . 132

одно керовное мгяовенье. . . . . . . . . . . . . . . . . . . 146

он думал . . . . . . . . . . . . . . . . . . . . . . . . . . 97

он не бал поян . . . . . . . . . . . . . . . . . . . . . . . 183

Oн разльбил себя . . . . . . . . . . . . . . . . . . . . . . 192

Oк с кахдам годом . . . . . . . . . . . . . . . . . . . . .

Oн с оностоп своей . . . . . . . . . . . . . . . . . . . . . 188

Onата соедияения слов... . . . . . . . . . . . . . . . . . . 119

Опято у окоя . . . . . . . . . . . . . . . . . . . . . . . . 51

Острова . . . . . . . . . . . . . . . . . . . . . . . . 28

Ocanлiт липа . . . . . . . . . . . . . . . . . . . . . . 89

Om берегов на берег... . . . . . . . . . . . . . . . . . 168

Omprвок . . . . . . . . . . . . . . . . . . . . . . 212

отшелояики . . . . . . . . . . . . . . . . . . . . . . . . .143

Палеи мой сияет. . . . . . . . . . . . . . . . . . . . . . . 59

Перевернул глаза . . . . . . . . . . . . . . . . . . . . . . 43

Пескя слов . . . . . . . . . . . . . . . . . . . . . . 171

Петербургские ночи . . . . . . . . . . . . . . . . . . . . . 42

Петербургский зөездочет . . . . . . . . . . . . . . . . . . . 64

Петербурхия . . . . . . . . . . . . . . . . . . . . . . . . . 40

Плавут в тарелке . . . . . . . . . . . . . . . . . . . . . 78

Под гром өойка . . . . . . . . . . . . . . . . . . . . . . . 133

Под лихолетьем одичалам. . . . . . . . . . . . . . . . . . . 140

Под пегим городом. . . . . . . . . . . . . . . . . . . . . . 20

Под рохоп . . . . . . . . . . . . . . . . . . . . . . . . 77

Под иудотворнам кехкам звоном. . . . . . . . . . . . . . . . 147

Подделки . . . . . . . . . . . . . . . . . . . . . . . . . . 204

Покрал, прикрал . . . . . . . . . . . . . . . . . . . . . . . 50

Помно последнол ночо . . . . . . . . . . . . . . . . . . . . 68

Почуествовал он боль . . . . . . . . . . . . . . . . . . . 202

Поззия есть дар. . . . . . . . . . . . . . . . . . . . . . . 142

Позма . . . . . . . . . . . . . . . . . . . • . . . . . . . . 211

Позма көадратов . . . . . . . . . . . . . . . . . . . . . . . 120

Пред разноиветнол толпоп . . . . . . . . . . . . . . . . . . 96 
Пред Революиией громадной . . . . . . . . . . . . . . . . . 189

Прекрасен, как ворон . . . . . . . . . . . . . . . . 152

Прекрасен мир . . . . . . . . . . . . . . . . . . . . . 193

Промозглай Питер . . . . . . . . . . . . . . . . . . . . . . 207

Проспехта целятся . . . . . . . . . . . . . . . . . . 106

Психея (Л1000во - это вечная оность). . . . . . . . . . . . 158

Психея (Cnит орачяий пир) . . . . . . . . . . . . . . . . . 137

Психея дияная . . . . . . . . . . . . . . . . . . . . . . . 182

Путешествие в хаос . . . . . . . . . . . . . . . . . . . . . 17

Русалка пела... . . . . . . . . . . . . . . . . . . 187

С Актиохией . . . . . . . . . . . . . . . . . . . . . 45

Сегодня - дхра. . . . . . . . . . . . . . . . . . . 30

Седой maбук . . . . . . . . . . . . . . . . . . . . . . . 18

Cидит она . . . . . . . . . . . . . . . . . . . . . . 80

Cлова из пепла. . . . . . . . . . . . . . . . . . . . . 175

Cпит sрачнай nup... . . . . . . . . . . . . . . . . . . . . 137

Cnum в рескицах . . . . . . . . . . . . . . . . . . . . . . 48

Среди кочнах . . . . . . . . . . . . . . . . . . . . . . . 123

Стали улиия узкими . . . . . . . . . . . . . . . . . . . . . 66

Столича глядела . . . . . . . . . . . . . . . . . . . . . . 181

Самам Нева . . . . . . . . . . . . . . . . . . . . . . . . . 69

тает маятник. . . . . . . . . . . . . . . . . . . . . . . 27

тают дома . . . . . . . . . . . . . . . . . . . . . . . . . 104

Тебе примерещился . . . . . . . . . . . . . . . . . . . . 159

Темнеет море . . . . . . . . . . . . . . . . . . . . . . 61

Тасяиа девятосот двадиато пятай год

у милих ног . . . . . . . . . . . . . . . . . . . . . . . . 44

у mрубнах горл . . . . . . . . . . . . . . . . . . . . . . . 128

ух дено краснеет . . . . . . . . . . . . . . . . . . . . 197

ух сизий дам. . . . . . . . . . . . . . . . . . . . . . . . 26

украшение берегов .. . . . . . . . . . . . . . . . 106

умолкнет ли . . . . . . . . . . . . . . . . . . . . . 39

упала ночо... . . . . . . . . . . . . . . . . . . . . 49

усталосто о теле. . . . . . . . . . . . . . . . . . . . . 72

хотел он... . . . . . . . . . . . . . . . . . . . 196

Lеema uв emym . . . . . . . . . . . . . . . . . . . . . . . . 22

yac om yacy . . . . . . . . . . . . . . . . . . 95 
Черкеет ночо . . . . . . . . . . . . . . . . . . . . . . 60

Черно бескомечкое утро . . . . . . . . . . . . . . . . . . . 177

Шумит Pодос . . . . . . . . . . . . . . . . . . . . . . . . 124

Эвридика . . . . . . . . . . . . . . . . . . . . . . . . . . 157

Элликиста . . . . . . . . . . . . . . . . . . . . 166

Охкая ночо. . . . . . . . . . . . . . . . . . . . . 203

Окоша . . . . . . . . . . . . . . . . . . . . . . . . 209

Я воплотил . . . . . . . . . . . . . . . . . . . . . . . . . 131

Я восполненоя ке искал . . . . . . . . . . . . . . . . . . . 160

Я естал, пошативаясо. . . . . . . . . . . . . . . . . . . 58

Я звезди не люблю . . . . . . . . . . . . . . . . . . . . 82

Я польбил . . . . . . . . . . . . . . . . . . . . . . . . . 125

Я променял . . . . . . . . . . . . . . . . . . . . . . . 84

я скял сапог . . . . . . . . . . . . . . . . . . . . . . . . 83

я стал просвечивающей формой . . . . . . . . . . . . . . . . 98 


\section{ARBEITEN UND TEXTE ZUR SLAVISTIK HERAUSGEGEBEN VON WOLFGANGKASACK}

1 Sabine Appel: Jurij Oleša. "Zavist" und "Zagovor čuvstv". Ein Vergleich des Romans mit seiner dramatisierten Fassung. 1973. 234 S. DM 24.-

2 Renate Menge-Verbeeck: Nullsuffix und Nullsuffigierung im Russischen. Zur Theorie der Wortbildung. 1973. IV, $178 \mathrm{~S}$. DM 18.-

3 Jozef Mistrik: Exakte Typologie von Texten. 1973. $157 \mathrm{~s}$. DM 18.-

4 Andrea Hermann: Zum Deutschlandbild der nichtmarxistischen Sozialisten. Analyse der Zeitschrift "Russkoe Bogatstvo" von 1880 bis 1904. 1974. 198 S. DM 20.-

5 Aleksandr Vvedenskij: Izbrannoe. Herausgegeben und eingeleitet von Wolfgang Kasack. 1974. 116 S. DM 15.-

6 Volker Levin: Das Groteske in Michail Bulgakovs Prosa mit einem Exkurs zu A. Sinjavskij. 1975. 158 S. DM 18.-

7 Геннадия АЯги: Стихи 1954 - 1971. Редакция и вступительная статья В. Казака. 1975. 214 S. DM 20.-

8 Владимир Казаков: Ошибка живых. Роман. 1976. 201 5. DM 20.-

9 Hans-Joachim Dreyer: Petr Veršigora. "Ljudi s čistoj sovest'ju". Veränderungen eines Partisanenromans unter dem EinfluB der Politik. 1976. 101 S. DM 15.-

10 николая Эрдман: Мандат. Пьеса в трех деяствиях. Редакция и вступительная статья В. Казака. 1976. 109 S. DM 15.-

11 Karl-Dieter van Ackern: Bulat Okudžava und die kritische Literatur über den Krieg. 1976. 196 S. DM 20.-

12 Михаил Булгаков: Ранняя неизданная проза. Составление и предисловие Ф. Левнна. 1976. 215 S. DM 24.-

13 Eva-Marie Fiedler-stolz: ol'ga Berggol'c. Aspekte ihres lyrischen Werkes. 1977. 207 S. DM 20.-

14 Christine Scholle: Das Duell in der russischen Literatur. Wandlungen und Verfall eines Ritus.1977. 194 S. DM 20.-

$M$ u $n c h$ e $n$. Verlag $o t t o s$ a $g$ e $r$ in Kommission 
ARBEITEN UND TEXTE ZUR SLAVISTIK HERAUSGEGEBEN VON WOLFGANG KASACK

15 Aleksandr Vvedenskij: Minin i Požarskij. Herausgegeben von Felix Philipp Ingold. Vorwort von Bertram Müller. 1978. 49 S. DM 8.-

16 Irmgard Lorenz: Russische Jagdterminologie. Analyse des Sprachgebrauchs der Jäger. 1978. 558 S. DM 60.-

17 Владимир Казаков: Случарныи воин. Стихотворения 1961 - 1976. Поэмы. Драмы. Очерк > Зудесник<. 1978. 214 S. DM 24.-

18 Angela Martini: Erzähltechniken Leonid Nikolaevič Andreevs. 1978. 322 S. DM 30.-

19 Bertram Müller: Absurde Literatur in RuBland. Entstehung und Entwicklung. 1978. 210 S. DM 24.-

20 Михаил Булгаков: Ранняя несобранная проза. Составление Ф. Левина и Л.в. Светина. Предисловие Ф. Левина. 1978. 250 S. DM 30.-

21 Die Russische Orthodoxe Kirche in der Gegenwart. Beiträge zu einem Symposium der Deutschen Gesellschaft für Osteuropakunde. Herausgegeben von Wolfgang Kasack. 1979. 86 S. DM 10.-

22 Георгия Оболдуев: Устоичивое неравновесье. Стихи 1923 - 1949. Составление и подготовка текста А.Н. Терезина. Предисловие А.Н. Терезина. Послесловие В. Казака. 1979, 176 S. DM 20.-

23 Wolfgang Kasack: Die russische Literatur 1945 - 1976. Mit einem Verzeichnis der Ubersetzungen ins Deutsche 1945 - 1979. 1980. 72 S. DM 10.-

24 Михаил Булгаков: Ранняя неизвестная проза. Составление и предисловие Ф. Левина. 1981. 254 S. DM 32.-

25 Поэт-переводчик Константин Богатырев. Друг немецкой литературы. Ред.-сост. В. Казак с участием Л. Копелева и Е. Эткинда. 1982. 316 S. DM $34 .-$

26 Константин Вагинов: Собрание стихотворения. Составление, послесловие и примечания Л. Черткова. Предисловие В. Каэака. 1982. 240 S. DM 26.-

$M \ddot{u} n c h e n$. Verlag $O t t \circ \quad S$ a $g$ e $r$ in Kommission 